Ianni Régia Scarcelli

\title{
O MOVIMENTO ANTIMANICOMIAL E A REDE SUBSTITUTIVA EM SAÚDE MENTAL: a experiência do município de São Paulo 1989 - 1992
}

\author{
Dissertação apresentada ao Instituto de \\ Psicologia da Universidade de São Paulo, como \\ parte dos requisitos para a obtenção do título \\ de Mestre em Psicologia. \\ Área de concentração: Psicologia Social. \\ Orientadora: Profa. Dra. Maria Inês Assumpção Fernandes
}




\section{FICHA CATALOGRÁFICA}

Scarcelli, Ianni Regia

O movimento antimanicomial e a rede substitutiva em saúde mental: a experiência do município de São Paulo 1989 - 1992./Ianni Régia Scarcelli. São Paulo, 1998. 149 pp.

Dissertação (Mestrado) - Instituto de Psicologia da Universidade de São Paulo. Departamento de Psicologia Social e do Trabalho.

Orientadora: Maria Inês Assumpção Fernandes.

1. Saude mental 2. Pichon-Rivière, Enrique, 1907 3. Psicologia social 4. Distúrbios mentais 5. Pessoal de asúde mental 6. Hospitais psiquiátricos 7. Movimentos sociais. 
À minha mãe Elza (in memoriam)

Ao meu pai Devanir

Para o meu filho Gabriel. 


\title{
AGRADECIMENTOS
}

\section{Maria Inês Assumpção Fernandes}

orientadora, mestra e grande amiga presente em todas as horas

\section{Duarte Pereira}

pelas sugestões e provocações sempre muito estimulantes

Nacile Daud Jr.

pelas informações, documentos, livros, reportagens, sugestões, que gentilmente colocou a minha disposição nos últimos 4 anos

\section{Luiza E. Faustinone}

pela revisão do texto, 'dicas’ de escrita e, principalmente, pela dedicada atenção

\section{Marinalva Santos Gil} Maria Cecília R. Freitas

pela paciência e disponibilidade em responder às minhas tantas perguntas

\section{À equipe do LAPSO:}

Ismênia, Cris, Denise, Edna, Eliane, Lucila, Mirna pela torcida, apoio e presença amiga

Aos amigos, colegas de trabalho, de curso e de Movimento e às minhas irmãs

que, de alguma forma, acompanharam e estimularam essa trajetória

\section{Rui Rogério Constantino Barbosa}

companheiro e colaborador nos diferentes momentos deste trabalho

\author{
Ao CNPQ
}

pelo apoio financeiro 
SCARCELLI, I. R. O movimento antimanicomial e a rede substitutiva em saúde mental: a experiência do município de São Paulo (1989 - 1992). São Paulo, 1998, (149 pp.). Dissertação de Mestrado apresentada ao Instituto de Psicologia da Universidade de São Paulo.

\section{RESUMO}

O presente trabalho tem por objetivo refletir sobre a atuação/inserção dos trabalhadores em saúde mental na implantação da rede substitutiva de saúde mental do município de São Paulo, entre os anos de 1989 e 1992.

A discussão, orientada pelas contribuições da Psicologia Social como descrita por Pichon-Rivière, apoia-se em dados coletados a partir da observação grupos de supervisão clínica/institucional. Estes grupos são parte do Projeto de Formação Permanente em Recursos Humanos na Área de Saúde Mental, resultado do convênio entre a Prefeitura do Município de São Paulo e a Universidade de São Paulo (PMSP/USP), através do termo aditivo entre Secretaria Municipal de Saúde e Instituto de Psicologia (SMS/PST-IPUSP), cuja realização se deu paralelamente à implantação da rede referida.

Ressignificar e construir/superar limites conceituais, teóricos, técnicos, práticos; e problematizar as contradições, conflitos e dúvidas decorrentes da prática são fundamentais na substituição de práticas antimanicomiais.

Ao enfocar a contradição entre saberes e práticas do modelo psiquiátrico tradicional X modelo antimanicomial, analisou-se os conflitos de natureza objetiva e/ou subjetiva, emergentes no contexto de trabalho e relacionados principalmente à concepção de loucura, constituição da equipe multiprofissional e formação dos trabalhadores em saúde mental na construção de práticas inspiradas nos princípios antimanicomiais. Constatou-se que contradições ('loucura/doença mental x saúde mental', 'loucura/desrazão X razão', 'anormalidade/patologia $\mathrm{x}$ normalidade', 'saber $\mathrm{X}$ não saber', 'modelo médico $\mathrm{X}$ não médico', 'terapêutico $\mathrm{X}$ não terapêutico') provenientes da quebra do modelo manicomial desencadeiam processos de indiscriminação, emergentes nas relações intersubjetivas, tendo como efeito a perda de limites ('trabalhadores $\mathrm{X}$ usuários', 'técnicos $\mathrm{X}$ não técnicos', 'neurose X psicose’, 'eficiência X ineficiência’ de técnicas, 'público X privado). Assim, a construção destes novos modelos, ligada a desconstrução do manicômio, apresenta-se como uma tarefa complexa, cuja realização não se restringe ao âmbito das práticas, pois carrega consigo contradições inerentes ao sistema social do qual advém (burguesia X proletariado, movimentos sociais $X$ Estado, sociedade global $X$ instituição de saúde, instituição $X$ trabalhadores, trabalhadores em saúde mental $\mathrm{X}$ usuário/familiares e usuários $\mathrm{X}$ familiares). 
SCARCELLI, I. R. The anti-asylum movement and the proposal of a new model for menthal health care: the experience of the municipality of São Paulo (1989 -1992). São Paulo, 1998 (149 pp). Dissertation for Master Degree present to Instituto de Psicologia da Universidade de São Paulo.

\section{ABSTRACT}

The aim of the present study is to analyse the performance of mental health workers in the implementation of a new model of mental health care is the municipality of São Paulo, in the years 1989 to 1992.

This study is based on data collected from the observation of groups of clinical/institutional supervision and is guided by the contributions of the Social Psychology as proposed by Pichon-Rivière. These groups were part of a Project for Continued Education in Human Resources in the Mental Health Area, agreed between the Municipality of São Paulo and the University of São Paulo (PMSP/USP), through the Municipal Health Secretarial and the Institute of Psychology (SMS/PST-IPUSP). The Project was developed at the same time as a new model for mental health care was implemented.

An analyses indicate that to substitute the asylum practice it's essential to give a new meaning to conceptual, theoretical, technical and practical limits and to bring to discussion the contradictions, conflicts and doubts which emerge in action.

Focusing the contradiction between knowledge and practice in the traditional psychiatric model and in the anti-asylum model, we analysed the objective/subjective conflict emerging in the context of work and related mainly to the conception of madnees, the building-up of a multiprofessional team and the education of mental health workers in the developement of a practice based on the anti-asylum principles. Our findings show that the contradictions (madness/meltal illness X mental health, madness/unreason X reason, abnormality/pathology X normality, knowledge X non-knowledge, medical X non medical model, therapeutic $\mathrm{X}$ non therapeutic) that result from the break of the asylum model foster a process of indiscrimination emerging in the inter subjective relationship and have the effect of loss of limits (workers $\mathrm{X}$ users, techinician X non-tecnician, neurosis $\mathrm{X}$ psychosis, efficiency $\mathrm{X}$ inefficiency of techiniques, public $\mathrm{X}$ private).

Thus the construction of these new model, linked to the 'disconstruction' of an asylum model, is a complexe task that cannot be restricted to the bounds of practice, since it has contradiction which are inherente to the social system from which it derives (bourgeoisie $\mathrm{X}$ workers, social movements $\mathrm{X}$ state, global society $\mathrm{X}$ health institution, institution $\mathrm{X}$ workers, workers in mental health $\mathrm{X}$ users/family and users $\mathrm{X}$ family). 




\section{CAPÍTULO 1}

MOVIMENTOS SOCIAIS E REFORMA PSIQUIÁTRICA BRASILEIRA....

1.1 - Sobre a emergência de novos Movimentos na década de 9

70

1.1.1 - A reforma sanitária e psiquiátrica no âmbito do Estado.......................... 12

1.2 - Movimento de trabalhadores em saúde mental no contexto da reforma psiquiátrica: "pela descontrução do aparato

manicomial”.....

1.3 - Movimento de luta antimanicomial: "por uma sociedade sem manicômios”.....

1.3.1 - Algumas considerações sobre o MLA.

\section{CAPÍTULO 2}

MODELOS DE ATENÇÃO EM SAÚDE MENTAL:

A EXPERIÊNCIA PAULISTA..

2.1 - Do preventivismo à descontrução: inventando novas práticas em saúde mental

2.2 - Construindo uma rede substitutiva: a experiência paulistana

2.2.1 - Algumas considerações sobre o modelo paulistano.

\section{CAPÍTULO 3}

A PESQUISA

3.1 - O projeto de formação na área de saúde mental.

3.1.1 - Sobre o processo de investigação sistemática

3.1.2 - Considerações sobre a prática de supervisão nos serviços de saúde mental da rede pública.

3.2 - O referencial teórico

3.3 - O percurso de análise. 


\section{CAPÍTULO 4}

UM OLHAR SOBRE A REDE SUBSTITUTIVA:

OS INTERSTÍCIOS DA PRÁTICA......................................................................... 76

4.1 - A concepção de loucura no trato ao doente mental.......................................... 77

4.2 - A equipe multiprofissional: emblema da convivência dos diferentes.............. 89

4.3 - A formação dos trabalhadores em saúde mental.............................................. 102

4.4 - A construção de novas práticas e os ideais antimanicomiais............................. 113



REFERÊNCIAS BIBLIOGRÁFICAS........................................................................... 143 


\section{INTRODUÇÃO}

Substituir práticas manicomiais tem sido lema de centenas de trabalhadores em saúde mental no Brasil. "Modelos substitutivos aos manicômios", "práticas alternativas em saúde mental”, "tratamento humanizado ao paciente psiquiátrico", resguardadas as devidas

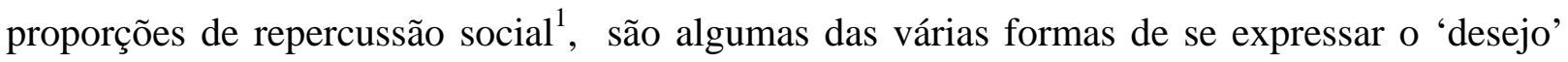
por mudanças no trato do portador de sofrimento mental.

Nosso objetivo, neste estudo, será refletir sobre o tipo de atuação/inserção desses trabalhadores no processo de implantação de um modelo de atenção em saúde mental, que se pretende substitutivo do modelo psiquiátrico tradicional.

Nosso trabalho se dará a partir do entendimento de que modelos substitutivos dizem respeito à construção de práticas alternativas inspiradas nos princípios antimanicomiais. Tais princípios orientam ideais, idéias e práticas que se colocam como opositoras às formas de violência e exclusão presentes em vários tipos de relações, principalmente nas institucionais, que se estabelecem em nossa sociedade. O manicomial, nesse sentido, é entendido como metáfora de relações de violência e discriminação, geradoras de exclusão social, sendo a instituição psiquiátrica considerada como emblemática, por representar uma das formas violentas de opressão.

Diante disso, as práticas alternativas buscam se contrapor àquelas institucionalizadas há séculos e que mantêm ou servem de sustentáculo à estrutura econômica e política das sociedades que vivenciaram o processo de industrialização capitalista. Tais práticas apresentam-se como alternativas às das escolas, creches, presídios, instituições de saúde e outras instituições que têm, na maioria das vezes, características de "instituições totais", no sentido dado por Goffman ${ }^{2}$ : como um lugar onde alguns grupos de pessoas são condicionados por outras pessoas sem terem nenhuma possibilidade de escolher seu modo de viver, estando à

\footnotetext{
${ }^{1}$ Estamos diante de diferentes âmbitos de aspirações, pois apesar do consenso sobre a forma desumana de tratar o portador de sofrimento mental, a postura dos trabalhadores em saúde mental, enquanto sujeitos, varia de ações pontuais ( atendimento clínico mais humano) a propostas de mudanças socias, seja estas mudanças à estrutura de atenção hospitalocêntrica, incluindo a crítica a ideologia do normal/patológico, seja a transformações estururais de sociedades capitalistas, por sua vez responsabilizadas pela fabricação de um contingente de excluídos que não servem ao seu sistema de produção.
} 
mercê do controle, do julgamento e dos planos de outro, sem poderem intervir para modificar o andamento e o sentido da instituição.

Consideramos que as primeiras possibilidades concretas de transformação do sistema psiquiátrico tradicional no Brasil surgiram, principalmente, a partir das organizações de parte desses trabalhadores que atuavam na rede pública. Tais organizações alcançaram, em vários momentos, posição de destaque social e ao ganharem aliados de diferentes setores da sociedade, passaram a ditar tendências, a partir de uma postura crítica, e a forçar novas posturas dos representantes governamentais.

É assim que a partir do início da década de 80, alguns governos estaduais e municipais começam a contratar um número relevante de profissionais de diferente formação universitária para comporem equipes de saúde mental dentro do sistema público de saúde. Psicólogos, psiquiatras, assistentes sociais, enfermeiros, terapeutas ocupacionais, fonoaudiólogos etc., integram instituições, como unidades básicas de saúde, e participam da implantação de novos equipamentos, como ambulatórios de saúde mental, centros de atenção psicossocial, hospitais dia, centros de convivência e cooperativas etc.

O contingente de trabalhadores em saúde mental amplia-se nos serviços e, conseqüentemente, diferentes concepções compõem o cotidiano das instituições e do processo de instalação dos programas de saúde mental proposto pelos governantes.

Tais concepções dizem respeito a diferentes âmbitos: político, técnico ou da própria história pessoal dos sujeitos envolvidos. O tipo de formação universitária dos profissionais, provenientes de áreas do conhecimento que vão das ciências biológicas e médicas até as ciências sociais, pode ser considerado determinante na compreensão de questões relacionadas ao processo saúde-doença. Além disso, o entendimento sobre a forma de inserção no processo de trabalho bem como a postura frente à população atendida nos serviços públicos podem ser referidos à história de vida desses trabalhadores, determinante de suas singularidades. Essas diferenças vão construindo o novo contexto de implantação.

Nesse processo, reconhecemos os trabalhadores como protagonistas. Se as condições materiais e institucionais estiverem condizentes com os objetivos do trabalho, as práticas irão se concretizar (ou não), principalmente pelo seu tipo de inserção, pela sua disposição a iniciativas, pelo seu espírito de criação associados à sua formação.

Ao considerá-los protagonistas dessa história, estamos buscando resgatar sua dimensão de sujeito produzido em uma práxis. "Nele não há nada que não seja resultante da interação entre indivíduo, grupos e classes”. ${ }^{3}$ Desse modo, o 'sucesso' ou o 'fracasso' na consolidação das práticas antimanicomiais é produto da superação (ou não) das contradições resultantes dessa interação.

\footnotetext{
${ }^{2}$ GOFFMAN, E. Manicômios, Prisões e Conventos. São Paulo, Ed. Perspectiva, 1979.

${ }^{3}$ PICHON-RIVIÈRE, E. O Processo Grupal. São Paulo, Ed. Martins Fontes, 1986, p. 174.
} 
Enfim, essa nova tarefa exige trabalhadores-sujeitos empenhados na sua concretização. Mas ao voltarmos nossa atenção aos trabalhadores/sujeito buscamos, na medida do possível, não perder de vista contradições e questões inerentes a este processo que dizem respeito ao âmbito político e institucional.

Nesse sentido, buscamos considerar neste trabalho a constituição do Movimento de Trabalhadores em Saúde Mental, que ao se ampliar enquanto princípios - hospício como emblema das relações manicomiais - e novos segmentos da sociedade civil - usuários e seus familiares - passa a ser chamado Movimento de Luta Antimanicomial.

Os movimentos sociais travam discussões e ações de reivindicação, denúncia, formulação de principios naquilo que diz respeito ao âmbito político e que terá reflexos, seja de forma imediata ou mediata, positiva ou negativa, no cotidiano de trabalho. Consideramos também relevante destacar outro ponto definidor de especificidades nessa construção: a crítica à psiquiatria moderna e a busca por novas formas de relação/intervenção.

As práticas substitutivas ou alternativas dizem respeito a um campo de trabalho que apresenta especificidade e um grau de complexidade que expressam características muito próprias para sua implantação. Várias correntes de reforma psiquiátrica internacionais inspiram o movimento antimanicomial e orientam a proposição de novos modelos de atenção em saúde mental, mas não configuram certezas.

De acordo com Birman e Costa, "não estamos absolutamente diante de um sistema teórico seguro e consistente que pudéssemos colocar entre parênteses temporariamente, a fim de discutirmos a constituição de uma melhor rede assistencial. Estamos perante um problema que necessita ser tratado teoricamente, pois dele decorrem conseqüências de base sobre a organização de instituições voltadas para a assistência." A 'nova psiquiatria' que se constitui crítica à estrutura tradicional do hospital psiquiátrico é considerada problemática e ambígua enquanto construção teórica. Segundo os autores, ela muda o enfoque de seu objeto de tratamento da doença à promoção de saúde mental, do mesmo modo que o local privilegiado de intervenção e aplicação de terapêuticas são deslocados da instituição para a comunidade. Assim, a grande característica da psiquiatria atual é seu ‘estatuto de crise’ em todos seus níveis constitutivos. ${ }^{5}$ É exatamente essa psiquiatria que serve de base para a construção das práticas.

Dentro desse contexto, a forma de trabalho que se destaca, e que pode ser entendida como um dos pilares da constituição de práticas, privilegia a atuação em equipe com profissionais de diferente formação, ou seja, a equipe multiprofissional. Esta pressupõe que a circulação de diferentes conhecimentos e concepções de mundo pode gerar novas possibilidades

\footnotetext{
${ }^{4}$ BIRMAN, J.; COSTA, J.F. Organização de instituições para uma psiquiatria comunitária. In AMARANTE, P. Psiquiatria Social e Reforma Psiquiátrica. Rio de Janeiro. Editora FIOCRUZ, 1994, p. 41.

${ }^{5}$ Ibidem. No trecho citado os autores estão se referindo à Psiquiatria Comunitária, para posteriormente inseri-la no contexto da atual psiquiatria. No entanto, consideramos que tal insegurança de terreno teórico diz respeito também ao estatuto de crise no qual se constitui a psiquiatria atual.
} 
de intervenção. Em outros termos, pressupõe a necessidade da convivência de diferentes pontos de vista, técnicos e políticos, o que nos remete mais uma vez aos ideais do movimento antimanicomial.

Essa forma de atuação, ao nosso ver, além de estar colocada como princípio fundamental no trabalho para a implantação de novos modelos de atenção à saúde, está também presente no cotidiano dos trabalhadores como discurso, como prática e também como 'desejo' de que possa se concretizar, seja através do investimento da administração pública na sua constituição, seja pela operacionalização do seu funcionamento, o que dependeria principalmente de seus componentes.

A partir dessa consideração, vamos entendê-la como emblemática das relações estabelecidas seja no dia-a-dia das instituições, seja na organização dos movimentos antimanicomiais, por circular como ideal nos dois tipos de discurso. Emblemática ao idealizar a convivência das diferenças que possibilitariam a criação do "novo" no trato à doença mental. Essa convivência seria expressa, de um lado, entre profissionais com formação diversa na prática dos serviços e, de outro lado, aglutinaria profissionais, usuários, familiares, lideranças sindicais e representantes de diferentes movimentos sociais na organização e constituição do próprio Movimento. Representaria, nos dois âmbitos, a esperança de transformação das práticas em saúde mental, a partir da ampliação nas formas de intervenção à saúde, ao mesmo tempo em que denunciaria os limites desta intervenção deteminados pelas condições econômica, sociais e politicas que as sustentam e à própria conceituação da loucura/doença mental derivada dos marcos referenciais críticos à psiquiatria clássica.

Abordar a construção de novas práticas sob o ponto de vista da inserção dos trabalhadores é um tema complexo e, antes de mais nada, consideramos relevante situar o seu lugar nesse contexto. Dessa forma, optamos por discutir no primeiro capítulo deste trabalho, "Movimentos Sociais e Reforma Psiquiátrica Brasileira”, um apanhado histórico da organização do movimento antimanicomial no Brasil, destacando seus princípios e situando-o no contexto do movimento pela reforma sanitária e psiquiátrica brasileira.

Outro motivo que nos faz trazer alguns aspectos dessa história está relacionado à nossa experiência entre os trabalhadores em saúde e nos movimentos sociais. Essa convivência nos tem mostrado em diversas ocasiões, uma ausência de memória dos envolvidos nesses processos.

A história de inserção dos trabalhadores em saúde de um lado e, de outro, sua organização em movimentos sociais, tem sido permeada por conquistas e derrotas, avanços e retrocessos. Nesse contexto o 'fazer' tem ocupado lugar de detaque, deixando-se em segundo plano, na maioria das vezes, a atividade reflexiva voltada para a sistematização dos saberes constituídos. Dessa forma, a história parece estar sempre se iniciando, ou seja, muito do que já foi construído não é acumulado e se perde no processo. Os sujeitos aparecem como 
descartáveis, não se percebem escrevendo a história e não reconhecem sua própria experiência como relevante.

No sentido de resgatar experiências que fazem essa história e ao mesmo tempo considerando alguns aspectos dos marcos referenciais que as fundamentaram, abordaremos no segundo capítulo, “Os Modelos de Atenção em Saúde Mental - a Experiência de São Paulo”, algumas das práticas desenvolvidas no Estado de São Paulo, a partir de 1982, destacando a experiência da capital paulista, por ser esta, o nosso objeto de investigação.

No terceiro capítulo, "A Pesquisa”, discorreremos sobre nosso método de trabalho. A coleta de dados se deu no segundo semestre de 1992, durante a realização do Projeto de Formação Permanente em Recursos Humanos na Área de Saúde Mental. Tal Projeto foi elaborado para apoiar a implantação da rede substitutiva ao modelo psiquiátrico hospitalocêntrico no município de São Paulo, entre os anos de 1989 e 1992. Durante um semestre, pudemos acompanhar grupos de supervisão clínico-institucional formado por profissionais de diferente formação universitária, trabalhando em diferentes equipamentos que compunham tal rede. A inclusão de auxiliares de pesquisa, como observadores, nesses grupos gerou o material analisado neste trabalho.

A análise dos dados, desenvolvida no quarto capítulo, "Um olhar sobre a rede substitutiva: os interstícios da prática”, foi orientada, principalmente, pelas contribuições da Psicologia Social, formulada por Pichon-Rivière. Nesta, direcionamos nosso olhar para os conflitos emergentes de contradições entre modelo antimanicomial e modelo psiquiátrico tradicional no contexto de implantação das novas práticas.

Nossa intenção nesta pesquisa, ao destacar a reflexão sobre o tipo de atuação/inserção de trabalhadores no processo de implantação da rede substitutiva, justifica-se por entendermos que nas novas propostas de atenção em saúde mental, a subjetividade dos envolvidos nesse processo de construção é matéria prima do próprio trabalho. Dessa forma, a construção de práticas alternativas passaria pela ressignificação de representações que dizem respeito principalmente à loucura/doença mental, ao potencial criador no trabalho, à identidade profissional na convivência com a “equipe” e na relação com os principais interessados neste processo, os usuários das instituições.

Nesse sentido, tendo como cenário a organização do movimento antimanicomial, lançamos as seguintes indagações:

- como os trabalhadores assimilam, interpretam e recriam nas práticas as idéias veiculadas sobre a construção das novas práticas e/ou produzem idéias a partir da sua própria prática?

- quais seriam os efeitos do discurso sobre a loucura e formas de intervenção sobre os sujeitos/trabalhadores envolvidos neste cenário e as ressonâncias das possíveis 
transformações ocorridas nesses mesmos sujeitos para a construção dessa trajetória de implantação?

Nossas perguntas se direcionam para problematizar questões, sistematizar temas e situações que circulam no cotidiano de trabalho, esperando assim trazer algumas contribuições que possam vir a fazer parte do referencial dos envolvidos no processo de reestruturação de atenção em saúde mental - como indagação ou revelação - e dos princípios que estão para além do atendimento assistencial. Contribuições que possam trazer também novos elementos a serem incluídos nas definições das políticas públicas, seja na construção de novos modelos, seja na formação dos atuais e futuros trabalhadores em saúde mental. 


\section{1 - MOVIMENTOS SOCIAIS E REFORMA PSIQUIÁTRICA BRASILEIRA}

Neste capítulo, interessa-nos abordar aspectos históricos da reforma psiquiátrica brasileira destacando a organização de um dos movimentos sociais que surgiu no Brasil, a partir de meados da década de 70: o Movimento de Trabalhadores em Saúde Mental - MTSM.

A organização dos movimentos sociais, ao lado da reorganização de partidos políticos, sindicatos e associações, marcaram um novo momento político de luta por liberdade, igualdade e democracia da sociedade brasileira e de repúdio ao regime autoritário instalado no país a partir de 1964. "Um amplo debate perpassou a sociedade como um todo, no qual a possibilidade de reverter as enormes desigualdade sociais e a extrema extensão da pobreza se traduziu em propostas políticas que se centraram na redefinição de políticas sociais.” 6

Considerando que os problemas decorrentes das desigualdades sociais provocam a fragilização sistemática das condições e dos modos de vida de segmentos sociais diversos, e destes podem emergir formas organizadas de militância com caráter reivindicativo, entendemos os movimentos sociais como conjunto de diferentes tipos de associações relacionadas à formação de identidades coletivas que se sustentam em laços de solidariedade. Tais laços originam-se das péssimas condições de vida das populações excluídas do acesso aos direitos básicos - moradia, trabalho, transporte, saúde, educação etc. - ou daquelas que têm ameaçadas sua modalidade de vida - meio ambiente, violência, discriminação de minorias, pauperização de setores profissionais etc. ${ }^{7}$

“Os movimentos articulam-se (em diferentes níveis e com amplitude diversa) em função de uma ou várias reivindicações coletivas que são definidas a partir da percepção de carências comuns (que vão desde a ausência de asfalto ao sentimento de um tratamento discriminatório ao nível das relações sociais em seu conjunto). É a carência que define a coletividade possível, dentro da qual se constitui a coletividade efetiva dos participantes do movimento. Como as carências podem ser definidas de diferentes modos em diferentes níveis, os movimentos sociais constituem formas muito flexíveis de mobilização, que operam 'cortes' muito diversos uns dos outros, definindo coletividades de tipo muito diferentes (desde 'as

6 GERSCHMAN, S. A democracia inconclusa: um estudo da reforma sanitária brasileira. Rio de Janeiro, Ed. Fiocruz, 1995, p.41.

7 Ibidem, p.187 
mulheres' 'os homossexuais' ou 'os negros', até 'os moradores de rua', 'os freqüentadores de um parque público' ou 'os usuários de um serviço’.” 8

A partir da constituição de uma identidade coletiva, estes movimentos lutam, no campo social, por questões que vão desde a instalação de um processo democrático e a criação de direitos políticos e civis à transformação radical da sociedade. As noções de igualdade e liberdade constituem pólos de referência nessa idéia de democracia.

O fato de buscarem esta identidade não significa, porém, que eles sejam monolíticos, podendo ser pensados como "processos, abertos, sujeitos a contradições internas e pautados por uma composição heterogênea que potencializa a emergência de diferentes formas de ação coletiva e de interação e/ou negação em face do Estado.” 9

Para Durham, tais movimentos apresentam uma realidade paradoxal, pois ao mesmo tempo em que se caracterizam pela heterogeneidade, do ponto de vista das classes sociais, enfatizam a igualdade nas suas relações internas e no plano simbólico.

“A heterogeneidade e a desigualdade tornam-se elementos constitutivos da vida urbana que são extraordinariamente exacerbados nas metrópoles latino-americanas. Fazem parte, portanto, da experiência de vida mais imediata da população e penetram inelutavelmente nos próprios movimentos sociais. É importante investigar, então, esse processo de criação interna de uma igualdade (mítica?) que se consubstancia na categoria comunidade, termo esse que permeia todo o discurso produzido pelos movimentos sociais. Podemos dizer que a construção dessa igualdade se dá através de uma negatividade específica. Vimos que os movimentos se articulam pela formulação de uma carência coletiva. Os indivíduos mais diversos tornam-se iguais na medida que sofrem a mesma carência. A igualdade da carência recobre a heterogeneidade das positividades (dos bens, das capacidades, do trabalho, dos recurso culturais). No movimento, face à mesma carência, todos se tornam iguais.”10

Essa relação igualdade $\mathrm{X}$ heterogeneidade imprime modalidades próprias à organização dos movimentos sociais e, no âmbito das relações intersubjetivas estabelecidas entre seus membros, pode se manifestar em forma de conflitos, os quais, muitas vezes, são traduzidos como problemas de ordem pessoal de um ou outro participante.

Sob esse ponto de vista, é possível considerarmos as seguintes questões que podem emergir no processo de convivência coletiva: como incluir nesse contexto as diferenças individuais sem que estas impeçam a convivência? Como criar um projeto coletivo sem que sua concretização implique a anulação das subjetividades? Enfim, como tornar possível a expressão das singularidades na construção de um projeto coletivo?

\footnotetext{
8 DURHAM, E. Movimentos sociais: a construção da cidadania. Novos Estudos, Cebrap, São Paulo, 10, out. 84, p. 27.

9 JACOBI, P. Movimentos sociais e políticas públicas. São Paulo, Cortez, 1993, p.16.

${ }^{10}$ DURHAM, E.R. Op cit., 1984, p.28.
} 
Tais questões estarão presentes no decorrer deste trabalho, tanto no que diz respeito à organização dos movimentos relacionados à saúde, em prol de uma reforma psiquiátrica e/ou sanitária brasileira, quanto na construção de práticas institucionais advindas destes movimentos.

\section{1 - Sobre a emergência de novos Movimentos na década de 70}

O início dos anos 70 no Brasil é marcado como o período do milagre econômico. Época em que se vende a imagem de progresso, de bem-estar e, ao mesmo tempo, momento em que mais se tortura e se persegue aqueles que se opõem ao regime de opressão instalado a partir do golpe de 64. São os "anos mais terríveis de perseguições, torturas, seqüestros, assassinatos, desaparecimentos contra os que se opunham aos modelos então vigentes. Desde os modelos ligados ao sistema em geral até aqueles como os de família, o sexual, o de estudante, o de jovem etc."11

A partir da instalação do regime autoritário pelas forças armadas brasileiras, o Estado, assentado num modelo capitalista, monopolista e dependente, passa a ocupar o lugar de centralizador das decisões políticas.

Apesar do real crescimento econômico desencadeado neste período, não há o mesmo desenvolvimento na área social. Ao contrário, há a intensificação do processo de pauperização de grande maioria da população brasileira.

"No Brasil pós-64, a posição das políticas sociais no contexto das prioridades governamentais caracteriza-se pela implementação de um novo conceito de eficiência no qual os interesses econômicos prevalecem sobre os interesses sociais. Como reflexo disto, as políticas governamentais nas áreas de bem-estar coletivo - saúde pública, saneamento, educação, habitação e nutrição - têm pequeno destaque na agenda governamental, ou são objeto de formulações com caráter discutível, como é o caso mais explícito da política habitacional e previdenciária. Deste modo, não se altera significativamente perfil de desigualdades sociais dominante, o que, somando à compressão salarial e ao desemprego, configura um crescente agravamento das condições gerais da população.” 12

Tais condições de precariedade se faziam visíveis conforme documento apresentado pelo Centro Brasileiro de Estudos de Saúde - CEBES no I Simpósio sobre Política Nacional de Saúde na Câmara Federal (1979):

\section{"É praticamente consensual entre os especialistas o diagnóstico de} que, a partir da década de 60, vem piorando gradativamente o nível de vida da

11 COIMBRA, M.B. Gerentes da Ordem: Algumas Práticas "Psi” nos anos 70 no Brasil. São Paulo. Tese (Doutorado), Instituto de Psicologia da USP, 1992, p. 53. 
população. Aumentaram significativamente a mortalidade infantil, as doenças endêmicas, as taxas de acidentes do trabalho, o número de doentes mentais etc. Pioraram, igualmente, as condições de saneamento, a poluição ambiental e os níveis nutricionais chegaram ao ponto de preocupar as autoridades, hoje um tanto pessimistas com relação ao que chamam de 'miséria absoluta'."13

Em virtude dessa pauperização e das demandas dela decorrentes, diretamente relacionadas à pouca efetividade social advinda das políticas governamentais, o regime instalado no pós-64 é colocado em risco quanto a sua legalidade. "Com a crescente perda da legitimidade do regime autoritário, emerge com maior nitidez essa tensão no aparelho estatal, que busca novos mecanismos de articulação e intervenção a partir de pressupostos pautados pela construção de uma nova institucionalidade política que recoloca as relações entre Estado e demandas sociais.” 14

É nessa conjuntura que começam emergir formas de organização que buscam se contrapor ao sistema vigente. "Novos espaços públicos estão sendo construídos, onde o cotidiano - com toda a sua ambigüidade - ocupa, em muitos momentos, o lugar de resistência , de produção singular, de algo novo e criativo.”15

Muitas das manifestações públicas emergentes, a partir do início dos anos 70, representam a concretização dos esforços de várias frentes e segmentos sociais envolvidos na luta contra o regime militar.

D. Paulo Evaristo Arns, por exemplo, ao ser nomeado arcebispo de São Paulo no início da década, torna públicas as denúncias contra atos de torturas praticados nas prisões paulistas. As organizações e partidos políticos de esquerda, condenados à clandestinidade pelo regime, os setores progressistas da Igreja, as Comunidades Eclesiais de Base, as associações de bairro etc. conclamam por mudanças sociais.

Nesta conjuntura e com influências desses diferentes segmentos começa a emergir uma série de novos movimentos. Destacamos, nos anos de 1975/76, entre outros, o Movimento de Saúde da Zona Leste, o Movimento do Custo de Vida, o Movimento Contra a Carestia. Ainda neste período toma corpo no país a luta pela anistia geral, ampla e irrestrita.

Ao Movimento Paulista de Saúde da Zona Leste ligam-se médicos sanitaristas que passam a desenvolver palestras, visitas, pesquisas, cursos. Em 1977, conseguem organizar as primeiras comissões de saúde na região. No ano de 1978, o Movimento consegue que os Conselhos de Saúde, eleitos pelos moradores, sejam constituídos oficialmente. ${ }^{16}$

12 JACOBI, P. Op cit., 1993, p. 9.

${ }^{13}$ CEBES. A questão democrática na área da saúde. Revista Saúde em Debate, no 9.

14 JACOBI, P. Op cit., 1993, p.9.

${ }^{15}$ COIMBRA, M.C. B. Op cit., 1992, p. 87.

${ }^{16}$ Ibidem. 
Nos anos seguintes (78 a 80) destaca-se a revitalização do movimento sindical, culminando em grandes greves realizadas pelos metalúrgicos de São Paulo, ABC paulista, Belo Horizonte etc. A organização destes trabalhadores desempenha papel relevante no processo de redemocratização em processo no país.

Ao final da década de 70 e com influências das iniciativas populares destes dez anos, ganham amplitude os movimentos sociais organizados em torno de temas de saúde: movimento sanitário, movimento popular de saúde, movimento médico e também o MTSM.

O debate político colocado nesses movimentos ultrapassa o âmbito de questões relativas à reformulação dos sistemas de saúde. Além de discussões de temas gerais ligados ao processo de redemocratização, à melhoria das condições de vida dos trabalhadores, inclui outras relativas à sua própria organização e às formas possíveis de sua relação com o Estado (autonomia X institucionalização, entre outras). No que diz respeito ao MTSM podemos destacar, além destas, outras preocupações relacionadas ao papel normalizador das instituições e a desinstitucionalização, as quais vão lhe dar uma especificidade. Tais questões expressam uma das diferenças existentes entre os movimentos em torno da reforma psiquiátrica e aqueles da reforma sanitária.

Embora o movimento pela reforma psiquiátrica tenha parte de suas origens relacionadas ao movimento sanitário, em sua trajetória terá momentos de aproximação com este e outros de afastamento.

\subsection{1 - Reforma Sanitária e Psiquiátrica no âmbito do Estado}

A proposta de reformulação política e de atuação no campo da saúde, denominada Reforma Sanitária, segundo Westphal ${ }^{17}$, pode ser entendida como "um projeto ideológico nascido na sociedade civil e fundamentado em movimentos sociais empenhados na ampliação dos direitos de cidadania”, que já vinha sendo pensada no Brasil desde 1955. A partir de meados da década de 70, sob liderança intelectual e política do movimento sanitário, delineia-se um novo momento nesta história.

A formação de um pensamento crítico-reflexivo relativo às questões de saúde, o desenvolvimento de novos programas nessa área, a difusão ideológica de uma consciência sanitária estão em processamento, principalmente dentro das Universidades, apesar de toda adversidade enfrentada diante do regime político da época.

Como parte do projeto de modernização do Estado, idealizada pelo governo militar, a Reforma Universitária, implantada a partir de 1969, passa a imprimir um caráter 
autoritário e tecnicista a estas instituições. Dentre as resoluções da reforma, nas Faculdade de Medicina são criados os Departamentos de Medicina Preventiva, inspirados no modelo de saúde comunitária americano.

Nestes Departamentos passam a se alojar muitos dos sanitaristas provenientes do movimento sanitário. Mesmo sem os recursos e apoios oficiais, são produzidos na Universidade novos conhecimentos e experiências que se opõem ao modelo privatista hegemônico de assistência, financiado pela Previdência Social.

O Ministério da Previdência e Assistência Social tinha como política a priorização da compra de serviços dos hospitais privados, a partir de credenciamentos e convênios. Essa política privatizante, apesar de expressar um discurso voltado para a melhoria da assistência médica à população, produziu excessos de atos médicos, alguns corretos e outros abusivos e fraudulentos, os quais ocasionaram déficit nos cofres da Previdência. Além disso, contrariava o modelo de saúde pública por priorizar ações puramente assistenciais desvinculadas das propostas de prevenção.

No caso da atenção psiquiátrica, a política privatizante da Previdência facilitou a construção e ampliação de um grande número de hospitais psiquiátricos privados, fato que contrariava as recomendações da Organização Mundial de Saúde, que preconizava a concentração da assistência psiquiátrica no nível ambulatorial. Havia no Brasil no ano de 1961, 135 hospitais psiquiátricos; em 1971, 341; e em 1981, $430 .^{18}$

Na contra-corrente desse modelo hegemônico, temas como regionalização, hierarquização, democratização dos serviços pela participação popular etc., fazem parte das discussões no meio universitário. As novas experiências e idéias daí decorrentes extrapolam os limites institucionais para se somarem e/ou desencadearem um movimento mais amplo, cujas reivindicações por mudanças não dizem respeito apenas ao modelo de atenção à saúde.

Consideramos que a expressão destas tendências contra-hegemônicas são reveladoras de contradições inerentes à própria estrutura do Estado capitalista.

Jacobi ${ }^{19}$ aponta que se "é inegável que o Estado capitalista expressa os interesses das classes hegemônicas, não se pode negar que também se configura como condensação de uma relação de forças sociais, expressando portanto as contradições das classes. ... O Estado assume o papel de articulador e organizador da sociedade, independente de sua condição de suporte de certas relações de dominação, adotando o papel de fiador de relações sociais.” No entanto, este papel articulador vai até um ponto em que não haja mudanças estruturais deste sistema capitalista.

\footnotetext{
17 WESTPHAL, M, F. Participação Popular e Políticas Municipais de Saúde: Cotia e Vargem Grande Paulista. Tese (Livre Docência) - Departamento de Práticas de Saúde Pública da Faculdade de Saúde Pública da Universidade de São Paulo, 1992, p.2.

18 ALVES, D.S.N. et.al. Elementos para uma análise da assistência em Saúde Mental no Brasil. Brasília, mimeo, 1992.

19 JACOBI, P. Op cit, 1993, p.4.
} 
Para Coutinho ${ }^{20}$, a realização dos direitos sociais numa sociedade capitalista pode ser comparada aos limites análogos aos dos salários pagos aos trabalhadores, ou seja, “não se pode ampliar o nível de satisfação das demandas sociais além do ponto em que tal ampliação impeça a reprodução do capital global; mas, em contrapartida, não se pode reduzir esse nível de satisfação abaixo do limite mínimo (entendido também no sentido histórico-moral) a não ser que se rompam as regras consensuais que fundamentam uma ordem política.”

A manutenção de regras consensuais, aparentemente representativa de interesses plurais da sociedade, convém ao Estado, desde que estas não ‘desvirtuem’ a essência do projeto político da classe detentora dos meios de produção. A concessão de reivindicações referentes às demanda sociais, por exemplo, pode representar formas de mascarar contradições e impedir o acirramento de classes, cujos interesses são opostos. Em contrapartida, tais concessões podem também fortalecer os setores envolvidos na luta política e social externa ao aparato do Estado e, conseqüentemente, a emergência de novas contradições.

Considerando o projeto de modernização do Estado com influências do modelo americano, podemos encontrar no âmbito do governo militar, no auge da ditadura, discursos e propostas voltadas para o setor saúde, aparentemente progressistas.

Já no final da década 60, propostas de reformulação de políticas de Saúde Mental elaboradas pela Divisão de Saúde Mental do Ministério da Saúde - DINSAM faziam parte do contexto institucional do governo. Alguns documentos produzidos pelo Ministério emitiam opiniões críticas referentes à situação da assistência psiquiátrica brasileira. O ministério da Saúde numa publicação denominada Política Nacional de Saúde, 1973, reconhecia que:

“1. O sistema assistencial brasileiro, baseado na solução custodial, que consiste na internação em massa, dos pacientes em hospitais psiquiátricos, está inteiramente superado, pois seu abandono vem sendo preconizado há cerca de trinta anos;

2. As internações em hospitais psiquiátricos do país são feitas, em proporção apreciável, de modo indiscriminado, sem a devida triagem especializada;

3. As despesas com hospitais psiquiátricos alcançam $90 \%$ dos custos operacionais totais, havendo Estados que não utilizam recursos em Serviços extra-hospitalares." 21

Encontros e congressos de caráter oficial ${ }^{22}$ foram realizados ao final da década de 60 até meados de 70, e deliberaram resoluções conflituosas que reconheciam a necessidade

20 COUTINHO, C. N. Representação de interesses, formulação de políticas e hegemonia. In TEIXEIRA, S.F. Reforma Sanitária - em busca de uma teoria. São Paulo, Ed. Cortez, 1989, p.56/57.

${ }^{21}$ BRASIL, Ministério da Saúde. Política Nacional da Saúde, Brasília, 1973; apud CEBES. Saúde em Debate, 10, São Paulo. 
da Saúde Mental ser integrada à Saúde Pública, baseada nos princípios da Psiquiatria Comunitária e, ao mesmo tempo, defendiam o lugar do hospital psiquiátrico como empresa privada e sua expansão às custas dos seus próprios lucros. ${ }^{23}$

No ano de 1970, durante a realização do I Congresso Brasileiro de Psiquiatria, o Ministro da Saúde Mário Machado pronuncia uma "Declaração de Princípios de Saúde Mental”. Nela, reconhece que: a Assistência em Saúde Mental é responsabilidade da sociedade; os serviços de Saúde Mental devem ser integrados à rede de recursos da comunidade; os hospitais devem ser reestruturados e promover a reintegração social do indivíduo; e o desenvolvimento de um programa de formação voltado para as equipes terapêuticas multiprofissionais. $^{24}$

No âmbito do governo, é lançada em 1971, a primeira versão do Manual de Assistência Psiquiátrica, com referencial preventivo-comunitário. Neste mesmo ano, o governo do Estado de São Paulo, sintônico com os acontecimentos no âmbito federal instituiu o Grupo de Trabalho voltado para a "reformulação total da assistência aos doentes mentais". ${ }^{25}$ Dentre as proposições do grupo produzidas em relatório destaca-se a criação de Centros Comunitários de Saúde Mental, sendo, para isto, indispensável a integração de Faculdades de Medicina em tal projeto. Instala-se um grupo executivo, responsável pela implantação de tal programa. Nesse sentido, em 1973 são instituídos convênios celebrados entre a Coordenadoria de Saúde Mental da Secretaria Estadual de Saúde e órgãos de ensino e pesquisa públicos e privados ${ }^{26}$, resultando na criação de dezessete instituições (centros de saúde mental da comunidade) voltadas para atividades relacionadas à assistência à comunidade, formação de profissionais técnicos e pesquisa de modelos de atuação alternativos.

A instalação dos convênios vem acompanhada de uma série de resistências internas no âmbito governamental, relacionadas ao modelo comunitário, contraditório à política privatizante hegemônica. No decorrer do processo, a formulação original da proposta passa a ser descaracterizada. ${ }^{27}$

Em 1974, a partir do âmbito federal, foi lançada a terceira versão do Manual de Assistência Psiquiátrica, que, juntamente com os outros manuais, teve "importante influência no pensamento crítico nacional, assim como na formação do campo ideológico público em

22 Entre estes: Ata de Porto Alegre, 1967, I Conferência sobre Saúde Mental nas Américas em San Antonio no Texas, 1968; Reunião de Viña Del Mar no Chile, 1968. Vide ROSA, A.C. Saúde Mental Comunitária: Análise Dialética de um Movimento Alternativo. São Paulo. Dissertação (Mestrado). Instituto de Psicologia da USP, 1987.

${ }^{23}$ ROSA, A. C. Op cit., 1987.

${ }^{24}$ Ibidem.

25 Diário Oficial do Estado (30/06/71) apud ROSA, op cit, p.167

${ }^{26}$ Dentre estes podemos destacar Faculdades de Medicinas da USP, UNICAMP, Santa Casa, OSEC, PUC, Faculdades de Saúde Pública e Enfermagem da USP.

27 São enfatizadas ações voltadas para aumentar o número de atendimentos ambulatoriais em detrimento das atividades preventivas e de pesquisa. A liberação de verbas para pagamento dos serviços se dava fora dos prazos, implicando freqüentes atrasos dos salários e conseqüentemente alta rotatividade de profissionais. ROSA, A.C., Op. cit., 1987, p. 181/182. 
saúde mental”, mas sua aplicação efetiva não aconteceu, na medida em que os recursos da Previdência Social foram destinados prioritariamente "à compra de serviços privados (fundamentalmente hospitalares), e esses, por sua força política, não acataram as instruções normativas do INPS.” 28

Apesar de tais 'iniciativas' de caráter preventivista e comunitário advindas da Previdência Social e do Ministério da Saúde, o processo de desenvolvimento do setor privado asilar se fortalece ainda mais, a partir da criação do Plano de Pronta Ação (1974). Este representa a consolidação da privatização da assistência médica no âmbito da Previdência Social e a intensa proliferação de hospitais psiquiátricos privados contratados por este setor.

Entretanto, ainda neste mesmo ano, são destinadas Bolsas de Saúde Mental para alunos do Curso Integrado em Saúde Mental, cujo objetivo era formar técnicos para as unidades hospitalares da DINSAM. Este curso, segundo Amarante, é um instrumento relevante de formação de pessoal, priorizando questões relacionadas ao desenvolvimento do serviço público de saúde e das práticas institucionais em Saúde Mental. Porém, dois anos passados, tais bolsas passam a ser utilizadas como forma de recompor a falta de pessoal das unidades hospitalares.

No ano de 1977, o Ministério da Saúde apresenta as "Diretrizes Programáticas em Saúde Mental”, que lançam o Plano Integrado em Saúde Mental - PISAM. Este busca concretizar uma política de saúde mental preventivista em significativa parte do país. O programa, desenvolvido principalmente nos estados da região Norte e Nordeste, “é relativamente bem implantado, mas os resultados são bastante questionados, com pouco ou nenhum impacto na atenção ao problemas de saúde mental, quando não ocorre a 'produção de novas demandas', sem a resposta, por exemplo, aos egressos da rede hospitalar ou atenção aos chamados pacientes 'crônicos' ${ }^{29}$ Em pouco tempo o plano, defendido pelos partidários de uma política pública de saúde mental, entra em processo de desativação e recebe duras críticas de segmentos do próprio Ministério da Saúde comprometidos com a psiquiatria biológica e/ou com o setor privado.

Em 1978, a DINSAM, sediada no Rio de Janeiro, entra em crise a partir do surgimento de denúncias de seus hospitais, que são seguidas por um movimento de greve. Deste resulta a demissão de um grande número de profissionais e estagiários, tendo esta uma grande repercussão na imprensa. A partir desse fato, a circulação de questões referentes à assistência psiquiátrica amplia-se para espaços além do âmbito da saúde.

Desse fato, podemos supor que, apesar das ações voltadas referentes a um plano de atenção em saúde mental, público, nunca terem sido priorizadas, até mesmo por não representarem propostas hegemônicas no âmbito do governo, houve um aumento do contingente de profissionais ligados ao trabalho em saúde mental.

${ }^{28}$ AMARANTE, P. Loucos pela vida: a trajetória da reforma psiquiátrica no Brasil. Rio de Janeiro, SDE/ENP, 1995, p.108 
Assim, tanto a implantação de programas como os Convênios de 73 e o PISAM, a destinação de bolsas para formação de profissionais da DINSAM, quanto o aumento vertiginoso do número de leitos psiquiátricos e construção de novos hospitais privados, resultaram na contratação de muitos profissionais, mesmo que estes não tenham permanecido nestes postos por muito tempo, seja pela desativação de programas, seja pela demissão daqueles que não compactuavam com o tipo de 'assistência' dada aos doentes mentais. Neste sentido, esse novo cenário é composto por profissionais submetidos tanto ao trabalho sem remuneração devido ao descaso governamental, como às condições indignas de maus tratos destinadas aos pacientes internados nos hospícios.

Tal situação, vinculada a outras emergentes no país, passaram a estar relacionadas à reivindicação pelos direitos humanos, defesa dos serviços públicos, melhores condições de trabalho, investimento em políticas sociais e detonavam um processo que já vinha sendo fermentado em função de tantas atrocidades cometidas pelo Estado brasileiro nesta época. O surgimento do Movimento de Trabalhadores em Saúde Mental, no final da década, soma-se a outras manifestações que vinham emergindo de vários segmentos da sociedade civil.

\section{2 - Movimento de Trabalhadores em Saúde Mental no contexto da reforma psiquiátrica: "pela desconstrução do aparato manicomial”}

O MTSM pode ser considerado o principal desencadeador do movimento pela reforma psiquiátrica no Brasil que ganha amplitude a partir do final da década de 70. Fizeram parte do movimento de reforma diferentes entidades e instituições, tais como a Associação Brasileira de Psiquiatria - ABP, Federação Brasileira de Hospitais - FBH, as indústrias farmacêuticas, as universidades, e o Estado através de seus órgãos do setor saúde (Ministério da Saúde e Ministério da Previdência e Assistência Social). Entretanto, foram os trabalhadores em saúde mental, a partir de sua organização enquanto movimento social, que tiveram destaque nesse processo, imprimindo-lhe um novo momento ao elaborarem propostas de reformulação do sistema assistencial e ao desenvolverem um pensamento crítico em relação ao saber psiquiátrico. $^{30}$

“O Movimento dos Trabalhadores em Saúde Mental é o ator sujeito político privilegiado na conceituação, divulgação, mobilização e implantação das práticas transformadoras. É no seio do MTSM que se funda um exercício regular e sistemático de

\footnotetext{
${ }^{29}$ Ibidem.

30 Os aspectos considerados nesse tópico são fundamentados fundamentalmente no estudo desenvolvido por AMARANTE em Loucos pela vida: a trajetória da reforma psiquiátrica brasileira
} 
reflexão e crítica ao status quo psiquiátrico e de onde surgem ainda as propostas teóricas e a práxis de uma nova política de saúde mental. O movimento, contudo não é uma organização unitária, homogênea, monolítica; assim, mais correto seria falar em movimentos, no sentido mesmo de algo que se move, que se transmuta e que possui diferentes facetas." 31

A constituição do MTSM se deu a partir da articulação de trabalhadores de diferentes locais de inserção, tais como os núcleos estaduais de Saúde Mental do Centro Brasileiro de Estudos de Saúde - CEBES $S^{32}$, as comissões de Saúde Mental dos Sindicatos dos Médicos, o Movimento de Renovação Médica - REME, a Rede de Alternativas à Psiquiatria. ${ }^{33}$ Seu objetivo "é constituir-se em espaço de luta não institucional, em locus de debate e encaminhamento de propostas de transformação da assistência psiquiátrica, que aglutina informações, organiza encontro, reúne trabalhadores em saúde, associações de classe, bem como entidades e setores mais amplos da sociedade" ${ }^{34}$

Para Amarante, o movimento pela reforma psiquiátrica brasileira teve como estopim a “crise da DINSAM”, no ano de 1978, desencadeada a partir da deflagração de uma greve de estagiários e profissionais que trabalhavam nos hospitais desse órgão do Ministério da Saúde, a qual é seguida de demissão de duzentos e sessenta grevistas. As denúncias, que vinham se tornando freqüentes, diziam respeito às condições precárias a que estavam submetidos tanto pacientes internados (mortes não esclarecidas, estupro, agressão física) quanto profissionais, estando ambos envoltos num clima de ameaças e violências.

Tais fatos têm grande repercussão na imprensa e ocupam lugar nos noticiários dos meios de comunicação durante oito meses. Nesse período sucederam-se reuniões periódicas em grupos, comissões, assembléias, sindicatos e demais entidades da sociedade civil. Nesse movimento são organizados os núcleos de saúde mental do CEBES e do Sindicato dos Médicos. Vários eventos são organizados no sentido de impedir que essas questões desaparecessem da pauta da imprensa e das instituições.

Em outubro desse mesmo ano surge a oportunidade para a organização dos movimentos de trabalhadores que vinham sendo desenvolvidos em alguns Estados a partir da realização do V Congresso Brasileiro de Psiquiatria em Camboriu, Santa Catarina. Tal evento foi denominado "Congresso da Abertura”, pois pela primeira vez os movimentos em saúde mental participaram de um encontro organizado pela Associação Brasileira de Psiquiatria, que até então aglutinava setores considerados conservadores em relação à reforma psiquiátrica.

\footnotetext{
31 AMARANTE, Paulo. Op cit, p. 113.

32 O Centro Brasileiro de Estudos de Saúde - CEBES foi constituído em 1976 como espaço de organização e produção do pensamento crítico em saúde, possibilitando a estruturação de bases políticas para as reformas sanitária e psiquiátrica. Outros espaços de discussão já vinham ocorrendo no momento de sua fundação, entre estes, os das Comunidades Eclesiais de Base e os Sindicatos de Trabalhadores do ABCD.

33 Rede de Alternativas em Psiquiatria: movimento internacional criado em 1974, Bruxelas, por nomes representativos do movimento de antipsiquiatria, da psiquiatria democrática italiana e da psiquiatria de setor.

34 AMARANTE, P. Op cit., 1995, p. 58.
} 
O congresso, previsto para ser um encontro científico, teve um caráter de discussão e organização político-ideológica relacionado ao campo da saúde mental, bem como à formulação de críticas ao regime político nacional. Dentre as resoluções do Congresso é possível destacar pontos que explicitam a linha de atuação que seria adotada pelo MTSM: aprovação de moções repudiando a privatização do setor saúde e outras apoiando as organizações representativas livres e também a “anistia ampla, geral e irrestrita.”

No mesmo mês de outubro acontece o I Congresso Brasileiro de psicanálise de Grupos e Instituições. A realização deste possibilita a vinda ao Brasil dos principais mentores da Rede Internacional de Alternativas à Psiquiatria, do movimento da Psiquiatria Democrática Italiana, da Antipsiquiatria; dentre estes, Franco Basaglia, Felix Guattari, Robert Castel, Erwing Goffman. Deste congresso sucederam-se encontros e conferências com a presença de tais conferencistas, ampliando-se o debate em torno de um referencial crítico sobre o saber médicopsiquiátrico e a natureza das instituições.

O CEBES teve um papel significativo nesse momento ao apoiar conferências em universidades, sindicatos e associações com a presença de Basaglia, que passou a representar uma influência importante na conformação do pensamento crítico do MTSM.

Nos anos 1979 e 1980, vários congressos e encontros realizados contaram com a presença de representantes do MTSM ${ }^{35}$, o que possibilitou o aprofundamento de discussões referentes aos problemas sociais relacionados à doença mental, política nacional de saúde mental, condições de trabalho, privatização da medicina, denúncias de barbaridades ocorridas nas instituições psiquiátricas; bem como a emergência de novos temas sobre legislação penal, civil e direitos do doente mental.

As discussões geradas pelo MTSM começam a ter repercussão também dentro de estruturas partidárias. A partir de 1981, trabalhadores em saúde mental, militantes do recém fundado Partido dos Trabalhadores, organizam o Grupo de Saúde Mental do PT - buscando produzir “uma resposta partidária” referente às "necessidades de saúde mental da população”. ${ }^{36}$ Encontros de Trabalhadores em Saúde Mental do PT do Estado de São Paulo são realizados e neles se priorizam debates relacionados à crise social e loucura, bem como a promover uma “reflexão crítica” sobre a política de saúde mental que vinha sendo desenvolvida pelo governo estadual do Partido do Movimento Democrático Brasileiro - PMDB, a partir de 1982.

As discussões de âmbito partidário passam a fazer parte dos fóruns de organização dos trabalhadores do movimento geral. Um documento produzido pelo Grupo de Saúde Mental do PT indicava:

\footnotetext{
35 Podemos destacar: I Congresso Nacional dos Trabalhadores em Saúde Mental no Instituto Sedes Sapientiae, III Congresso Mineiro de Psiquiatria, II Encontro Nacional de Trabalhadores de Saúde Mental. Além destes encontros, em 1979 o CEBES apresenta no I Simpósio de Política de Saúde da Câmara dos Deputados, a formulação original do Sistema Único de Saúde, precursora do atual texto constitucional, também um dos primeiros documentos de análise e denúncia da Política de Saúde Mental de repercussão nacional neste período: "A assistência Psiquiátrica no Brasil - Setores Públicos e Privados.”
} 
"Para evitar que haja desvios na formulação de suas diretrizes, o grupo pretende ter uma ligação estreita com os movimentos sociais, particularmente os movimentos Populares e Sindicais de Saúde; por atuação direta ou através das organizações de base do Partido. Por outro lado, esta íntima relação com os movimentos Sociais vai permitir uma contínua revitalização do Grupo. 37

A época de realização dos Encontros de âmbito partidário acima referido, é coincidente com um momento da reforma psiquiátrica brasileira, chamado por Amarante de trajetória sanitarista.

Este autor sugere que um dos modos de visualizar tal processo de reforma pode ser feito a partir de uma periodização composta por trajetórias, já que estas dizem respeito a percursos e caminhos que muitas vezes se cruzam e se sobrepõem. Desse modo, seria possível identificar três trajetórias a partir do final da década de 70: a alternativa, a sanitarista e a de desinstitucionalização.

A 'trajetória alternativa' coincide com o momento em que se assiste ao final do período de milagre econômico, com o conseqüente processo pela abertura democrática. Nesse momento "são plantadas as bases para a reorganização dos partidos políticos, dos sindicatos, das associações e demais movimentos e entidades da sociedade civil.” 38

O início da década de 80 é associado ao momento da 'trajetória sanitarista', quando parte significativa dos militantes pela reforma sanitária e psiquiátrica é assimilada ao aparelho de Estado. Esta incorporação se deu, "por um lado, de tática desenvolvida inicialmente do movimento sanitário, de ocupação dos espaços públicos de poder e de tomada de decisão como forma de introduzir mudanças no sistema de saúde, num momento em que, com o fim da ditadura, se renovam as lideranças da tecnoburocracia; por outro, se constitui como proveniente de outra tática, essa da iniciativa do Estado, de absorver o pensamento e o pessoal crítico em seu interior, com o objetivo de seja alcançar legitimidade, seja reduzir os problemas agravados com a adoção de uma política de saúde excessivamente privatizante, custosa e elitista.” ${ }^{39}$

Este é um momento institucionalizante dos movimentos por reformas que contam com o apoio ou participação significativa de segmentos do movimento sanitário e do MTSM.

A partir de 1985, parte significativa dos postos de chefia de programas estaduais e municipais de saúde mental são ocupados por fundadores e ativistas do MTSM. Uma série de

\footnotetext{
${ }^{36}$ GRUPO DE SAÚDE MENTAL DO PT - SP O PT e a Crise de Saúde Mental. São Paulo, mimeo, 1984.

${ }^{37}$ Ibidem.

${ }^{38}$ AMARANTE, P. Op. cit., 1995, p. 94.

39 AMARANTE, P. Op. cit., 1995, p. 95.
} 
encontros $^{40}$, a maioria de caráter oficial, se sucedem nesse período com participação ou apoio destes ativistas.

Dentre estes destacamos o I e o II Congresso de Trabalhadores em Saúde Mental do Estado de São Paulo, respectivamente nos anos de 1985 e 1986.

O I Congresso teve um caráter oficial e estava voltado para discussão e implementação de propostas no âmbito da secretaria estadual de saúde. Sua organização se deu por parte dos gerentes estatais e nesta não foi incluída a participação de trabalhadores. A política na área de saúde mental desenvolvida pelo governo do Estado não vinha agradando os trabalhadores, os quais têm seus ânimos acirrados ao se depararem com um congresso para trabalhadores em cuja organização não puderam opinar e participar.

Durante o evento de abertura, após terem sido proferidos os discursos das autoridades presentes, “centenas de trabalhadores ergueram-se de suas cadeiras e enunciaram coletivamente um protesto no qual expressaram uma clara motivação: a ruptura com sua condição de 'servidores', a afirmação de sua condição de 'trabalhadores, ou seja, uma vontade de emancipação.” ${ }^{41}$ Uma carta foi lida e nela era questionado o discurso oficial do Estado frente à concretização das práticas:

As contradições evidentes entre nossas condições precárias de vida e trabalho e a propaganda oficial da Coordenadoria e da Secretaria da Saúde, que há dois anos e meio fala sobre as maravilhas da 'nova' orientação da política de Saúde, mostra-se de forma cristalina a cada dia. Fala-se da Equipe Multiprofissional, espaço democrático de relações hierarquizadas. Mas o que temos na prática? $O$ médico trabalhando em regime diferenciado: jornada de trabalho menor e salário maior. Fala-se de atenção a ser desenvolvida na comunidade, nas escolas e em outros grupos organizados, mas na avaliação mensal o nosso trabalho é aferido por um boletim de produção que só valoriza as atividades tradicionais de consultas e grupos psicoterápicos. Fala-se de integração e regionalização dos serviços, mas somos colocados lado a lado com colegas que possuem regimes diferenciados de jornada de trabalho e salário."

Além disso, repudiavam a Coordenadoria de Saúde Mental naquilo que consideraram “forma antidemocrática” na condução da organização do evento:

\footnotetext{
40 Alguns dos encontros: I Encontro dos Coordenadores de Saúde Mental da Região Sudeste, I Encontro Estadual de Saúde Mental do Rio de Janeiro, I Conferencia Estadual de Saúde Mental do Rio de Janeiro, II Encontro de Coordenadores de Saúde Mental da Região Sudeste.

${ }^{41}$ LANCETTI, Antonio et all. Saúde Mental e Cidadania. São Paulo, Ed. Mandacaru, 1987, p.85.
} 
"Denunciamos o congresso pelo congresso. Um congresso de trabalhadores só pode ser obra de nós mesmos. Por tudo isto, não somos e não seremos mais massa de manobra de Secretários, Coordenadores e Tecnocratas, que não medem esforços em sua autopromoção, ao mesmo tempo em que negam nossas justas reivindicações e nada fazem na direção dos interesses dos trabalhadores de saúde mental."

Desse modo, colocam em prática a idéia de que um congresso legítimo de trabalhadores deve ser feito por eles próprios. Foram criadas, nesse sentido, comissões responsáveis pela organização de um II Congresso. Este foi realizado com a participação de cerca de duas mil pessoas, tendo sido apresentados muitos trabalhos produzidos pelos profissionais, inclusive aqueles que não possuíam formação universitária.

Se por um lado, o Congresso possibilitou a discussão de pontos extremamente relevantes que dizem respeito à exclusão do 'doente mental' dos direitos civis, sociais e políticas; a relação entre Lei e Direito e o lugar ocupado pelos trabalhadores de Saúde Mental na produção e reprodução dos mecanismos de exclusão ${ }^{42}$; por outro, segundo Amarante, explicitaram-se as fortes divergências entre militantes do MTSM que estavam, de um lado, comprometidos com a administração estadual, e de outro, representando uma tendência emergente denominada Plenário de Trabalhadores em Saúde Mental, que buscava marcar uma distinção em relação às lideranças comprometidas com o poder público. ${ }^{43}$

A trajetória sanitarista da reforma psiquiátrica brasileira, assim denominada por Amarante, termina com a realização da I Conferência Nacional de Saúde Mental em 1987, desdobramento da $8^{a}$ Conferência Nacional de Saúde, realizada no ano anterior.

É importante ressaltar que com a realização desta $8^{\mathrm{a}}$ Conferência, a reformulação do Sistema de Saúde alcançou sua expressão mais acabada, cujas propostas trouxeram impacto na política de saúde do país. Nela foram demonstradas as vantagens da descentralização e da redistribuição do poder, representando o postulado essencial da democratização dos serviços, e foi possível a participação de entidades e representantes da sociedade civil pela primeira vez num evento dessa dimensão.

Tanto a organização quanto a realização da Conferência de Saúde Mental foram marcadas por uma série de conflitos entre membros do MTSM e dirigentes da DINSAM e da

\footnotetext{
${ }^{42}$ O lugar ocupado pelo trabalhador em saúde mental na produção e reprodução dos mecanismos de exclusão faz parte das reflexões do MTSM, já que se, por um lado, esse trabalhador "está convocado para administrar a situação de opróbrio dos usuários, a ortopedizar suas vidas e a acionar e justificar as instituições que os confinam total ou parcialmente; por outro lado, também o TSM é muitas vezes insistente na luta pelas vidas e destinos singulares. Nesse sentido, a luta pela emancipação do doente mental está diretamente associada à luta pela emancipação do TSM.” LANCETTI, Antonio et.all. op. cit., p. 92

43 Apesar de este período ter sido marcado, principalmente, por uma tendência institucionalizante, várias iniciativas contra-institucionais vinham se constituindo, o que permitiu a aglutinação de trabalhadores e alguns outros segmentos em torno do Plenário de Trabalhadores em Saúde Mental. O Movimento Popular de Saúde da Zona Leste, por exemplo, já vinha discutindo questões relacionadas à atenção psiquiátrica desde 1985.
} 
Associação Brasileira de Psiquiatria. A realização da Conferência vinha sendo postergada por parte da DINSAM, que nesse momento estava sendo dirigida por setores universitários declaradamente contrários ao projeto do Movimento. Apesar de incluir em seu discurso aquele produzido pelo MTSM, passa a afastar seus membros da condução política das unidades hospitalares. ${ }^{44}$

A partir do confronto que passa a existir nesse âmbito, membros do MTSM que ocupavam postos de direção municipais e estaduais tomam iniciativas em organizar conferências em seus níveis de influência para forçar a realização da conferência nacional. Muitas inovações foram introduzidas, espelhando-se na experiência obtida na $8^{a}$ Conferência, dentre elas, a distribuição das vagas de delegados priorizando também os representantes da sociedade civil e não somente aqueles das instituições e órgãos públicos. "Dessa forma, passam a merecer destaque singular as organizações de usuários, de psiquiatrizados, de familiares que, embora existissem desde algum tempo, encontravam muito pouco espaço para expressar suas opiniões e projetos nas instâncias oficiais de participação.” 45

Durante a I Conferência o MTSM realizou reuniões paralelas. Nelas discutiu-se a necessidade de criação de um "fórum independente”, no qual se pudesse exercer o ato crítico à política oficial, bem como refletir sobre práticas e organização do próprio movimento (rever estratégias, repensar princípios e estabelecer novas alianças). Como resultado das discussões foi constituída uma comissão nacional com o objetivo de organizar o II Congresso Nacional de Trabalhadores em Saúde Mental, na cidade de Bauru, em 1987. Este é para Amarante o final da trajetória sanitarista e início da 'trajetória de desinstitucionalização'.

O Congresso de Bauru representou, ao nosso ver, não apenas o início de uma das trajetórias da reforma psiquiátrica brasileira, mas também um momento de superação do próprio MTSM, a partir da ampliação de seus princípios e da participação de outros segmentos da sociedade civil, principalmente usuários dos serviços de saúde mental, ex-pacientes psiquiátricos e seus familiares, representantes de diferentes associações que passam a ser criadas principalmente no período que sucede à I Conferência Nacional de Saúde Mental. ${ }^{46}$

\section{3 - Movimento de Luta Antimanicomial: “Por uma sociedade sem manicômios”}

\footnotetext{
${ }^{44}$ No âmbito da reforma sanitária, o mesmo vinha acontecendo. No período que se sucede à implantação da Comissão de Reforma Sanitária, como desdobramento da $8^{a}$ Conferência Nacional de Saúde, muitos dos representantes do Movimento Sanitário foram progressivamente sendo demitidos de seus cargos.

45 AMARANTE, P. Op. cit., 1995, p. 98.

${ }^{46}$ Dentre estas podemos destacar: Sosintra (Sociedade de Serviços Gerais para Integração do Trabalho), a primeira a ser fundada em 1979; Associação Loucos pela Vida, formada por usuários, familiares e técnicos do Hospital do Juqueri, SP; Associação SOS Saúde Mental, formada de usuários, familiares, técnicos de saúde mental, representantes do movimento popular do município de São Paulo; Associação Franco Basaglia, composta por
} 
A convocação do II Congresso Nacional dos Trabalhadores em Saúde Mental, no ano de 1987 em Bauru, desencadeou um novo momento da história da reforma psiquiátrica do país. Da organização dos trabalhadores em saúde mental, juntamente com outras frentes, nasce o Movimento de Luta Antimanicomial (MLA) no Brasil, que vai ampliar os princípios e as formas de participação buscando uma articulação com movimentos democráticos populares. As associações de usuários e seus familiares passam a ter um papel de destaque nesse sentido.

"Na sua trajetória este movimento tem avançado da posição de um movimento de características de trabalhadores em Saúde Mental para um movimento social mais amplo, saindo de um caráter teórico e técnico, para uma intervenção política da sociedade." ${ }^{47}$

A ampliação se dá à medida que se produz uma crítica mais contundente aos manicômios, buscando excluí-lo como possibilidade de assistência ao doente mental e rejeitando a ambigüidade referente à humanização dos hospitais psiquiátricos existentes, posição esta que algumas vezes circulava no MTSM. O hospício passa a ser considerado emblema das relações de violência, segregação, massificação, difundidas em nossa sociedade. Do mesmo modo, o lema "Por uma Sociedade sem Manicômios" torna-se bandeira de luta do movimento emergente.

"O manicômio é expressão de uma estrutura presente nos diversos mecanismos de opressão deste tipo de sociedade. A opressão nas fábricas, nas instituições de menores, nos cárceres, a discriminação contra os negros, homossexuais, índios, mulheres. Lutar pelos direitos de cidadania dos doentes mentais significa incorporar-se à luta de todos os trabalhadores por seus direitos mínimos, à saúde, justiça e melhores condições de vida." 48

Em relação às resoluções do Congresso de Bauru, merece serem destacadas: a criação do Dia Nacional de Luta Antimanicomial, comemorado todos os anos no dia 18 de maio e a proposição de um projeto de lei federal. O MLA passa a se organizar, a partir desse momento, principalmente, em torno dessas duas deliberações.

usuários, familiares e técnicos do Centro de Atenção Psicossocial Luís Cerqueira, São Paulo; Associação Franco Rotelli, usuários, familiares e técnicos do sistema de saúde mental do Município de Santos-SP.

47 MLA. Relatório do Encontro Nacional da Luta Antimanicomial, 1993

${ }^{48}$ Manifesto de Bauru, pronunciado no II Congresso de Trabalhadores em Saúde Mental, 1987. 
Em 1989, o Projeto de Lei 3657/89 foi apresentado ao Congresso Federal, pelo Deputado Paulo Delgado (PT), dispondo sobre a extinção progressiva dos manicômios e sua substituição por outros recursos assistenciais e, também, regulamentando a internação psiquiátrica involuntária.

Este Projeto representou um avanço na organização do movimento, da mesma forma que as manifestações realizadas na semana que inclui o dia 18 de maio. A atividades da semana tornaram-se importantes formas de expressão, a partir de atos públicos, atividades artísticas e acadêmicas que manifestam posições críticas à existência dos manicômios, decorrentes das relações de exploração das sociedades que os inclui.

Neste mesmo ano de 1989, há uma mudança no quadro político nacional, incluindo a posse de governos democráticos populares em diversas cidades do país ${ }^{49}$. Nestes, os princípios antimanicomiais integraram-se às plataformas políticas de planos de governo, já que questões dessa ordem vinham sendo debatidas em seus núcleos partidários.

Além disso, as propostas de governo passam a ser enriquecidas por iniciativas de âmbito internacional tomadas, de um lado, por parte das Organizações Panamericana e Mundial de Saúde - OPAS/OMS, que culminou na proclamação da "Declaração de Caracas"50 em 1990, e, de outro, pela Organização das Nações Unidas - ONU, que teve aprovado em sua Assembléia Geral "Os Princípios para Proteção dos Portadores de Transtornos Mentais e Melhoria da Assistência em Saúde Mental” em 1991.

Nessa conjuntura, mais uma vez surge a abertura do espaço político dentro da máquina estatal que vinha tendo um processo de fechamento crescente. Parte significativa da militância assume postos oficiais imbuídos da implantação de modelos antimanicomiais orientados pelo MLA.

Diversas experiências inovadoras no sentido da criação de um modelo realmente substitutivo ao modelo manicomial hospitalocêntrico foram instaladas. O próprio MLA reconhece esse avanço. "Afinal são inúmeros cidadãos, outrora condenados aos círculos viciosos dos hospícios" agora instalados num novo contexto "marcado pela dignidade, pelo respeito e pela cidadania." "Espalhados pelo Brasil quase uma centena de novos serviços de

${ }^{49}$ No Estado de São Paulo o Partido dos Trabalhadores passa a governar cidades importantes como a própria capital paulista, Santos, Campinas, Ribeirão Preto, Santo André, São Bernardo do Campo, Diadema, entre outras.

${ }^{50}$ A Conferência Regional para a Reestruturação da Atenção Psiquiátrica na América Latina no Contexto dos Sistemas Locais de Saúde, convocada pela OPAS/OMS no ano de 1990, proclamou a Declaração de Caracas, na qual conclamava os "Ministérios da Saúde e da Justiça, os Parlamentos, a Previdência Social e outros prestadores de serviços, as organizações profissionais, as associações de usuários, as Universidades e outros centros de formação, e os meios de comunicação a apoiar a Reestruturação da Atenção Psiquiátrica de forma a assegurar o sucesso de seu desenvolvimento em benefício das populações da Região". Nela, apontou-se a premência de ampla revisão da legislação específica e também a proposição de ações de saúde mental inseridas no contexto da saúde geral, considerando a revisão crítica do papel hegemônico e centralizador do hospital psiquiátrico. 
saúde mental, animados a partir dos conceitos básicos do nosso movimento, inventam novas possibilidades de relacionamento." 51

Nesse momento de conjuntura favorável, um novo ânimo se instala nos locais de trabalho e conseqüentemente no MLA. Com a implantação de serviços extra-hospitalares, aumenta-se, simultaneamente, o contingente de trabalhadores em saúde mental nas instituições de saúde e de usuários e seus familiares beneficiados nesse processo.

Ao mesmo tempo, ações voltadas para a intervenção política mais ampla passam a ter visibilidade. Além da apresentação de Projeto de Lei no nível federal, são apresentados outros similares às Assembléias Legislativas de vários Estados: Santa Catarina, Rio Grande do Norte, Paraná, São Paulo, Rio de Janeiro, Minas Gerais, Pernanbuco, Rio Grande do Sul, Ceará e Distrito Federal.

Nesse sentido, o MLA passa a atuar também em outras frentes juntamente com Parlamentares. Em São Paulo, por exemplo, um grupo de militantes constituiu uma Comissão Técnica de Apoio à investigação do uso do Complexo Hospitalar do Juqueri pela repressão política, realizada por uma comissão de parlamentares da Assembléia Legislativa. Nas vistorias realizadas, os prontuários dos presos políticos que passaram pelo Juqueri foram obtidos. Além disso, uma das entidades ligadas ao MLA (Associação SOS Saúde Mental) propôs à Câmara Municipal de São Paulo e à Assembléia Legislativa uma vistoria do dinheiro público utilizado em alguns dos hospícios, o que culminou no descredenciamento e fechamento de alguns deles.

Nesse mesmo período, a realização de Conferências de caráter oficial, municipais, estaduais, nacional de saúde e saúde mental, possibilitou a participação de parte significativa de trabalhadores simpáticos aos princípios antimanicomiais e de outros segmentos e movimentos sociais.

A grande mobilização resultante destes encontros culminou na realização da $2^{a}$ Conferência Nacional de Saúde Mental, em 1992, marco histórico no processo de Reforma Psiquiátrica brasileira. Esta Conferência definiu uma nova fase, "na qual já não bastam as denúncias e as críticas às políticas oficiais de saúde mental, mas onde tornam-se realidade palpável, com resultados práticos e impactos visíveis nas políticas sociais, as recentes experiências de construção de novas e distintas formas políticas, culturais, jurídicas, sociais de se lidar com as loucuras, os loucos e o sofrimento psíquico.”52

Além de referendar parte dos princípios antimanicomiais, ela foi organizada por representantes de diferentes setores sociais (usuários, técnicos, governos e prestadores de serviços), o que possibilitou a participação paritária de delegados de diferentes setores: 50\% de

\footnotetext{
${ }^{51}$ Relatório do I Encontro Nacional da Luta Antimanicomial realizado em Salvador, Bahia, no ano de 1993.

52 AMARANTE, P. Novos Tempos em Saúde Mental. Saúde em Debate. CEBES, 37, 92, p. 4.
} 
vagas para entidades civis e 50\% para representantes da administração pública, prestadores de serviços, instituições formadoras e trabalhadores em saúde mental. ${ }^{53}$

Neste processo, o MLA saiu fortalecido:

“Nesta $2^{a}$ Conferência Nacional de Saúde Mental o Movimento da Luta Antimanicomial tem muitos motivos para comemorações. Afinal, pouco mais de 5 anos nos separam do Congresso de Bauru (dezembro de 1987), marco fundador desta nova perspectiva ética, teórica e técnica de convivência da sociedade com seus loucos, que através deste movimento tem se efetivado.

Nestes 5 anos, com muita garra e criatividade, soubemos construir um amplo leque de relações político-culturais, conquistando muitos aliados, montando as novas práticas e serviços, publicando e divulgando as nossas idéias, conquistando as ruas a cada ano nos dias 18 de maio, apaixonando o campo da saúde mental através do Projeto de Lei do Deputado Paulo Delgado. Hoje, nesta Conferência, coroamos estes esforços, interferindo decisivamente através da vontade coletiva dos trabalhadores de saúde mental e seus aliados (população organizada, usuários, sindicatos, familiares ...) na definição de uma Política de Saúde Mental comprometida com a cidadania dos doentes mentais e com a superação dos manicômios. "54

Durante a $2^{a}$ Conferência foram realizadas paralelamente reuniões do MLA, entre elas a Reunião Latino Americana da Luta Antimanicomial. Fruto de tais discussões, foi considerado pertinente a construção de um Encontro Nacional do Movimento da Luta Antimanicomial. Reconheceu-se que apesar dos avanços nessa trajetória, as limitações existentes nessa organização não deveriam ser ocultadas. Foram levantadas interrogações sobre a natureza e ética das intervenções e sobre a convivência coletiva no Movimento.

O I Encontro Nacional foi realizado em 1993 e registrou que 25\% dos seus quase 500 participantes eram usuários e seus familiares. ${ }^{55}$

"Compomos hoje um coletivo, onde as várias vozes, dos diversos segmentos da sociedade ecoam em uníssono: 'Por uma Sociedade Sem Manicômios'. Usuários, técnicos e familiares, fizemos da luta contra a exclusão

53 Participaram da $2^{\text {a }}$ Conferencia 1500 pessoas. Dentre estas, 500 foram eleitas como delegadas, em 24 Conferências Estaduais, precedidas de 150 Conferências Regionais. A realização da Conferência envolveu aproximadamente 20.000 pessoas entre usuários, familiares, trabalhadores, gestores e prestadores de serviços.(Fonte: Ministério da Saúde)

${ }^{54}$ MLA. Convocatória para a Reunião Nacional da Luta Antimanicomial, Belo Horizonte, 1993.

55 O I Encontro Nacional de Luta Antimanicomial deliberou a realização nesse mesmo ano do III Encontro Nacional de Entidades de Usuários, Familiares e Ex-Pacientes Psiquiátricos, onde foi produzida a Carta de Direitos dos Usuários e Familiares de Serviços de Saúde Mental. Em 1995 foi realizado o II Encontro Nacional da Luta Antimanicomial em Belo Horizonte. Neste, cerca de $41 \%$ dos participantes eram usuários e seus familiares. 
uma tarefa comum ... O movimento antimanicomial saiu mais fortalecido, mais confiante na nossa capacidade de reinventarmos a vida, e entre outras coisas, contribuirmos com a reforma psiquiátrica brasileira." 56

\subsection{1 - Algumas considerações sobre o MLA}

Entendemos a organização do Movimento da Luta Antimanicomial, como uma das etapas do processo voltado para a reestruturação da atenção em saúde mental que vem se desenvolvendo no Brasil desde final da década de 70. Este tem exercido importante influência na criação de uma cultura contra-hegemônica no que diz respeito à negação das instituições totais, tendo como um dos principais alvos as instituições psiquiátricas. A questão da extinção dos manicômios tem circulado fora do âmbito exclusivamente "psi” e as questões trazidas pelo Movimento tem tomado um vulto em nosso país de caráter mais abrangente, inclusive ocupando espaços nos meios de comunicação. ${ }^{57}$

Podemos identificar três grandes objetivos neste Movimento:

- extinção progressiva dos manicômios e criação de uma rede substitutiva aos hospícios;

- criação de uma nova cultura que supere a visão de naturalidade das relações de desigualdades;

- criação de nova legislação psiquiátrica que regulamente os direitos do doente mental.

Tais objetivos incluem-se na luta contra a exploração das sociedades capitalistas e, conseqüentemente, contra a violência e exclusão social delas decorrentes. Os manicômios apresentam-se como alvo, por expressarem, num sentido amplo, os diversos mecanismos de opressão desta estrutura social; e num sentido estrito, a própria instituição psiquiátrica.

Segundo a fala de um dos líderes do Movimento, o "estereótipo" da violência institucional é o hospital psiquiátrico. Para ele, quando se constata o triste quadro da realidade brasileira, onde pelo menos $2 \%$ da população já foi internada neste tipo de estabelecimento,

${ }^{56}$ Relatório final do I Encontro Nacional da Luta Antimanicomial, 1993.

57 Compilamos algumas reportagens publicadas em jornais brasileiros: Folha de São Paulo - "Brasil gasta Cr\$ 2,5 tri com manicômios. São Paulo faz censo de inquilinos de hospícios. Doentes se reúnem em parque" (23/11/92), "Fim dos Manicômios: Doentes mentais ocupam 20\% dos leitos do país" (18/05/92); Jornal do Brasil - Brasil tem 35 milhões de doentes mentais"(02/12/92), "Extinção dos manicômios divide psicoterapeutas" (23/12/90); Jornal de Brasília - "Conferência propõe reformulação do atendimento a paciente psiquiátrico" (05/12/92), "Pacientes negam doença mental e reivindicam o direito à cidadania" (04/12/92); Correio da Bahia "Liberdade para os malucos. Psiquiatras fazem campanha exigindo o fechamento de todos os hospícios" (01/09/90); Jornal Brasil Agora - "Doente mental vira cidadão"(jul/ago/92); Jornal do Campus - "Lugar de louco não é no manicômio" (02/09/93), "Programa de Saúde Mental quer tirar pacientes dos manicômios" (09/11/89); DCI -"Saúde Mental. Seminário discute novas soluções" (13/07/89); Jornal da Tarde - Butantã ganha Hospital Dia de Saúde Mental" (17/04/92); Shopping News - "Manicômios: o longo caminho da 
pode-se pensar numa situação de aceitação do hospício frente à doença mental ante a falta de outras alternativas. "Mais um alicerce de sustentação do modelo asilar é construído, constituindo-se numa verdadeira cultura manicomial, tal a convivência quase quotidiana da população com esses mecanismos de violência". A população perde, no seu entender, a capacidade de refletir sobre os processos sociais geradores do sofrimento e a capacidade de indignar-se frente aos horrores cometidos pelos hospitais psiquiátricos. "Legitima-se a impunidade institucional em nome do saber médico: os eletrochoques, as insulinoterapias, o choque por cardiozol, as síndromes por excesso de medicação, as celas fortes, as camisas de força, os maus tratos, os castigos, a distância da família e dos amigos, a perda definitiva do emprego, a rotulação e a estigmatização; e se sobreviver, a morte civil." ${ }^{58}$

Esta impunidade pode ser vista como calcada nos alicerces ditos científicos da medicina mental contemporânea em que a loucura é dada como imutável e ganha status de doença mental.

"No mundo moderno das doenças mentais, o homem não se comunica mais com o louco. Dado o corte razão/não razão, há, por um lado, o homem racional que encarrega o médico de lidar com a loucura. E, por outro, há o louco cuja relação com o outro se faz por intermédio de uma racionalidade abstrata 'que é ordem, constrição física e moral, pressão anônima do grupo, exigência de conformidade'. Entre o homem de razão e o homem de loucura não há mais linguagem comum. Se há discurso da razão sobre a loucura, não há discurso da loucura sobre a razão." 59

É buscando novas perspectivas na convivência social com a loucura, através de iniciativas desinstitucionalizantes (assistenciais, teóricos, culturais e legislativas), que o Movimento Antimanicomial tem se construído. ${ }^{60} \mathrm{O}$ desafio colocado para os trabalhadores em saúde mental que se organizam é o de ruptura e recusa de serem agentes da exclusão, da violência, da discriminação institucionalizada.

A busca de tal ruptura tem se apresentado como um processo extremamente complexo, o qual independe apenas da organização do movimento ou do grande envolvimento dos trabalhadores. O MLA reconhece que as relações manicomias são reproduzidas também na criação de novas práticas, já que estas são produtos da própria estrutura social que está ainda por ser transformada.

As contradições inerentes aos processos nos quais estão inseridos os trabalhadores em saúde mental - seja em suas formas de organização, seja na criação de práticas

extinção" (07/04/91); Metrô News - "Novos caminhos para tratar a saúde mental" (22/03/93); O Estado de São Paulo - Projeto de extinção dos manicômios provoca polêmica entre psiquiatras" (07/04/91)

58 DAUD Jr., N. Hospício no Brasil: a legitimação da violência. Revista Desbordar, nº 5, 1992, p. 30-31.

59 FRAYZE-PEREIRA, J.A. O que é Loucura. São Paulo, Ed. Brasiliense, 1985, p.48.

${ }^{60}$ AMARANTE, P.D.C.; ANDRADE, P.H. As Experiências Antimanicomiais e a Desinstitucionalização. In: Conjuntura e Saúde. NUPES/ENSP/FIOCRUZ. Rio de Janeiro, agosto 1993. 
- emergem no âmbito macro social/institucional e estão relacionadas às forças envolvidas na manutenção, ou superação, do modelo econômico capitalista, sustentado num ideário liberal (individualista, normalizador, excludente), hegemônico em nossa sociedade, e são expressas em diversas relações - burguesia X proletariado, movimentos sociais X Estado, sociedade global X instituição de saúde, instituição $X$ trabalhadores, trabalhadores em saúde mental $X$ usuário/familiares, usuários X familiares.

Como apontamos anteriormente, o crescimento significativo do MLA significou uma forma de superação do MTSM - o que possibilitou a ampliação dos princípios e propostas e de uma nova conjunção de diferentes setores sociais. Porém, esse novo momento carrega consigo novas contradições.

Do mesmo modo que a criação de serviços substitutivos pode representar uma nova versão da estrutura manicomial e as relações entre trabalhadores/usuários no âmbito do movimento, atualizar as relações assimétricas e de dependência dos segundos em relação aos primeiros, os espaços institucionais abertos nessa trajetória podem significar um novo tipo de cooptação e dependência do movimento às estruturas estatais.

O MLA busca se colocar numa posição autocrítica e de vigilância ininterrupta por reconhecer que a relação com o Estado burguês é de oposição e luta. Apesar de ter-se aberto à possibilidade de participação nos conselhos municipais, estaduais e nacional de saúde e de comissões de reforma psiquiátrica e, também, na atuação junto ao poder Legislativo, a influência dos empresários do setor privado da saúde/saúde mental em relação ao Estado continua nítida. Na avaliação do Movimento, esta relação não poderia ser diferente, já que “o Estado Brasileiro tem se pautado historicamente pelo autoritarismo, paternalismo, populismo e clientelismo, que responde ao interesse das classes dominantes”. Avaliam ainda que tendo visto o avanço do MLA, a política ministerial "procura ser uma equação entre a perspectiva do Movimento e os interesses empresariais no setor; o que na prática tem favorecido a permanência do parque asilar no Brasil.”61

Questões relativas a sua autonomia e ocupação (ou não) de espaços institucionais na estrutura estatal têm suscitado divergências e continuam representando parte dos dilemas que vinham sendo colocados em outros momentos dessa trajetória.

Como já apontamos, o MLA não é um movimento monolítico. Embora seus princípios digam respeito à convivência com a diferença, o próprio movimento reconhece sua dificuldade nesse sentido, principalmente naquilo que se expressa a partir da relação entre trabalhadores, usuários e seus familiares. O próprio termo usuário é reconhecido como carregando características rotuladoras e devendo ser questionado por restringir a plenitude dos sujeitos à sua condição relacionada aos serviços que utiliza.

\footnotetext{
${ }^{61}$ Relatório do I Encontro Nacional da Luta Antimanicomial. Op. cit., 1993.
} 
Assim, “esse crescimento da participação de usuário não significa uma convivência sem conflitos. Reconhece-se a existência de movimentos que compõem o MLA e a importância de cada um, com sua autonomia e dinâmica própria, manter encontros separados. Sendo assim, os conflitos são inevitáveis. A relação entre trabalhadores em saúde mental e usuários/familiares, muitas vezes, reproduz aquela estabelecida nos serviços, sendo nítida a ascendência destes sobre o segundo. O movimento de familiares vem crescendo com o apoio dos trabalhadores. Diferentes atores, diferentes inserções e formas de compreender o processo saúde x doença."62

Da compreensão do processo saúde $\mathrm{X}$ doença e as práticas dela decorrente, surgem outras contradições que permeiam o movimento antimanicomial. O campo de trabalho referente às práticas substitutivas, como já mencionamos anteriormente, apresenta-se incerto. A psiquiatria atual, enquanto referencial teórico/técnico, mostra-se ambígua e insuficiente. É crítica quanto à estrutura institucional tradicional, mas não o é quanto às terapêuticas decorrentes do modelo clínico.

O MLA salienta que “o modelo terapêutico de instituição até hoje preconizado só produzia efeitos através das práticas clínicas. No entanto, hoje se reconhece a necessidade de se considerar a complexidade das relações sociais, políticas, econômicas e peculiaridades da condição humana como forma de construir múltiplas e criativas possibilidades de assistências em saúde mental.” Neste sentido o fazer clínico deve ser pensado como um ato político. ${ }^{63}$

Mas um dos desafios a se enfrentar, afirma o relatório do MLA, é romper com a relação de poder entre técnicos/usuários. "A relação aí estabelecida não dá margem à 'neutralidade'. A invenção da assistência passa, fundamentalmente, pela mudança nesta relação. As pessoas que vão trabalhar nos novos serviços têm que querer romper com a relação tuteladora e transformá-la."64

Questões relativas ao lugar do trabalhador em saúde mental - sejam nos movimentos políticos, seja no cotidiano do trabalho - e de suas ações - fundamentadas (ou não) teórica e tecnicamente, suscitam contradições que permeiam todo esse contexto.

Buscamos, ao trazer aspectos históricos referentes à organização dos trabalhadores em saúde mental em movimentos sociais, apontar algumas das contradições constitutivas das relações estabelecidas nos âmbitos do Estado e dos movimentos em saúde mental, que consideramos determinantes na implantação de uma rede substitutiva.

Aquilo que diz respeito a esse âmbito de implantação e às relações dos trabalhadores envolvidos nesse processo será analisado mais exaustivamente do decorrer desse trabalho, por ser este nosso objeto de estudo.

\footnotetext{
${ }^{62}$ Ibidem.

63 Ibidem.

64 Ibidem.
} 


\section{2 - MODELOS DE ATENÇÃO EM SAÚDE MENTAL: A EXPERIÊNCIA DO MUNICÍPIO DE SÃO PAULO}

Considerada a trajetória política dos trabalhadores em saúde mental que se organizaram em torno de movimentos ligados à reforma psiquiátrica, discutiremos alguns aspectos relativos a um dos objetivos que vem sendo colocado como prioritário nesse percurso: a construção de um modelo de atenção em saúde mental substitutivo aos hospícios.

A constituição de um pensamento crítico em relação ao modelo psiquiátrico tradicional foi subsidiado, principalmente, pelos pensadores ligados à Rede Internacional de Alternativas em Psiquiatria, mencionados no capítulo anterior. No que diz respeito à implantação de práticas de atenção em saúde mental, consideramos importante destacar algumas das correntes internacionais de reforma psiquiátrica que de alguma forma contribuíram para a experiência brasileira.

No Brasil essa experiência surgiu tardiamente se comparada a países europeus e Estados Unidos, onde processos de reforma psiquiátrica vinham se consolidando desde o final da Segunda Guerra Mundial.

O período pós-guerra, momento de profundas transformações na realidade econômica, social e política mundial, exigia amplas reestruturações. Os países europeus, afetados diretamente pela guerra, buscavam sua reconstrução. Os Estados Unidos emergiam como grande potência mundial no mundo capitalista e buscavam consolidar esse lugar. A necessidade de remodelação do sistema psiquiátrico se fazia presente, já que, em ambos os continentes, a cronicidade das doenças mentais apresentava-se em altos índices e tornava-se alvo de preocupação governamental.

Nesse processo, a Europa sai num estado de empobrecimento geral. O número de mortos e mutilados na guerra supera a casa de meia centena de milhões. Os hospitais psiquiátricos são comparados aos campos de concentração, o que causa comoção geral na 
sociedade. Na França, por exemplo, quarenta mil doentes mentais morreram nos asilos em decorrência das péssimas condições desses estabelecimentos. ${ }^{65}$

No que diz respeito às questões relacionadas à psiquiatria, a "guerra recoloca a questão da razão e da desrazão em múltiplas faces. Afinal, quem eram os insanos? - os que restavam ainda milagrosamente vivos, sobrevivendo à fome e maus tratos abandonados atrás de muros e grades? - O que dizer daqueles milhares de militares, desativados aos quais durante o conflito, tudo fôra permitido e possível ...? Afinal , o que fôra e o que deixara de ser patológico?”66 Enfim, são colocados frente a frente o modelo clássico de internação X propostas de intervenção na comunidade como formas de desinstitucionalização.

Na Inglaterra, década de 40, as experiências de T.H.Main e Maxwel Jones introduzem o termo "comunidade terapêutica" e inauguram uma nova relação entre hospital psiquiátrico e sociedade. O termo consagrado por Jones passa a "caracterizar um processo de reformas institucionais, predominantemente restritas ao hospital psiquiátrico e marcadas pela adoção de medidas administrativas democráticas, participativas e coletivas, objetivando a transformação da dinâmica institucional asilar." ${ }^{67}$

A reforma sanitária inglesa, influenciada pelo trabalho das comunidades terapêuticas, equipara os hospitais psiquiátricos aos demais hospitais da rede para fins de regionalização (doentes mentais podendo receber cuidados nos hospitais gerais mais próximos de suas casas), e institui a equipe multiprofissional como forma privilegiada de atuação. A lei instaurada em 1959 (Mental Health Act) busca restituir os direitos de cidadania do doente mental eliminando, as bases legais para a compulsoriedade das internações. ${ }^{68}$

Na França, 1940, surge o movimento da psicoterapia institucional que também posiciona-se contra o caráter segregante e totalitário do manicômio. Os psiquiatras Bonnafé, Bolvet, Tosquelles desenvolvem um trabalho em hospital psiquiátrico a partir de uma perspectiva ideológica marxista.

Tosquelles, ao refugiar-se na França em decorrência da Guerra, depara-se com uma situação degradante instalada nos hospícios. Seus primeiros anos de trabalho, no Hospital Saint Alban, são marcados por um caráter de oposição ao nazismo. Rapidamente o hospital transforma-se em local de encontro dos ativistas da resistência, favorecendo o agrupamento de militantes marxistas, surrealistas, freudianos, os quais forjam o que mais tarde vem a ser um grande movimento de transformação da prática psiquiátrica na França. ${ }^{69}$

Nos anos 50, a conotação política do processo inicial da psicoterapia institucional vai desaparecendo e abre espaço para a expansão crescente da psicanálise. A partir da explosão

\footnotetext{
65 BIRMAN, J.; COSTA, J.F. “Organização de instituições para uma psiquiatria comunitária”. In AMARANTE, P. Psiquiatria Social e Reforma Psiquiátrica. Rio de Janeiro. Editora FIOCRUZ, 1994.

${ }^{66}$ PITTA-HOISEL, A.M. Sobre uma Política de Saúde Mental. São Paulo, Dissertação (Mestrado). Departamento de Medicina Preventiva, Universidade de São Paulo, 1984, p.5.

${ }^{67}$ AMARANTE, P. Op cit., 1995, p.29.

${ }^{68}$ PITTA-HOISEL, A. P. Op cit., 1984.
} 
psicanalítica, após a guerra, instaura-se um movimento para a introdução deste referencial teórico-técnico nas instituições psiquiátricas.

Na década de 60, a psiquiatria de “setor”, que surge historicamente no pós-guerra, é incorporada à política oficial na França. A partir de medidas político-administrativas, territórios passam a ser divididos em setores geográficos compostos por 70 mil habitantes, em média. Nestes territórios são construídas estruturas psiquiátricas, onde incluem-se equipes profissionais (formadas por psiquiatras, psicólogos, enfermeiros, assistentes sociais), tais como: ambulatórios, hospitais dia e dispensários que se articulam com os hospitais psiquiátricos. ${ }^{70}$

Saindo da Europa e partindo para o continente americano, nos Estados Unidos, apesar da Segunda Guerra ter introduzido reflexos nas condições das instituições psiquiátricas, as mudanças assistenciais só vêm ganhar força a partir da década de 60, durante o governo do presidente Kennedy.

Em 1963, é instituída a primeira política nacional americana de cuidados comunitários para saúde mental, que busca, entre outros objetivos, uma reforma na assistência hospitalar visando a reinserção do paciente na comunidade. ${ }^{71}$ Essa Psiquiatria Comunitária ou Preventiva passa a representar um novo território para a psiquiatria ao definir seu objeto, a saúde mental, e seu campo de ação, a comunidade. A ação preferencial deve se dar no espaço social, abandonando-se desse modo a reforma do hospital psiquiátrico como ação prioritária. "Responsabilidade de todos, cidadãos e governo, instituições públicas e privadas, a estratégia de promoção da Saúde Mental se explicita, tornando-se a preocupação referida da Nova Psiquiatria. Esta mudança vai surgir no plano teórico, através de uma abordagem preventiva da enfermidade mental." 72 Instalava-se nesse modelo uma "crença" de que todas as doenças mentais podem ser detectadas precocemente e, assim, serem prevenidas.

A contribuição teórica nesse processo aproxima-se da produzida no campo da Saúde Pública, principalmente a partir do conceito de História Natural da Doença enunciado por Leweall e Clark ${ }^{73}$, que discrimina "três tempos na formação e desenvolvimento da enfermidade, até a sua resolução, e estabelecendo três formas diversas de intervenção, de acordo com o momento de sua constituição: prevenção primária, secundária e terciária.”74 ${ }^{74}$ modelo de História Natural é transposto para o campo da Saúde Mental, sendo Caplan ${ }^{75}$ seu principal formulador.

\footnotetext{
${ }^{69}$ FLEMING, M. Ideologias e práticas psiquiátricas. Porto, Afrontamento, 1976.

${ }^{70}$ Cf. PITTA -HOISEL, 1984, e AMARANTE,1995.

${ }^{71}$ PITTA-HOISEL, A. M. Op cit., 1984.

${ }^{72}$ BIRMAN, J.; COSTA, J.F. Op cit., 1994.

${ }^{73}$ LEAVELL, H.R.; CLARK, E. Preventive medicine for the doctor in his community. New York, Mcgraw-Hill, 1965.

${ }^{74}$ BIRMAN, J.; COSTA, J.F. Op cit., p.54.

${ }^{75}$ CAPLAN, G. Princípios da Psiquiatria Preventiva. Rio de Janeiro, Zahar, 1989.
} 
O projeto do presidente Kennedy é adotado pelas Organizações Panamericana de Saúde e Mundial de Saúde e, conseqüentemente, por vários países do terceiro mundo. Os EUA passam a exercer influência marcante e predominante nesses países.

No Brasil, os discursos propositivos na área de saúde mental e as práticas daí decorrentes, que se contrapunham de alguma forma ao modelo privatizante enunciado a partir do âmbito estatal, como já apontamos no capítulo anterior, tiveram como referência o modelo preventivista americano.

As reformas propostas, por um lado, pela Inglaterra e França e, por outro, pelos Estados Unidos, apesar de dizerem respeito a diferentes contextos e, aparentemente, não apresentarem sintonia (em relação aos objetivos e locais onde estes podem ser alcançados), têm em comum o fato de buscar a promoção de Saúde Mental como processo de adaptação social. ${ }^{76}$

Desse modo, privilegia-se a criação de serviços assistenciais na comunidade, deslocando-se a ênfase até então dada ao hospital psiquiátrico, esperando ter como consequiência o enfraquecimento da estrutura asilar e sua "possível” humanização, ou seja, propiciar "reformas” do modelo psiquiátrico tradicional.

Contrapondo-se a estas correntes, o movimento de antipsiquiatria na Inglaterra e a psiquiatria democrática italiana vêm questionar a estrutura asilar, buscando a desconstrução do aparato psiquiátrico legitimado por saberes, práticas e instituições.

Na corrente dos movimentos de contracultura surge, no início da década de 60, a antipsiquiatria, liderada pelos psiquiatras ingleses Ronald Laing, David Cooper, Aaron Esterson, entre outros. Para este grupo, os saberes e práticas psiquiátricas são inadequados no trato à loucura, que é entendida como um fato social e político, podendo representar inclusive uma experiência libertária.

O projeto anti-psiquiátrico apresenta-se como um desejo de negação da psiquiatria e também como "um movimento de crítica da ordem social estabelecida, não como a elaboração de uma nova doutrina ou de um saber instituído (facilmente recuperado pelo sistema), mas como um movimento de contestação radical das estruturas sociais e dos valores culturais, tais como a adaptação, a normalidade, a saúde mental... Esta constestação é posta em prática pelos próprios comunitários, que em ruptura com os modelos tradicionais de vida, criam novas formas de relações humanas entre os chamados 'normais' e 'anormais',,77

Sob esta perspectiva, a transformação das relações interpessoais, influenciada pela mudança de valores e idéias, é entendida como a base das mudanças radicais da sociedade, ao contrário da ênfase na transformação das relações econômicas dada pelas tendências de orientação marxista.

\footnotetext{
${ }^{76}$ BIRMAN, J.; COSTA, J.F. Op cit., 1994, p.44

${ }^{77}$ FLEMING, M. Op. cit., 1976, p.70.
} 
Laing e Cooper propõem, entre outras práticas, a criação de grupos comunitários voltados para experiências que possibilitem a libertação pessoal. “A generalização desta libertação à escala microsocial, de muitos grupos de pessoas - acto de contra violência e de denúncia do absurdo das instituições sociais burguesas - conduzirá então a transformação à escala macrosocial." 78

A antipsiquiatria tem o grande mérito de formular uma crítica radical ao saber médico psiquiátrico, revelando seu fundamento ideológico; subverter os limites da normalidade $\mathrm{X}$ anormalidade; denunciar valores culturais relacionados com a loucura e com as formas de organização social. Entretanto, ela não ultrapassou um nível superficial de análise política e permanece enfeudada à ideologia burguesa. De acordo com Fleming, “ao privilegiar o aspecto individual da revolta, promovendo o esquizofrênico ao estatuto de revolucionário, enaltecendo o carácter subversivo da loucura em si mesma, a anti-psiquiatria veicula ainda o individualismo e o gosto exótico, tão característico da pequena burguesia radical.” 79

A experiência italiana, numa outra perspectiva de ação, vai representar, segundo Barros, um confronto com o hospital psiquiátrico, o modelo da comunidade terapêutica inglesa e a política de setor francesa, apesar de conservar alguns de seus princípios (democratização das relações entre atores institucionais e a idéia de território). ${ }^{80}$

Para Franco Basaglia, principal expressão do movimento italiano, a psiquiatria inglesa foi a primeira a acentuar o aspecto social no funcionamento do manicômio, entretanto, as comunidades terapêuticas e do, mesmo modo, os setores representaram apenas uma reciclagem da velha gestão manicomial. “A psiquiatria inglesa, com o pragmatismo científico inglês, e a psiquiatria francesa, com a ideologia psicanalítica, cobriam as contradições que se haviam evidenciado.",81

Segundo Barros, “a gestão comunitária que procurava apenas humanizar o manicômio não colocava em discussão as relações de tutela e custódia e nem questionava o fundamento da periculosidade social contido no saber psiquiátrico.”82

Apesar da experiência inglesa ter sido grande referência para a psiquiatria italiana, ela foi sendo constantemente criticada por não ter trazido transformações de fato à estrutura manicomial. A experiência italiana consolidava-se no sentido de considerar como única saída possível para o enfrentamento da doença mental a eliminação de tais estruturas. ${ }^{83}$

\footnotetext{
${ }^{78}$ Ibidem, p. 69.

${ }^{79}$ Ibidem, p. 109.

${ }^{80}$ BARROS, D.D. Jardins de Abel: Desconstrução do Manicômio de Trieste. São Paulo. EDUSP: Lemos Editorial, 1994.

${ }^{81}$ BASAGLIA, F. Psiquiatria Alternativa: contra o pessimismo da razão, o otimismo da prática. São Paulo, Editora Brasil Debates, 1982, p.86.

${ }^{82}$ BARROS, D.D. Op. cit., p.59.

${ }^{83}$ As primeiras experiências de fechamento de manicômios na Itália se deram nas cidades de Gorízia e Trieste e foram lideradas por Franco Basaglia.
} 
Na década de 70 o movimento da psiquiatria democrática passa a coordenar a luta pela transformação do sistema psiquiátrico italiano. Era apontada a necessidade de se dar continuidade à luta contra a exclusão e contra o manicômio, porém, assinalando os perigos da reprodução de mecanismos de exclusão institucional mesmo nas instituições psiquiátricas extramanicomiais. ${ }^{84}$

Em 1978, foi aprovada pelo Parlamento Italiano a Lei $\mathrm{n}^{\circ} 180$ que "proibia novas internações em manicômios, determinava seu esvaziamento progressivo e definia a necessidade da criação de estruturas territoriais que respondessem à demanda, abolindo a ligação imediata e necessária entre doença mental e a noção de periculosidade social.» ${ }^{85}$

Enfim, a psiquiatria italiana buscou radicalizar o processo de desconstrução das instituições, saberes e práticas manicomiais. No Brasil, o pensamento italiano tem influenciado a organização dos movimentos de saúde mental, desde a década de 70. No entanto, apenas a partir do final da década de 80 passa a ter ressonância como formas de ação no âmbito do Estado, a partir das experiências implantadas com a posse dos governos de esquerda e de centro-esquerda em diversos municípios brasileiros.

\section{1 - Do preventivismo à desconstrução: a invenção paulista de novas práticas em saúde mental .}

Como apontamos anteriormente, a experiência americana exerceu no Brasil forte influência nas iniciativas governamentais relativa aos programas de saúde mental. Vale ressaltar que tais iniciativas não se constituíram, no entanto, como uma política de Saúde Mental elaborada, mas apenas como medidas restritas a atividades setoriais de rotina. $\mathrm{O}$ discurso que muitas vezes se mostrava avançado e progressista, esvaziava-se de sentido a medida que se encontrava afastado da realidade das práticas cotidianas institucionais. ${ }^{86}$

No início da década de 80, num quadro de crises dos setores sociais, aprofundadas pela política econômica recessiva adotada pelo Governo, podemos destacar o agravamento da situação financeira do Sistema Previdenciário referente à assistência médico-hospitalar. Neste sentido, em 1981, foi criado por iniciativa do governo federal, o Conselho Consultivo da Administração da Saúde Previdenciária (CONASP).

\footnotetext{
${ }^{84}$ BARROS, D.D. Op cit., 1994.

${ }^{85}$ Ibidem, p.21.

${ }^{86}$ PITTA-HOISEL, A.M. Op cit., 1984.

A falta de política clara e elaborada dizia respeito não somente à saúde mental, mas a toda a área de saúde pública.
} 
O CONASP tinha como objetivo não explícito retirar a "administração da assistência médica hospitalar previdenciária da influência do clientelismo político e do empresariado do setor". ${ }^{87}$ Para Pitta-Hoisel, o Plano de Reorientação da Assistência à Saúde no âmbito da Previdência Social, elaborado por esse Conselho, pode ser considerado o primeiro documento oficial e público que analisa crítica e seriamente os aspectos estruturais da assistência médica e, também, que possibilitou uma discussão mais ampla em distintos setores profissionais, empresariais e econômicos diretamente envolvidos, apesar de suas origens autoritárias e de não aproximar o preconizado com o que realmente foi implantado.

Como desdobramento desse Plano, foi também elaborado o Programa de Reorientação da Assistência Psiquiátrica Previdenciária (1982), que preconizava a implantação de um modelo de atenção psiquiátrica integral com ênfase no tratamento ambulatorial integrado ao sistema de saúde geral, destacando a importância dos Programas de Saúde Mental Comunitária, ligados principalmente aos serviços universitários, que foram desenvolvidos no Brasil. $^{88}$

Dentre as proposições importantes contidas no Plano de saúde geral do CONASP (Plano de Reorientação da assistência à Saúde no Ambito da Previdência Social - 1983) merece destaque o Programa das Ações Integradas de Saúde (PAIS), o qual preconizava a regionalização progressiva do sistema de saúde. O PAIS deveria, sob direção do Secretário de Estado da Saúde, ser coordenado por uma comissão paritária formada por representantes dos Ministérios da Saúde, da Assistência e Previdência Social e pela Secretaria Estadual de Saúde. ${ }^{89}$

Tal Plano foi implantado na capital do Estado de São Paulo em 1983 pelo governador André Franco Montoro, representante do maior partido de oposição na época (PMDB).

A perspectiva de vitória do partido de oposição nas primeiras eleições estaduais (1982) após a instalação da ditadura militar de 64, mobilizou um grupo de técnicos (em sua maioria provenientes das experiências dos Convênios de 73) a elaborar um programa de governo na área de saúde mental, a partir de discussões efetivadas em seminários, jornadas e grupos de trabalho. ${ }^{90}$

Tal grupo elaborou um diagnóstico da situação psiquiátrica no Estado de São Paulo, levando em consideração a prevalência de doença mental, a quantificação da população hospitalizada e recursos disponíveis da rede extra-hospitalar.

A situação apresentava-se da seguinte forma: 17,2\% da população adulta e 8,4\% da população de menores de 15 anos apresentava algum tipo de sintomatologia mental passível

\footnotetext{
${ }^{87}$ Ibidem, p.61

${ }^{88}$ MPAS. Programa de reorientação da assistência psiquiátrica. Brasília, 1983.

${ }^{89}$ PITTA-HOISEL, A.M. Op cit., 1984.

${ }^{90}$ Ibidem.
} 
de algum tipo de atenção (dados de pesquisa realizada pela Faculdade de Saúde Pública-USP); 121 hospitais psiquiátricos (112 particulares e 9 do Estado); 18 ambulatórios de saúde mental na Grande São Paulo; 19 centros de saúde e 18 postos de saúde municipais oferecendo alguma ação em saúde mental.

Em relação aos hospitais psiquiátricos, constatava-se que estavam distribuídos pelo Estado de acordo com o interesse dos investidores e não da necessidade da população. Assim, existiam áreas com alta concentração de leitos e outras com grande escassez. Os hospitais públicos eram subutilizados enquanto os privados tinham a taxa de ocupação máxima preenchida (40\% hospitais públicos X 150\% privados). A população hospitalar era constituída basicamente por pacientes crônicos ou cronificados, sendo altas as taxas de reinternação e permanência nos manicômios. ${ }^{91}$

A rede extra-hospitalar, quando comparada à política de internação, era praticamente insignificante. A grande São Paulo, por exemplo, necessitava ter um número cinco vezes maior de ambulatórios do que o existente. Estes estavam organizados de tal forma que os setores administrativos tinham mais prioridade do que aqueles voltados para o atendimento da população. Suas condições de conservação da estrutura física apresentavam-se precárias ou em locais impraticáveis para a proposta de atendimento. O dimensionamento de pessoal variava de acordo com a região onde estavam implantados, o que sempre implicava defasagem (maior número de técnicos em áreas centrais e maior número de pessoal auxiliar na periferia). Além disso, as diferentes categorias não se constituíam equipes multiprofissionais na maioria das unidades.

As ações de saúde mental nos centros de saúde e postos de saúde contavam com equipes ou profissionais isolados (na maioria das vezes apenas um psicólogo), e desenvolviam práticas desarticuladas, com pequeno grau de resolutividade e sem suporte das instâncias governamentais. $^{92}$

As Ações Integradas de Saúde - AIS (nome que se deu ao plano PAIS) representavam um avanço no sistema de saúde do Estado de São Paulo. O convênio assinado entre Ministério da Previdência Social, o Ministério da Saúde, e o Estado de São Paulo, contando com a adesão do Município de São Paulo, seguia os seguintes princípios: a responsabilidade em relação à saúde da população e ao controle do sistema de saúde é do Poder Público; consideração do quadro de doenças mais prevalentes na definição de programas e ações nos níveis regional e local; integralidade das ações de saúde buscando superar as dicotomias

\footnotetext{
${ }^{91}$ Ibidem.

${ }^{92}$ PITTA-HOISEL, A.M. Op cit., 1984.

Segundo esta autora, as ações em saúde mental nos centros de saúde apresentam uma cronologia irregular. Tiveram início no município de São Paulo no ano de 1967, desencadeadas em três centros por três psiquiatras. A partir de 1973, os convênios com faculdades de medicina e enfermagem possibilitaram o desenvolvimento de modelos de atenção e sistemas de formação de pessoal, baseados no modelo comunitário.
} 
entre preventivo/curativo, individual/coletivo, ambulatorial/hospitalar; valorização das atividades básicas de saúde etc. ${ }^{93}$

Com a instalação desse convênio, os níveis estadual e municipal passaram a receber repasses financeiros para serem utilizados no reaparelhamento e reformas dos equipamentos públicos e contratação de pessoal para ampliação de serviços na área ambulatorial. Tais repasses foram destinados, na área de saúde mental, para ampliação da rede ambulatorial e de ações de saúde mental nas UBS, além de serem instituídos programas de supervisão clínica aos profissionais dos serviços. ${ }^{94}$

Além das AIS, o governo estadual formalizou uma proposta com o aval do governo federal, e financiada pelo Banco Mundial, denominada Programa Metropolitano de Saúde (1984). Propunha-se a implantação de um sistema de atenção integral à saúde em algumas regiões da Grande São Paulo.

Merece destaque nesse contexto a publicação em outubro de 1983, da "proposta de trabalho para equipes multiprofissionais em unidades básicas e em ambulatórios”, pela Coordenadoria de Saúde Mental do Estado de São Paulo. Este documento trazia uma proposta técnica, endereçada aos profissionais de saúde preocupados em inserir um tipo de atenção à saúde mental nas práticas institucionais.

Propunha-se que ambulatórios e centros de saúde pudessem se constituir em “espaços terapêuticos adequados à contenção do sofrimento psíquico”. As ações desenvolvidas nas unidades básicas de saúde deveriam se caracterizar como de "atenção primária, integrando profilaxia e tratamento". Os ambulatórios seriam responsáveis pela assistência secundária voltada para "ações mais complexas e individualizadas em termos de freqüência, duração e especificidade do atendimento", ${ }^{95}$

Sobre a política de saúde mental do âmbito do governo municipal, pouco se pode destacar nesse período. No ano de 1981 foram nomeadas quinze psicólogas para integrarem as equipes multiprofissionais dos Postos de Atendimento Médico (similar aos centros de saúde estaduais) que respondiam pelos serviços de orientação educativa. Apesar do objetivo inicial do trabalho ser de orientação voltada para a assistência materno-infantil, este não foi colocado em prática. O atendimento psicológico específico tornou-se a ação principal, já que havia uma demanda nesse sentido.

A partir da instalação das AIS no município de São Paulo e da sintonia entre governo estadual e municipal ${ }^{96}$ houve uma articulação entre ações municipais e estaduais de saúde. Posteriormente, a partir da realização das eleições municipais, tendo sido eleito o prefeito Jânio Quadros, instalou-se um grande distanciamento entre a política estadual e municipal.

\footnotetext{
${ }^{93}$ MPAS. Op cit, 1983.

${ }^{94}$ PITTA-HOISEL, A.M. Op cit., 1984.

${ }^{95}$ Separata dos Arquivos da Coordenadoria da Saúde Mental do Estado de São Paulo, Vol. XLIII 1982/1983 n ${ }^{\text {a }}$ especial.
} 
Apesar dos esforços institucionais e de alguns avanços voltados para transformação da caótica e desumana estrutura da rede de saúde, a implantação do Programa de Saúde Mental não produziu os efeitos esperados na viabilização de uma rede extra-hospitalar eficiente e de impacto nos problemas de saúde mental da população.

Para Goldberg, os atendimentos nos ambulatórios voltados para os pacientes mais graves (psicóticos, por exemplo) processava-se de forma homogeneizadora, muitas vezes consolidando-se uma relação de cronificação. Apesar do atendimento extra-hospitalar dentro dos princípios de regionalização, poucas eram as mudanças que de fato se imprimiam na vida dos pacientes psiquiátricos. De outro lado, as unidades básicas permaneciam com sua tradição de não atender pacientes psicóticos, havendo, desse modo, uma demanda reprimida que não chegava aos serviços. ${ }^{97}$

Além disso, num determinado momento nesse processo de implantação, houve uma desvitalização de investimento na rede extra-hospitalar. Goldberg considera também que “a estrutura burocrática autoritária dos serviços públicos em nosso país atua segundo cálculos eminentemente quantitativos, imediatamente reversíveis em estatísticas que possam ser apropriáveis como 'realizações', no universo dos interesses das políticas oficiais de larga escala". 98

Acrescentaríamos outras questões envolvidas no pouco impacto das ações de saúde implantadas. Além dos recursos financeiros do Estado continuarem sendo destinados prioritariamente à contratação de leitos hospitalares, sob o ponto de vista das ações implementadas, as críticas que vinham sendo endereçadas aos modelos de saúde comunitária também se verificaram na experiência paulista. Ou seja, a herança eminentemente preventivista do modelo americano significou, ao nosso ver, um novo projeto de medicalização e psicologização da ordem social. As UBS e Ambulatórios de Saúde Mental, por exemplo, passaram a receber inúmeros encaminhamentos, feitos principalmente pelas escolas públicas de ensino elementar, de crianças com queixas relacionadas ao seu desempenho escolar. Problemas relacionados principalmente à estrutura do sistema educacional são traduzidos pela escola e unidades de saúde como dificuldade de aprendizagem, hiperatividade, falta de estimulação, deficiência mental, desestruturação familiar etc. etc.

O programa preventivo possibilitou um grande aumento da demanda extrahospitalar (ambulatórios e unidades básicas de saúde), entretanto, isso não se traduziu em transferência de egressos dos hospitais psiquiátricos para esses serviços. Ao contrário, as internações continuaram na mesma medida e criaram-se novas demandas (a escolar é um exemplo delas). A extensão de oferta dos serviços impulsionou uma busca às UBS e

\footnotetext{
${ }^{96}$ O prefeito de São Paulo na época era Mário Covas, também do PMDB.

${ }^{97}$ GOLDBERB, J. Clínica da Psicose: um projeto na rede pública. Rio de Janeiro, Ed. Te Corá, 1994.

${ }^{98}$ Ibidem, p. 109.
} 
ambulatórios e, desse modo, tais serviços, ao não suportarem a pressão de novas demandas, passaram a ter grandes filas de espera.

Além disso, a "filosofia" preventivista passa a fazer parte dos discursos das equipes e a se instalar nos serviços. Estes, principalmente a partir dos atendimentos em grupos, ofereciam ações voltadas para "educação em saúde”, buscando “conscientizar” a população do modo "saudável de viver". Tais ações não deixam de representar novos sistemas e técnicas de controle social, onde a repressão e violência se expressam mascaradas pelo "ideal da prevenção".

Dentre as ações do Governo estadual, merece destaque, nesse contexto, a instalação de um novo equipamento de saúde mental, no ano de 1987: o Centro de Atenção Psicossocial Professor Luiz da Rocha Cerqueira (CAPS). O CAPS, serviço que procura integrar ações ambulatoriais e oficinas de trabalho com a estrutura de hospital-dia, influenciou a criação de novos serviços e a transformação daqueles já existentes. Tal experiência representou uma ruptura em relação às práticas cristalizadas e pouco resolutivas (mesmo aquelas desenvolvidas nos serviços empenhados numa ação de desospitalização), apontando uma nova via de reflexão sobre a loucura e de atenção aos portadores de transtornos mentais. Este projeto inaugurou nos serviços públicos brasileiros uma postura de "recusa do modelo sintomatológico em benefício da criação de uma clínica psiquiátrica renovada, deslocando o processo do tratamento da figura da doença para a pessoa doente". 99

Apesar de suas características inovadoras, a inauguração de apenas um serviço numa realidade complexa como a do município de São Paulo não poderia trazer impacto à situação mais geral dos pacientes psiquiátricos. A política de internação, como já apontamos, em nada se alterou em todo esse processo.

Paralelamente às ações desenvolvidas no âmbito governamental, relembremos que os trabalhadores em saúde mental do Estado de São Paulo vinham tendo seus ânimos acirrados pelo descompasso existente entre política estadual neste setor e resultados realmente obtidos. Muitos desses trabalhadores, militantes dos movimentos de saúde, organizaram-se também nas estruturas partidárias do Partido dos Trabalhadores - PT.

Alguns encontros de trabalhadores militantes ou simpatizantes desse partido foram organizados, tendo entre os principais objetivos a análise da atuação do governo estadual. Denunciavam a inoperância dos serviços de saúde mental, apesar da existência de verbas provenientes do CONASP e Banco Mundial e a manutenção das atividades lucrativas conveniadas entre Estado e hospitais psiquiátricos privados, contrariando os princípios de desospitalização propostos pelo governo. ${ }^{100}$

Além disso, afirmavam que a extensão dos serviços de saúde para a população significou a contratação de grandes contingentes de técnicos de saúde mental, os quais se

\footnotetext{
$\overline{{ }^{99} \text { GOLDBERG, J. Op cit., 1994, p.21. }}$

${ }^{100}$ Documento produzido pelo PT: O Partido dos Trabalhadores e a crise da Saúde Mental”, 1985.
} 
deparavam cotidianamente com contradições insuperáveis de tal política de Saúde. ${ }^{101}$ Proposições para uma política de saúde mental municipal foram elaboradas, seguindo orientação dos princípios antimanicomiais.

A partir de 1989, o PT, ao sair como vencedor nas eleições em vários municípios paulistas, buscou colocar em prática uma política desinstitucionalizante, voltada para a desconstrução dos saberes e práticas manicomiais, propondo ações que pudessem dar um passo além das ações estritamente desospitalizantes. ${ }^{102} \mathrm{~A}$ influência do pensamento basagliano se fez nítida nos pressupostos dos diferentes planos colocados em ação nos municípios que incluíram os princípios antimanicomiais em suas propostas de atenção e, desse modo, um novo momento se instala na história da construção de práticas substitutivas em saúde mental no âmbito institucional.

\section{2 - Construindo uma rede substitutiva: a experiência paulistana (1989-1992)}

A experiência paulistana merece ser destacada, já que a partir dela buscaremos refletir sobre as formas de inserção dos trabalhadores em saúde mental na implantação de práticas substitutivas aos manicômios.

Ao longo deste trabalho, várias vezes mencionamos a expressão modelos de atenção em saúde. Teceremos algumas considerações nesse sentido antes de discorrermos mais especificamente sobre nosso tema, pois tal expressão pode dar margem a diferentes interpretações.

Segundo Campos $^{103}$, modelo de atenção é um conceito que estabelece intermediações entre o que é próprio do campo técnico e também do político. Em outros termos, poderia ser entendido como uma "tradução para um Projeto de Atenção à Saúde de princípios éticos, jurídicos, organizacionais, clínicos, sócio-culturais e da leitura de uma determinada conjuntura epidemiológica e de um certo desenho de aspirações e desejos sobre o viver saudável. ... Modelo, portanto, seria esta coisa tensa, que nem é só política e tampouco tecnologia. Um

\footnotetext{
${ }^{101}$ Ibidem; e Documento produzido pelo Grupo de Saúde Mental do PT: “Retrospectiva e perspectivas”, 1985.

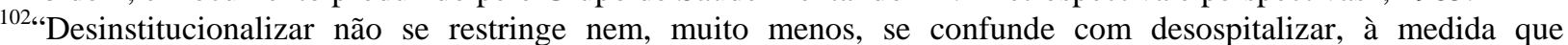
desospitalizar significa apenas identificar transformação com extinção de organizações hospitalares/manicomiais, enquanto desinstitucionalizar significa entender instituição no sentido dinâmico e necessariamente complexo das práticas e saberes que produzem determinadas formas de perceber, entender e relacionar-se com os fenômenos sociais e históricos.” AMARANTE, P. Op cit., 1995, p.53.

${ }^{103}$ CAMPOS, G.W.S. Modelos de Atenção em Saúde Pública: um modo mutante de fazer saúde. Saúde em Debate. CEBES, 1997, 32 (16-19).
} 
fenômeno cambiante que deve combinar categorias histórico sociais com outras cristalizadas em disciplinas supostamente construídas a partir de paradigmas epidemiológicos, clínicos e, no caso da saúde mental, do campo psi.”

A implantação de um sistema único de saúde no Brasil e, dentro dele, a superação de um modelo manicomial, ainda segundo Campos, vem ocorrendo de maneira paradoxal. A crise de financiamento do sistema de saúde tem provocado uma parcial e desordenada desativação de leitos hospitalares em todas as especialidades. Mas, decorrente desta situação, existe um esforço ordenado voltado para a criação de alternativas assistenciais em várias frentes que, também em virtude da crise financeira, vem se dando em ritmo lento. Além das limitações financeiras são considerados dois outros fatores que dificultam o desenvolvimentos dos modelos alternativos de atenção.

Um deles diz respeito às disciplinas ordenadoras do campo da saúde mental. Estas oferecem o fundamento sobre o qual se constroem os novos serviços e desempenham, ao mesmo tempo, uma função castradora devido ao seu enfoque normatizador. As "técnicas psi vêm se transformando em camisas de força, que aprisionam os profissionais em um emaranhado de regras e procedimentos que nunca podem ser obedecidos nos complexos e tumultuados espaços dos sistemas públicos.”104

Outro obstáculo refere-se à transposição das diretrizes ordenadoras dos sistemas públicos de saúde, como as noções de hierarquização e regionalização dos serviços e práticas, para o campo da saúde mental. Essa transposição permite um planejamento mais racional dos sistemas públicos, mas pode representar também um elemento de burocratização dos serviços que compõem esse sistema. ${ }^{105}$

A experiência paulistana buscou equacionar aspectos que se apresentavam contraditórios na proposição de um modelo de atenção em saúde mental, dentre estes, integrar as ações de saúde mental à atenção integral à saúde geral.

O município de São Paulo foi governado entre os anos de 1989-1992 pela prefeita Luiza Erundina de Souza. A principal característica que se buscou imprimir nesse período foi a de participação democrática e popular de diferentes segmentos sociais.

No âmbito da saúde, o plano municipal, publicado em maio de 1989, considerava São Paulo como um município "marcado por profundas desigualdades econômicas, sociais e demográficas” determinante também dos desiguais padrões de morbidade e mortalidade. Nesse sentido, considerava-se essencial compreender "a saúde e a doença como resultado do processo social”. Teria saúde na "sociedade capitalista periférica” quem tivesse "boas condições de vida e de trabalho”, ou seja, aqueles com “acesso à alimentação, ao saneamento básico, à educação, ao

\footnotetext{
${ }^{104}$ CAMPOS, G.W.S. Op cit,1992, p.17.

${ }^{105}$ Ibidem
} 
lazer.” Constatava-se que a grande maioria da população estava alijada desses bens, tendo assim sua saúde comprometida. ${ }^{106}$

Além disso, os equipamentos de saúde existentes no município eram insuficientes para oferecer a “cobertura desejada à população.” Considerando a condição de saúde da população como resultante do conjunto das condições de vida e partindo do princípio de que a "saúde é direito de todos e dever do Estado", propunha-se que as ações e serviços públicos de saúde integrassem uma "rede regionalizada e hierarquizada", constituindo um sistema único, organizado seguindo as diretrizes de descentralização, participação popular, atendimento integral (priorizando atividades preventivas, mas sem prejuízos dos serviços assistenciais), com a garantia de eqüidade no acesso aos serviços ("se as condições de vida são desiguais, logicamente as necessidades também serão, e as propostas não podem ser as mesmas”). A questão da saúde da população só poderia ser abordada considerando-se um enfoque multisetorial. $^{107}$

O planejamento das ações de saúde deveriam se dar a partir das "necessidades da população identificadas no nível das Unidades e dos Distritos de Saúde. Considerava-se o distrito de saúde como estratégia fundamental, voltado para organização e planejamento de todas ações a serem desenvolvidas no território dentro dele delimitado. Desse modo, entendia-se ser possível a resolução de grande maioria dos problemas de saúde nesse território $(90 \%$ de resolutividade), utilizando, entre outros, o mecanismo de referência e contra-referência entre os serviços internos a sua área de abrangência. ${ }^{108}$

Seguindo-se as diretrizes gerais do modelo de atenção em saúde, e incluindo os princípios antimanicomiais, foi elaborado no âmbito municipal, um plano de ação visando à substituição do modelo manicomial. Sobre os princípios do movimento antimanicomial, estes se mostraram visíveis na proposta de implantação do novo modelo e foram explicitados nos documentos técnicos da Secretaria Municipal de Saúde.

Em Para Compreender a Atual Política Municipal de Saúde Mental, 1989, afirmava-se que o novo programa de saúde mental e os agentes institucionais da administração municipal firmavam "compromissos técnicos, programáticos e políticos na busca de uma reversão da política de Saúde Mental estabelecida” na cidade de São Paulo. ${ }^{109}$

Seguindo os princípios manicomiais, buscava-se "demonstrar os mecanismos discriminatórios e violentos sobre a loucura e o doente mental” e, desse modo, criar estratégias em prol da defesa e construção da cidadania destes excluídos. Deveriam fazer parte dessa estratégia o "combate à cultura manicomial de massa”, a "implantação de um modelo de saúde

\footnotetext{
${ }^{106}$ SMS. Plano Municipal de Saúde. Prefeitura do município de São Paulo, 1989.

${ }^{107}$ Ibidem.

${ }^{108}$ Ibidem.

${ }^{109}$ Para Compreender a Atual Política Municipal de Saúde Mental do Governo Democrático e Popular da Cidade de São Paulo. Documento elaborado pela Assessoria de Saúde Mental -SMS, 1989.
} 
mental alternativo" e o estabelecimento de "um confronto político com o hospital psiquiátrico (emblemático manicomial) e com o amparo jurídico que o legitima." ${ }^{\text {"110 }}$

O modelo proposto teve como eixo a implantação de ações de saúde mental na rede geral de saúde do município e buscava "não cair nas armadilhas institucionais que produzem novos espaços de segregação na rede alternativa extra-hospitalar."111 Objetiva-se, assim, "não reproduzir modernamente as condições e segregação imposta pelo modelo asilar ao portadores de sofrimento mental." Constituiu-se um modelo assistencial com base na diversificação dos espaços institucionais e na diversidade das necessidades dos usuários dos serviços.

"Esse modelo de atenção à saúde mental prevê uma rede de serviços articulados em níveis de complexidade, que respeita o indivíduo como ser integral e que considera, para a compreensão desse sofrimento, o território onde ele está inserido, sua moradia, seu bairro, seu transporte, suas opções de lazer, seu salário, seu trabalho, suas relações, sua família.... A construção desse novo modelo de saúde, conta com a participação popular no seu planejamento, execução $e$ fiscalização, prevendo a educação popular na compreensão da determinação social do processo saúde/doença". ${ }^{112}$

Construir uma rede substitutiva aos hospícios foi a tarefa colocada pelo governo municipal no âmbito assistencial. A rede, por um lado, resgatava parte dos princípios colocados para a construção de um sistema único de saúde (regionalização, integralidade das ações, ações de referência e contra-referência, participação popular).

Por outro, entendida como entrelaçamento de vários âmbitos (inter-institucionais e da comunidade entre outros) e, conseqüentemente, como forma de responsabilização desses diferentes níveis numa construção processual e coletiva, buscava romper com a possível burocratização e definição fechada das relações estabelecidas entre os diferentes níveis de complexidade dos equipamentos de saúde, inclusive rompendo com os princípios de hierarquização nas ações de saúde mental. A sustentação dessa rede se daria num sistema de referência e contra-transferência que pudesse ser continente aos vários momentos de expressão dos sintomas relacionados ao sofrimento mental.

Assim, buscou-se, de um lado, potencializar e redirecionar as ações nos equipamentos de saúde já existentes, como as Unidades Básicas de Saúde, os Prontos Socorros e

\footnotetext{
${ }^{110}$ A Atenção à Saúde Mental no Município de São Paulo (1989 - 1986). Documento elaborado pelo Fórum Paulistano Permanente de Saúde Mental.

${ }^{111}$ Normas técnicas e padronização de condutas nas emergências psiquiátricas municipais; Normatização das ações de saúde mental nas UBS e Hospitais Dia em saúde mental municipais. Documento produzido pela Secretaria Municipal de Saúde - Assessoria de Saúde Mental, 1992.

${ }^{112}$ Ibidem.
} 
Hospitais municipais. De outro, criar equipamentos de atenção específica, como os Hospitais Dia, e também ações em espaços públicos, ampliando a possibilidade de inclusão de alguns grupos populacionais alijados do convívio social e das relações de lazer, a partir da instalação de Centros de Convivência e Cooperativas nos parques e clubes municipais. ${ }^{113}$ O Modelo de Reestruturação da Saúde Mental na Prefeitura de São Paulo foi assim representado:

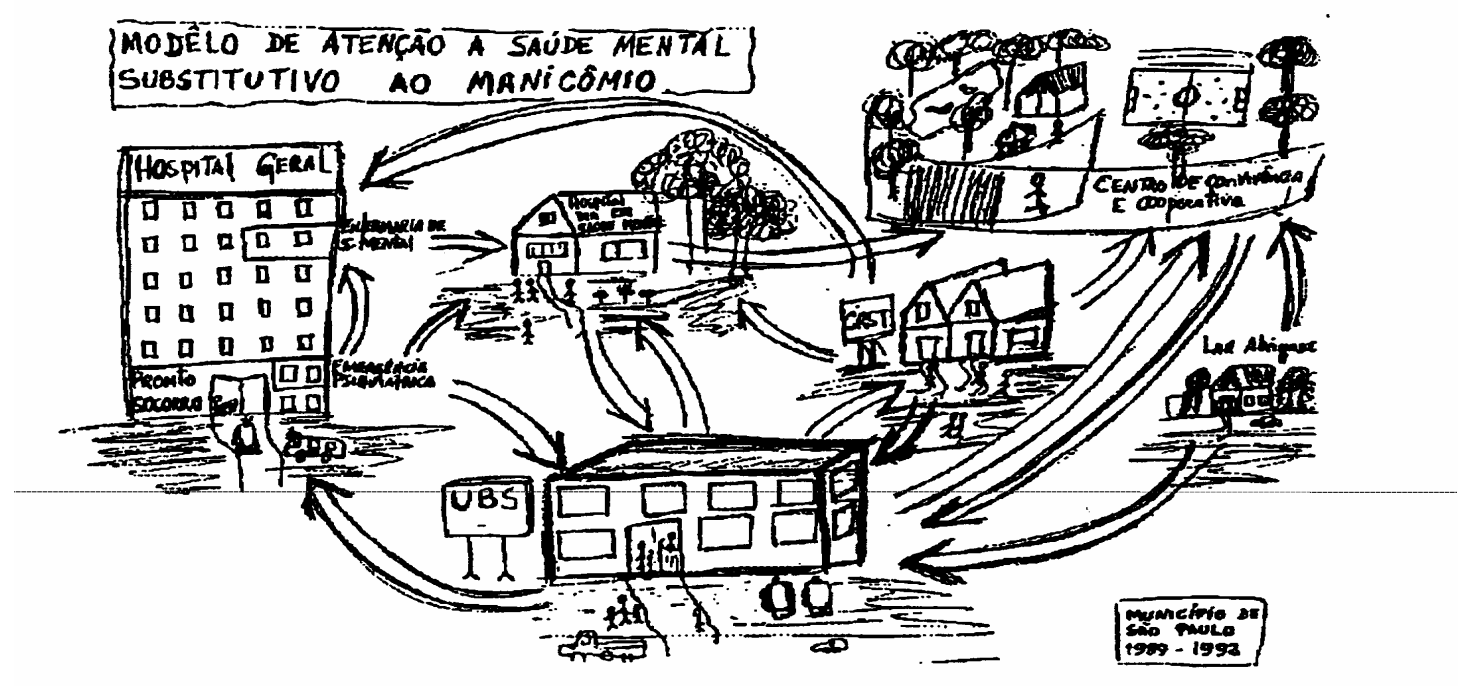

Fonte: Associação Movimento SOS Saúde Mental de Såo Paulo. Arquivos.

- Unidade Básica de Saúde - UBS

Ações de saúde mental foram implantadas nas UBSs a partir da contratação de profissionais para comporem uma equipe multiprofissional de saúde mental integrada à equipe geral da unidade.

“A Unidade Básica de Saúde conta com uma equipe de profissionais muito diversificada, sendo que todos podem e devem se envolver na atenção à saúde mental”, resguardando-se, no entanto, três níveis de responsabilidade: todos devem estar atentos a esse tipo de demanda nas ações de saúde desenvolvidas diariamente e podem se envolver nas atividades específicas; profissionais como os assistentes sociais, fonoaudiólogos, enfermeiros e educadores devem participar de uma parcela das atividades específicas; e psicólogos terapeutas ocupacionais e psiquiatras comporiam a "Equipe de Referência em Saúde Mental”. 114

As atribuições da Equipe de Referência, em ordem de prioridade, foram definidas da seguinte forma:

\footnotetext{
${ }^{113}$ Para Compreender a Atual Política Municipal de Saúde Mental do Governo Democrático e Popular da Cidade de São Paulo. Op cit. , 1989.

${ }^{114}$ Normatização das ações de saúde mental nas UBS e Hospitais Dia em saúde mental municipais. Assessoria de Saúde Mental - SMS, 1992
} 
1. atendimento ambulatorial aos usuários pertencentes aos grupos de risco em saúde mental (psicoses, alcoolismo, drogadição e tentativas de suicídio). Essa atenção deveria se dar considerando a ação da equipe multiprofissional;

2. realização de ações de saúde mental junto a instituições e grupos da comunidade da área de abrangência da unidade;

3. atendimento ambulatorial às demandas de saúde mental não pertencentes ao grupo de risco;

4. assessorar outros profissionais em questões relativas à saúde mental.

Além disso, sendo a UBS considerada uma das “portas de entrada” para o usuário na rede, a Equipe de Referência passou a ser responsável pela avaliação diária daqueles que procurassem espontaneamente ou fossem encaminhados à unidade, buscando triar os casos emergenciais daqueles que pudessem ser agendados ou reencaminhados.

A UBS deveria ter vagas reservadas para os encaminhamentos de HDs, emergências e enfermarias de saúde mental.

\section{— Hospital Dia em Saúde Mental - HD}

O HD foi previsto para cumprir papel fundamental na rede, tendo como função oferecer atenção intensiva ao paciente com sofrimento psíquico apresentando situação de crise, “sem exclui-lo do convívio familiar e social”. Desse modo, substituiria “a internação hospitalar em regime fechado por uma modalidade de tratamento ambulatorial intensiva e aberta.” Além disso, deveria "respaldar os pacientes egressos de hospitais psiquiátrico, visando dar seguimento à Reforma da Atenção em Saúde Mental.” 115

Sobre as ações a serem desenvolvidas, estas serão definidas "dependendo do espaço físico, composição da equipe e dos próprios usuários da unidade”. Estas deveriam contemplar atividades terapêuticas específicas (grupos de psicoterapia, terapia ocupacional, atendimentos individuais) e atividades básicas, onde predominam as atividades sócio-culturais (teatro, música, dança, jardinagem, horta, festas, grupo de auto-cuidados), garantindo um espaço de convivência." ${ }^{116}$ Dentre as atividades básicas seria possível também a realização de assembléias de pacientes e funcionários (discussão sobre funcionamento da unidade e programação de atividades), espaços de convivência (“acolhimento aos pacientes quando esses não estiverem participando das atividades formais”), revisão de medicação, grupo de reencontro (primeira atividade da semana e reinserir o paciente na rotina da unidade), grupo de fim de semana (“preparar o paciente para a convivência familiar e comunitária no final de semana”); atividades esportivas e de rotina (alimentação, higiene).

\footnotetext{
${ }^{115}$ Normatização das ações de saúde mental nas UBS e Hospitais Dia em saúde mental municipais. Documento produzido pela Secretaria Municipal de Saúde - Assessoria de Saúde Mental, 1992.
} 
O lugar ocupado pelo HD na rede, considerando o sistema de referência e contrareferência, seria o de dar retaguarda para UBS e Centro de Convivência e Cooperativas e ser referência para Emergência Psiquiátrica e Enfermaria de Saúde Mental do Hospital Geral. Desse modo, não funcionaria como "porta de entrada” do sistema.

- Hospital Geral: Saúde Mental Hospitalar, Emergência Psiquiátrica e Enfermaria de Saúde Mental

Os Serviços de Saúde Mental no Hospital Geral representavam a “integração da saúde mental com as outras áreas da saúde no contexto geral hospitalar do Modelo Integral de Saúde e no contexto específico das especialidades tradicionais” desenvolvidas nesse espaço.

A inclusão do serviço de emergência psiquiátrica no Pronto-Socorro do hospital geral foi entendida como "parte do processo de integração do usuário de serviços de saúde mental à sociedade”, buscando-se: uma "resposta alternativa e humanizada à segregação e à discriminação que ele (paciente psiquiátrico) sofre, uma possibilidade de aporte à família e o resgate de sua autonomia e participação no tratamento.”

Caberia a esse serviço o atendimento de indivíduos em situação de crise diagnosticada como: "psicose geral, psicose alcoólica, síndrome de abstinência, quadros de excitação psicomotora, quadros dissociativos histéricos, transtornos ansiosos, tentativas de suicídio, depressões, quadros de drogadição e distúrbios de comportamento nas deficiências mentais.” ${ }^{117}$ Do mesmo modo que a UBS, este serviço poderia funcionar como porta de entrada à rede de assistência. Os casos que necessitassem de internação temporária deveriam ser encaminhados para a Enfermaria de Saúde Mental do próprio hospital. A continuidade do tratamento se daria na UBS ou HD.

A inclusão desses serviços no hospital geral, associada a uma das diretrizes gerais da Secretaria Municipal de Saúde de combate às condições violentas de vida e à violência institucional na cidade, resultou numa proposta de reestruturação do próprio hospital geral, também entendido como instituição manicomial. Os princípios de desospitalização - redução das internações hospitalares aos casos estritamente necessários, priorizando ações preventivas e ambulatoriais -, de "humanização" das relações e de participação popular orientaram a implantação do Projeto Hospital Aberto em todas as unidades hospitalares municipais.

A estratégia principal de ação desse projeto foi garantir o direito a toda pessoa internada ou atendida nos prontos-socorros de ter a seu lado um acompanhante-participante. Entendia-se que essa abertura influía positivamente na recuperação do paciente por propiciar um apoio emocional a ele próprio e a sua família. Além disso, inaugurava uma nova forma de participação popular, pois, ao mesmo tempo em que o acompanhante poderia participar de ações

\footnotetext{
${ }^{116}$ Ibidem.
} 
junto ao paciente, tendo informações sobre o estado de saúde deste, poderia exercer o controle dos serviços e ocupar um lugar nessa instituição até então totalmente fechada à população de baixo poder aquisitivo, usuária dos serviços públicos.

Nessa perspectiva, o projeto Hospital Aberto apresentava-se como "forma de enfrentamento à violência institucional, enquanto prática cristalizada” exemplificada nas "relações de poder e de dominação dentro da Instituição, possibilitando a sua humanização, democratizando o direito à cidadania de pessoas internadas nos hospitais através do acompanhante-participante e de ações de saúde” que promovessem "a interdisciplinaridade e participação ativa de funcionário e clientela."118

A entrada do acompanhante-participante desencadeava no espaço institucional a emergência de conflitos entre população e agentes de saúde e, também, dentro da própria equipe, os quais precisariam ser superados coletivamente para a nova organização do hospital. Nesse sentido, esse projeto foi entendido como "instrumento capaz de gerar mudanças no próprio processo de trabalho em saúde."

A inserção de psicólogos nas equipes em todas as clínicas dos hospitais gerais, objetivando o atendimento integral dos internados e o desenvolvimento do Hospital Aberto, caracterizava as ações de Saúde Mental Hospitalar.

\section{- Centro de Convivência e Cooperativas - CECCO}

O implantação dos CECCOs foi considerada, no âmbito da construção da rede de saúde mental, como a experiência mais inovadora, pois buscava-se nessa proposta, "romper as regras de exclusão existentes nos parques e centros esportivos” para que estes pudessem se transformar em "centros irradiadores da convivência dos diferentes e locais de exercício da cidadania”. 120

Partia-se do pressuposto de que a "apropriação dos espaços públicos, dos bens culturais e da informação, por setores da população até então discriminados” poderia ser ponto de partida sobre um repensar sobre a loucura dentro dos setores sociais igualmente explorados/oprimidos porém não segregados.” Eram consideradas “discriminadas” as pessoas excluídas dos meios de produção, ou seja, os impossibilitados ou os sem chance de conseguirem uma ocupação (doentes mentais, portadores de deficiência física, idosos, meninos de rua, donas de casa, entre outros).

\footnotetext{
${ }^{117}$ Padronização de condutas e parâmetros técnicos nas emergêncas psiquiátricas. Assessoria de Saúde Mental SMS, 1992.

${ }^{118}$ COORDENADORES DO PROJETO HOSPITAL ABERTO. Hospital Aberto: Uma Síntese Possível. Cadernos CEFOR,, nº10, 1992.

${ }^{119}$ Ibidem.

${ }^{120}$ A Atenção à Saúde Mental no Município de São Paulo (1989 - 1992). Documento elaborado pelo Fórum Paulistano Permanente de Saúde Mental, 1996.
} 
A perspectiva do trabalho voltado para a questão da "loucura" justificava-se, principalmente, por que esta se remete a outras questões, tais como "a subjetividade, a cidadania, a disciplina, a violência, a expressão cultura, a alienação, as reações sociais de produção, a marginalização etc." ${ }^{21}$

Tendo-se em vista a implantação de um projeto com objetivo de amplo alcance social (não específico da área da saúde), abriram-se algumas frentes para sua concretização. De um lado, foram realizadas discussões junto a setores organizados da população e usuários dos parques e clubes e, de outro, o envolvimento de diferentes setores da estrutura administrativa da Prefeitura. Portarias Intersectariais foram assinadas, tendo, nesse sentido, a colaboração de diferentes Órgãos (Corpo Municipal de Voluntários, Guarda Civil Metropolitana) e Secretarias Municipais (Serviços e Obras, Esportes, Habitação, Educação, Abastecimento, Verde e Meio Ambiente) na concretização dos CECCOs.

As atividades nos Centros foram organizadas em formato de oficinas de arte (música, teatro, dança etc.), artesanato, lazer, passeios, práticas orientais que seriam monitoradas por diferentes profissionais da Secretaria de Saúde (psicólogos, terapeutas ocupacionais, fonoaudiólogos, auxiliares de enfermagem, educadores ) e técnicos de outras Secretarias.

Além da realização das oficinas, cujo objetivo era promover a interação e integração à sociedade das pessoas discriminadas, buscou-se a construção de Cooperativas, objetivando-se a "reinserção no mundo do trabalho através do incentivo à organização e produção em economia popular". Fez parte desse processo a definição de "parâmetros de produção, de divisão de lucro, de organização e processo de trabalho, em contínuas discussões acompanhadas pela equipe técnica do CECCO até o estabelecimento autônomo dos grupos em espaços outros."

- Lar Abrigado

Partiu-se da consideração de que a predominância de uma política hospitalizante no país criou "uma população psiquiatrizada crônica”, que "na verdade não tem mais um problema psiquiátrico e sim um problema social e vícios criados pela institucionalização. ${ }^{123}$

\footnotetext{
${ }^{121}$ Centros de Convivência e Cooperativas: Um ano e meio de história e prática. SMS

${ }^{122}$ LOPES, C. Centros de Convivência e Cooperativa: Alternativas de Liberdade. In Revista Desbordar, 5, 1992, 33-35.

Sobre este assunto vide também SANTOS, E.M. Centro de Convivência e Cooperativa: um caminho em busca de uma perspectiva alternativa em saúde mental. São Paulo, Dissertação (Mestrado). Faculdade de Educação, Universidade de São Paulo, 1994.

${ }^{123}$ Prefeitura do município de São Paulo. Esboço de Projeto nª 4: “Lares”, 1989.
} 
Esse paciente crônico não tem alternativas, já que sua família o interna de tempos em tempos por não possuir uma estrutura emocional e/ou social condizente para mantê-lo em casa ou, em outros casos, o esquece no hospital psiquiátrico.

Considerando tal realidade do paciente crônico, foi proposta a implantação de "lares abrigados”, ou seja, de espaços físicos que funcionassem como casas, onde os moradores poderiam ter a possibilidade de "reaprenderem as atividades quotidianas e sociais necessárias para viverem em comunidade, tais como: cuidados com a casa, fazer compras, cozinhar, relacionamento com outros moradores, trabalhar fora etc.” O objetivo final do Lar seria propiciar autonomia aos moradores, funcionando como um espaço intermediário entre saída do paciente crônico do hospital psiquiátrico e sua reinserção social. ${ }^{124}$

No final da gestão municipal (1992) haviam sido instaladas na cidade de São Paulo: 129 equipes multiprofissionais em UBS; 14 hospitais-dia; 18 CECCOs; 14 emergências psiquiátricas, 3 enfermarias de saúde mental, 70 unidades de saúde mental nos hospitais gerais. ${ }^{125} \mathrm{O}$ projeto Hospital Aberto foi incluído na estrutura de todos os quinze Hopitais Municipais. ${ }^{126}$ O projeto "Lar Abrigado” não chegou a ser concretizado.

Para a instalação dessa rede, além do investimento em recursos físicos e materiais foi necessária a contratação de um grande número de profissionais. Nesse mesmo período, ingressaram na rede, mais de mil novos trabalhadores em saúde mental. ${ }^{127}$

Vale ressaltar que a instalação de rede física e a contratação de profissionais não bastavam para a criação do novo modelo de atenção em saúde mental. Uma modalidade de trabalho centrada na atuação da equipe multiprofissional e a postura do trabalhador diante da nova tarefa foram consideradas essenciais nesse processo. Esses profissionais foram “ convidados a rever modelos, instrumentos e posturas, cuja formação acadêmica não previu para o exercício do trabalho, a fim de multidisciplinarmente e com a participação efetiva da comunidade promoverem leituras dos fenômenos sob um outro contrato ético que não o da psicoterapia” ${ }^{128}$, por exemplo.

A constituição de um trabalho em equipe multiprofissional poderia representar, nesse contexto, uma forma de contra-hegemonia ao lugar de destaque ocupado nas ações de saúde pelo saber médico-psiquiátrico tradicional. ${ }^{129} \mathrm{O}$ trabalho em equipe multiprofissional numa perspectiva de transdiciplinaridade era considerado como um dos pilares na construção de

\footnotetext{
${ }^{124}$ Ibidem.

${ }^{125}$ Fonte: Secretaria Municipal de Saúde, 1992

${ }^{126}$ COORDENADORES DO PRJETO HOSPITAL ABERTO. Op. cit., 1992.

${ }^{127}$ Fontes: Secretaria Municipal de Saúde, 1992.

${ }^{128}$ LOPES, C. Op cit, 1992.

${ }^{129} \mathrm{O}$ trabalho em equipe multiprofissional com tais objetivos não se restringia apenas às ações de saúde mental. A equipe multiprofissional apresentava-se como a principal forma de organzição de trabalho em praticamente todas as propostas apresentadas pela Secretaria Municipal de Saúde.
} 
novas práticas e uma das possibilidades de superação dos limites circunscritos da doença mental, tal como definido a partir do advento da medicina mental.

Entretanto, a efetiva constituição de equipes encontrava várias barreiras, dentre elas: a formação acadêmica das várias categorias profissionais, envolvidas na nova tarefa, não inclui sua preparação para o trabalho com a demanda de risco em Saúde Mental, com o enfoque e abrangência da Saúde Coletiva; a maioria dos profissionais contratados não possuía experiência no serviço público, sendo grande parte destes recém-formados; o trabalho em saúde mental envolve o "intercâmbio de subjetividades, o que requer complementarmente espaços diversificados de organização do trabalho, troca de experiências, equipes maduras” capazes de transformar os novos problemas da realidade assistencial em dinâmica interativa de transformação e aprendizado. ${ }^{130}$

Nesse sentido, colocava-se como prioritário o desenvolvimento de uma política de formação que respondesse às necessidades de implantação do novo modelo de atenção com sua característica antimanicomial.

Foram realizados vários projetos voltados para este fim (seminários, cursos, supervisões clínica e institucional etc.), culminando no último ano de governo na implantação de um grande projeto de formação, envolvendo parte significativa dos trabalhadores em saúde mental (cerca de 800 dos 1.200 contratados na rede até o início do projeto). ${ }^{131}$

Durante os quatro anos de governo foram constantes os pedidos, por parte dos trabalhadores à administração municipal, de ações que privilegiassem a formação, dentre estas a implantação de supervisões clínicas e institucionais.

Como já apontamos anteriormente, fazia parte da estratégia da política de saúde mental municipal, além da implantação de um modelo substitutivo, o confronto político com o hospital psiquiátrico e o combate à cultura manicomial.

Esta última deveria se dar a partir de um processo de educação popular que estimulasse a "reflexão crítica da população a respeito do seu sofrimento, da determinação social da loucura e das formas de exclusão". Foram propostas atividades em espaços públicos, parques, metrô etc., a partir da realização de exposições, museu itinerante, vivências públicas, cartazes, produção e exibição de filmes, entre outras. Os princípios da educação popular deveriam fazer parte também da rede de serviços implantada.

O confronto político com o hospital psiquiátrico se daria desde a instalação de uma rede que prescindisse de sua existência, passando pelo legislativo na instalação de leis antimanicomias até as ações de vigilância sobre o seu funcionamento.

\footnotetext{
${ }^{130}$ Projeto de Formação Permanente em Recursos Humanos na Área de Saúde Mental da Secretaria Municipal de Saúde, 1992.

${ }^{131}$ O Projeto de Formação Permanente em Recursos Humanos na Área de Saúde Mental será abordado com mais detalhes no próximo capítulo.
} 


\subsection{1 - Algumas considerações sobre o modelo paulistano}

A administração municipal entre os anos de 1989-1992 buscou fortalecer uma forma de governar a partir da inclusão de novos atores sociais ao processo de gestão, os quais eram identificados com a população excluída e segregada da cidade. Tinha-se como desafio administrar uma grande metrópole, objetivando "a democratização da administração municipal, a ruptura com os velhos padrões de fazer política, a inovação da dinâmica políticoadministrativa.",132

A inversão de prioridades no sentido de reorientar os investimentos públicos principalmente na área social e, nesse sentido, a ampliação dos serviços e equipamentos nas áreas de Saúde e Educação foram os principais objetivos estabelecidos desde o início da gestão.

O modelo implantado na Secretaria Municipal de Saúde transformou a estrutura administrativa a partir de uma política de descentralização - criação de administrações regionais e distritos de saúde - e do estímulo à participação popular em diferentes níveis de atuação Conselho Municipal de Saúde e Comissões Gestoras (regionais, distritais e locais).

As comissões gestoras de composição tripartite - representantes da administração, funcionários e população - foram instaladas praticamente em todos os níveis e serviços de saúde da rede.

No caso específico do modelo de atenção à saúde mental essa participação não apenas inaugurava uma nova relação entre comunidade e serviços de saúde mental como também impulsionava a própria organização do movimento antimanicomial no município de São Paulo.

A ação conjunta entre administração municipal e movimentos populares foi fundamental no avanço do modelo proposto. Conquistas no âmbito do legislativo, como por exemplo, a aprovação da Lei Orgânica de Saúde com princípios antimanicomiais, foram obtidas a partir do esforço conjunto entre estas partes. “A Emenda Popular de Saúde Mental de São Paulo, aprovada quase na íntegra graças à grande mobilização e apoio popular, foi referência para conquistas em outros municípios, ainda que parciais.”133

Em relação à implantação da rede de atenção em saúde substitutiva aos hospícios, foram visíveis seus impactos quando comparada aos serviços existentes até o ano de 1988. A criação de novos equipamentos como os HDs e CECCOs e implantação das equipes multiprofissionais em todos os serviços da rede propiciaram um aumento significativo de atendimentos anuais na rede extra-hospitalar municipal (cerca de 116.000, em 1992, contra 20.000, em 1988). Foram desativados, até o final de 1992, sete dos vinte e dois hospitais

\footnotetext{
132 JACOBI, Pedro. Op cit, 199 , p.161.

${ }^{133}$ Avanços na concretização da Política Municipal de Saúde Mental do Governo Democrático e Popular da Cidade de São Paulo. Documento da Secretaria Municipal de Saúde, 1990.
} 
psiquiátricos e 2.032 dos 4685 leitos existentes no início da gestão. Nesse sentido o número de internações diminuiu de, aproximadamente, 23.000 para 15.000 ao ano, o que significou uma queda percentual de $30,44 \%$. Esta queda se mostrou muito significativa quando comparada à ocorrida na mesma época no Estado de São Paulo e no Brasil, respectivamente, 9,40\% e $8,27 \%{ }^{134}$

Como já apontamos anteriormente, a política municipal de Saúde Mental não se reduziu à implantação de serviços ou contratação de profissionais. Considerando que a “inovação/invenção de alternativas institucionais visando à superação dos manicômios não é suficiente para quebrar a lógica de uma sociedade que sustenta e legitima os hospícios” ${ }^{\text {"135 }}$, várias ações desenvolvidas junto à sociedade e também medidas de impacto importantes foram tomadas. Entre estas últimas, podemos destacar a publicação da Portaria 198/1989, que proibia o uso de camisas-de-força e celas-forte nos serviços da Prefeitura.

Das ações desenvolvidas junto à sociedade, podemos destacar o desencadeamento de atos públicos, sociodramas, discussões em praças públicas das questões relacionadas ao sofrimento mental e a discussão permanente sobre a política antimanicomial com entidades e movimentos sociais.

Apesar dos indiscutíveis avanços obtidos de reestruturação administrativa e do impacto nos problemas de saúde da população, a implantação dessa proposta não transcorreu sem conflitos. A cultura manicomial não foi banida das instituições e nem poderia ser, já que tal superação só poderia se dar considerando transformações sociais mais amplas.

Apontamos em vários momentos, nesse trabalho, contradições presentes em diferentes tipos de relações consideradas determinantes na construção de práticas substitutivas em saúde mental: no âmbitos do Estado, dos movimentos sociais, da implantação de práticas etc.

Deste modo, elas também estão presentes no âmbito do governo municipal. A mudança de governo num município não implica total autonomia na definição de políticas econômicas e sociais, pois estas também dizem respeito tanto aos níveis federal e estadual, quanto a outras instâncias municipais, aos poderes legislativo e judiciário.

Além disso, elas manifestam-se também dentro do próprio governo, mesmo sendo este de característica democrático-popular. Devido a tais características a definição de diretrizes passa por uma discussão democrática que envolve além da equipe governamental outras forças de representação popular. Nesta discussão, nem sempre as posições e os interesses são consensuais.

A rede substitutiva paulistana, mesmo tendo se dado de forma incompleta, devido principalmente à reviravolta política (mudança de governo) em pleno processo de implantação,

\footnotetext{
${ }^{134}$ Fontes: Secretaria Municipal de Saúde, Fórum Paulistano Permanente de Saúde Mental e ONG Associação SOS Saúde Mental.

${ }^{135}$ A Atenção à Saúde Mental no Município de São Paulo (1989 - 1992). Documento elaborado pelo Fórum Paulistano Permanente de Saúde Mental, 1996.
} 
trouxe avanços no campo de atenção em saúde mental. Foi resultado de um longo processo de luta política pela democratização da sociedade brasileira, que vinha sendo travada por diferentes segmentos sociais, entre estes o Movimento Antimanicomial. A crítica construída ao aparato manicomial pôde finalmente penetrar no espaço institucional e, apesar de ainda não se configurar como uma concepção suficientemente elaborada, pode orientar grande parte das ações de trabalhadores e gerentes. Das críticas, elaboraram-se propostas e muitas delas traduziram-se em ações. Dentre as ações, muitas representaram a superação de antigas práticas do modelo psiquiátrico hegemônico. Parte delas foram apenas desconstruídas e outras não trouxeram inovação, simplesmente permaneceram. Deste contexto, novas problemáticas emergiram, seja no cotidiano do trabalho, seja na organização do movimento antimanicomial.

A concretização de um modelo de atenção substitutivo aos manicômios está intrinsecamente relacionada a questões de ordem econômica, política, social e intersubjetiva. Implantar novas práticas, considerando tal complexidade, implica poder equacionar diferentes âmbitos que vão do técnico ao político, do social ao individual.

Refletir sobre tais questões se faz necessário. Buscaremos a partir de agora iniciála, lançando nosso olhar sobre o lugar do trabalhador nesse complexa rede relações. 


\section{3 - A PESQUISA}

Nossa pesquisa foi realizada no segundo semestre de 1992, durante o desenvolvimento da primeira etapa do Projeto de Formação Permanente em Recursos Humanos na Área de Saúde Mental da Secretaria Municipal de Saúde de São Paulo. Nesse período, praticamente toda a rede substitutiva mencionada no capítulo anterior, já havia sido implementada.

Abordaremos, neste capítulo, questões relacionadas aos seguintes temas: o desenvolvimento do Projeto, cuja realização se deu em parceria com a Universidade de São Paulo, representada pelo Instituto de Psicologia; os fundamentos teóricos que orientaram a investigação e o nosso percurso de análise. 


\section{1 - O projeto de formação na área de saúde mental}

O desenvolvimento de uma política de formação voltada para os trabalhadores em saúde mental tem sido considerada - seja pelos trabalhadores e movimentos de saúde mental, seja nas definições dos princípios políticos voltados para ações de saúde - como fundamental na concretização de práticas substitutivas.

O Projeto de Formação Permanente em Recursos Humanos na Área de Saúde Mental iniciado em 1992, no município de São Paulo, buscou aliar os princípios de implementação da política de saúde mental municipal à reivindicação dos trabalhadores contratados para a rede. A exigência das equipes de saúde mental, responsáveis pelo novo trabalho, dizia respeito à implantação simultânea de um projeto de formação que privilegiasse a supervisão clínica e institucional.

Vale ressaltar que o pedido ao poder público para a contratação de supervisores tem sido freqüente por parte dos profissionais que atuam na área de saúde mental no serviço público.

Durante os três primeiros anos de governo, entre 1989 e 1991, houve apenas iniciativas distritais isoladas nesse sentido, devido a problemas de ordem burocrática, tal como a impossibilidade para a contratação de supervisores diretamente pelo município. No último ano, foi possível viabilizar um amplo projeto para a cidade, a partir do estabelecimento de convênio entre prefeitura e universidade.

Grupos de supervisão clínica-institucional constituíram o Projeto de Formação Permanente em Recursos Humanos na Área de Saúde Mental, resultado do convênio entre a Prefeitura do Município de São Paulo e a Universidade de São Paulo (PMSP/USP), através do termo aditivo entre Secretaria Municipal de Saúde e Instituto de Psicologia (SMS/PST-IPUSP). O Projeto foi desenvolvido durante o $2^{\circ}$ semestre de 1992 e $1^{\circ}$ semestre de 1993 (após a mudança de governo $)^{1}$, envolvendo cerca de 30 supervisores de diferentes instituições formadoras e 800 trabalhadores que se organizaram inicialmente em 36 grupos. Estes foram realizados em dez regiões de São Paulo, atingindo dessa forma todos os distritos da área metropolitana.

O Projeto privilegiava a formação de grupos de supervisão próximos ao local de trabalho dos profissionais, preferencialmente em espaços da própria administração pública. Constituíram os grupos profissionais de diferente formação - médicos, psicólogos, terapeutas

\footnotetext{
${ }^{1}$ Em 1993, Paulo Maluf assume a prefeitura de São Paulo. O Projeto continuou no primeiro semestre, apesar de não ser prioridade de seu governo, devido à parte da verba municipal estar destinada à esse trabalho, bem como ao estabelecimento de contrato com os supervisores por este período. Passado o primeiro semestre o Projeto foi desativado, do mesmo modo que, passado três anos de governo, foi desmontada a rede substitutiva a partir da implantação do Plano de Atendimento à Saúde - PAS.
} 
ocupacionais, assistentes sociais, fonoaudiólogos etc. - envolvidos na implantação do programa de saúde mental em equipamentos diversos - Hospitais Dia (HD), Centros de Convivência e Cooperativas (CECCO), Hospitais Gerais, Unidades Básicas de Saúde (UBS) etc. Propunha-se, ainda, que as discussões se dessem principalmente em torno de questões relacionadas ao atendimento das demandas de risco (psicose, neurose, drogadição e alcoolismo), na rede substitutiva.

Os supervisores, cuja contratação incluía pagamento pelas horas trabalhadas junto às equipes de saúde mental, eram representantes de diferentes instituições (IPUSP, Instituto Sedes Sapientiae, Hospital Dia A Casa, Instituto Pichon-Rivière) ou profissionais liberais (com experiência na rede pública de saúde). Eles foram indicados, em sua maioria, pelos próprios trabalhadores.

Ao IPUSP coube também, no Projeto, a função de desencadear um processo de investigação sistemática sobre os efeitos desse processo na constituição dos serviços.

\subsection{1 - Sobre o processo de investigação sistemática}

Integraram-se ao Projeto de Formação, alunos do curso de graduação em Psicologia do IPUSP, na qualidade de observadores de 14 grupos de supervisão.

Discussões sobre a técnica de observação foram com eles desenvolvidas. As observações foram orientadas pelo referencial teórico de Grupo Operativo, proposto por Pichon-Rivière, e tiveram acompanhamento sistemático (supervisões e discussões teóricas) por parte da coordenação do Projeto que representava a Universidade.

Aos alunos coube participar dos grupos de supervisão, com a tarefa de anotar o diálogo estabelecido entre trabalhadores e destes com supervisor, na medida do possível. Após o término de cada encontro, deveriam tecer comentários sobre o desenvolvimento deste (pontualidade, temática explicita e implícita que permearam as discussões) e suas impressões.

Foram entregues, ao final do semestre, protocolos de observação referentes a doze grupos de supervisão, constituídos em seis regiões da cidade de São Paulo. A freqüência dos alunos em cada grupo variou de dois a dez encontros, devido, principalmente, às mudanças de calendário e locais do encontro. Algumas vezes estes alunos não foram notificados sobre as mudanças.

Em síntese, foram analisadas, nesse trabalho, 70 sessões de supervisão, totalizando 133 horas de observação, conforme dados apresentados a seguir: 
Protocolos de observação analisados:

\begin{tabular}{|l|}
\hline Região \\
\hline ARS-1 (Sé) \\
\hline $\begin{array}{c}\text { ARS-2 Butantã// } \\
\text { Itaim/Lapa }\end{array}$ \\
\hline $\begin{array}{c}\text { ARS-2 Butantã/ } \\
\text { Itaim/Lapa }\end{array}$ \\
\hline $\begin{array}{c}\text { ARS-2 Butantã// } \\
\text { Itaim/Lapa }\end{array}$ \\
\hline $\begin{array}{c}\text { ARS-4 Tatuapé/ } \\
\text { Penha/Móoca }\end{array}$ \\
\hline $\begin{array}{c}\text { ARS-4 Tatuapé/ } \\
\text { Penha/Móoca }\end{array}$ \\
\hline $\begin{array}{l}\text { ARS-7 V.Maria } \\
\text { Brasilândia/FÓ }\end{array}$ \\
\hline $\begin{array}{l}\text { ARS-7 V.Maria } \\
\text { Brasilândia/FÓ }\end{array}$ \\
\hline $\begin{array}{l}\text { ARS-7 V.Maria } \\
\text { Brasilândia/FÓ }\end{array}$ \\
\hline $\begin{array}{l}\text { ARS-7 V.Maria } \\
\text { Brasilândia/FÓ }\end{array}$ \\
\hline ARS-9 S.Amaro \\
\hline ARS-!0 Campo Limpo \\
\hline TOTAL \\
\hline
\end{tabular}

\begin{tabular}{|c|}
\hline$n^{\circ}$ de encontros \\
\hline 2 \\
\hline 8 \\
\hline 2 \\
\hline 5 \\
\hline 2 \\
\hline 5 \\
\hline 6 \\
\hline 10 \\
\hline 8 \\
\hline 7 \\
\hline 10 \\
\hline 5 \\
\hline 70 \\
\hline
\end{tabular}

\begin{tabular}{|c|}
\hline $\begin{array}{c}\text { tempo médio por } \\
\text { encontro (horas }\end{array}$ \\
\hline 3 \\
\hline $1 \frac{1 / 2}{}$ \\
\hline 2 \\
\hline $1 \frac{1 / 2}{}$ \\
\hline $1 \frac{112}{}$ \\
\hline $1 \frac{1 / 2}{}$ \\
\hline 2 \\
\hline 2 \\
\hline $1 \frac{1}{2}$ \\
\hline 2 \\
\hline 2 \\
\hline 3 \\
\hline- \\
\hline
\end{tabular}

\begin{tabular}{|c|}
\hline $\begin{array}{c}\text { total de horas } \\
\text { observadas }\end{array}$ \\
\hline 6 \\
\hline 12 \\
\hline 4 \\
\hline 7.5 \\
\hline 3 \\
\hline 7.5 \\
\hline 12 \\
\hline 20 \\
\hline 12 \\
\hline 14 \\
\hline 20 \\
\hline 15 \\
\hline 133 \\
\hline
\end{tabular}

A previsão inicial do Projeto propunha organização de encontros de três horas, com periodicidade quinzenal, composto por vinte profissionais, em média. Entretanto, grande parte dos supervisores definiu, em comum acordo com seus grupos, outro tipo de organização. Alguns preferiram encontros semanais de uma hora e meia, outros, dividir os componentes do grupo que se encontrariam quinzenalmente, num período de uma hora e meia. Outros supervisores preferiram organizar encontros de duas horas.

Na divisão, em alguns casos, os profissionais agruparam-se por áreas específicas de atuação (por exemplo, apenas trabalhadores de UBS ou HD), contrariamente à proposta original de manter a heterogeneidade de equipamentos e profissionais. Além disso, também de forma discordante com a proposta original, alguns encontros se deram nos consultórios dos supervisores. 
Em relação à freqüência dos trabalhadores, apesar de não possuirmos o registro em números exatos, houve um crescente esvaziamento dos grupos observados até o final do Projeto. Tais questões serão discutidas no decorrer deste trabalho.

\subsection{2 - Considerações sobre a prática de supervisão nos serviços de saúde mental da rede pública}

A prática de supervisão, seja esta de caráter clínico e/ou institucional, tem se mostrado como uma das principais estratégias de formação para os trabalhadores dos serviços de saúde mental extra-hospitalares. Tal recurso tem sido privilegiado, principalmente, por reivindicação dos próprios profissionais concursados nos serviços públicos. ${ }^{2}$

Algumas de suas justificativas, ao enfatizarem a supervisão, fundamentam-se na necessidade de terem apoio de profissionais 'de fora' da instituição e 'mais experientes' na condução de reflexões que dizem respeito aos atendimentos e às técnicas utilizadas, à discussão teórica que possa sustentar as práticas e à própria constituição da equipe multiprofissional, bem como às relações que se dão no âmbito institucional.

Apesar de tais pedidos e justificativas dizerem respeito às diferentes categorias profissionais que compõem as equipes multiprofissionais dos serviços, consideramos que o psicólogo exerce grande influência na forma como são conduzidas e na ênfase dada à supervisão enquanto processo de formação. Isso porque ele tem desempenhado papel fundamental nas novas ações, as quais buscam superar o modelo médico. ${ }^{3}$ Além disso, representa a maior parcela entre os profissionais contratados para compor a equipe multiprofissional na rede ${ }^{4}$. Isso nos faz pensar que a implantação dessa prática tem se efetivado, principalmente, a partir do modelo desenvolvido nos cursos de Psicologia, por sua vez influenciados pelos cursos de formação em Psicanálise.

Sobre a formação do psicólogo, dados do Conselho Federal de Psicologia, 1988, revelam que no Brasil, a maioria deles atuam na área clínica, orientados por referencial de base analítica. Pesquisa apresentada ao CFP (1993), sobre o funcionamento das clínicas-escola -

\footnotetext{
${ }^{2}$ A supervisão tem-se mostrado prioritária para os trabalhadores desde o início de sua inserção nos serviços de saúde mental e dos primórdios da organização do Movimento de Trabalhadores em Saúde Mental. Na greve deflagrada na DINSAM em 1978 (vide cap.1), por exemplo, os estagiários grevistas destacavam, entre outras reivindicações, a criação de centros de estudos e supervisão profissional para os bolsistas; supervisão diária nos setores dos hospitais. In AMARANTE, op. cit., 1995.

${ }^{3}$ O psicólogo, tal como o psiquiatra, sempre atua no campo "psi”. São profissionais com formação específica na 'área mental' e, desse modo, tem ocupado lugar de destaque na equipe multiprofissional.

${ }^{4}$ No Estado de São Paulo, a partir de 1982, o governo ao buscar privilegiar o trabalho em saúde mental desenvolvido por uma equipe multiprofissional passa a contratar muitos desses profissionais. Estes, em muitos casos foram os únicos a se instalarem nas UBS. Passaram a trabalhar isoladamente nesses equipamentos como se fossem a própria equipe de saúde mental. Na prefeitura de São Paulo, como já apontamos, o início do trabalho em saúde mental se deu pela contratação de psicólogas para trabalharem nos PAMs.
} 
Serviços de Psicologia Aplicada - demonstra que a formação nestes serviços privilegia a área clínica, baseada no modelo médico e tendo como enfoque fundamental um referencial psicodinâmico. $^{5}$

Segundo Figueiredo apud Vilela (1996), no “início da década de 1970 o contingente de psicólogos formados já era grande e a clínica definitivamente eleita como a especialidade psicológica por excelência. O modelo de atendimento privado predomina em detrimento do trabalho nas instituições vinculadas ao Estado e a inspiração é predominantemente psicanalítica. A penetração da Psicanálise na Psicologia clínica - ponto chave de sua difusão no campo profissional - vai culminar no boom dos anos 70.” 6

Em São Paulo, segundo Coimbra, os psicanalistas apoiaram e respaldaram teoricamente os cursos de Psicologia e estiveram presentes massivamente nos cursos de graduação como professores. ${ }^{7}$

Historicamente, sob o ponto de vista da Psicanálise, a supervisão, ligada ao exercício da psicoterapia, passa a exercer progressivamente um papel importante na formação técnica do psicanalista desde a década de $20 .^{8}$ É entendida como a "psicanálise conduzida por um analista em formação e da qual presta contas periodicamente a um analista experimentado que o guia na compreensão e direção do tratamento e o ajuda a tomar consciência da sua contratransferência. Este modo de formação é nomeadamente destinado a permitir ao aluno aprender em que consiste a intervenção propriamente psicanalítica, relativamente a outros modos de ação psicoterápica (sugestões, conselhos, diretrizes, esclarecimentos, apoio etc.).”9

A mesma importância que a supervisão assume na formação do psicanalista passa a exercer também na do psicólogo, mesmo quando não segue a orientação analítica. Vilela, em pesquisa de 1996, ao entrevistar supervisores de estágio de diferentes cursos (Geologia, Oceanografia, Direito, Enfermagem, Nutrição, Serviço Social e Psicologia), constatou a existência de diferenças entre o tipo de estágio e supervisão em todos os cursos, porém uma delas se destacava em relação ao curso de Psicologia: a ênfase dada a essa prática mesmo após o término do curso de graduação.

Em todos os demais cursos, quando o aluno se forma, há um pressuposto da competência profissional, que caso julgue necessário, vai aprimorá-la em cursos e atividades afins, nunca recorrendo a um colega de forma profissional, diferentemente da Psicologia. ${ }^{10}$ Neste, inspirado em muitos aspectos nos cursos de formação oferecido pelas Sociedades de

\footnotetext{
${ }^{5}$ CAMPOS, L.F.L. "Supervisão em psicologia clínica: critérios, condutas e modelos de supervisão. São Paulo. Tese (Doutorado), Instituto de Psicologia da USP, 1994.

${ }^{6}$ VILELA, A.M.J. Formar-se Psicólogo: Como Ser Livre como um Pássaro. São Paulo. Tese (Doutorado), Instituto de Psicologia da USP, 1996.

${ }^{7}$ COIMBRA, C. Op. cit., 199

${ }^{8}$ MORATO, H.T.P. "Eu-Supervisão”: em cena uma ação buscando significado sentido. São Paulo. Tese (Doutorado), Instituto de Psicologia da USP, 1989.

${ }^{9}$ LAPLANCHE, J.; PONTALIS, J.B. Vocabulário da Psicanálise. São Paulo, Martins Fontes, 1988, p. 497.

${ }^{10}$ VILELA, A.M.J. Op. cit., 1996.
} 
Psicanálise, os futuros psicólogos são incentivados a buscarem sua análise pessoal e a continuarem com atividades de supervisão mesmo depois de formados, por ser considerada mecanismo fundamental para atuação profissional.

Voltando ao âmbito dos serviços públicos de saúde mental, a supervisão parece ocupar um lugar semelhante ao dos cursos de graduação em Psicologia e de formação em Psicanálise. Temos constatado a existência de uma necessidade contínua dos trabalhadores de que essa prática seja instalada como parte das ações implantadas.

A supervisão nesses serviços é colocada num lugar fundamental para a condução do trabalho. Em muitos casos, quando o poder público não a financia, o trabalhador realiza essa prática utilizando seus próprios recursos financeiros.

Ela parece se constituir numa entidade quase autônoma e independente no contexto dos serviços públicos, sendo conduzida por agentes considerados externos a esses serviços, portadores de um presumido saber. Desse modo, estaria preenchendo para os trabalhadores a lacuna criada de um lado pela formação profissional e, de outro, pelo caráter “novo” do trabalho que passam a desempenhar nas instituições de saúde mental.

Por ser essa uma prática tão requisitada pelos trabalhadores, local de investimento afetivo e financeiro, a supervisão pode ser considerada espaço privilegiado de expressão de suas angústias, dificuldades, realizações e insights ${ }^{11}$, relacionados às práticas e à convivência coletiva das equipes.

Além disso, pudemos verificar que a presença de um observador vinculado à pesquisa incluída no Projeto de Formação, representada pela Universidade, possibilitou a atualização de conflitos existentes entre trabalhadores, representantes da administração pública e, conseqüentemente, de indagações acerca da rede em saúde mental em implantação. ${ }^{12}$

Nesse sentido, os protocolos de observação analisados nessa pesquisa nos possibilitaram constatar vários âmbitos de conflito expressos na prática dos trabalhadores.

\footnotetext{
${ }^{11}$ Segundo Bauleo o insight poderia ser compreendido como percepções do tipo: “ 'cada um é como é’(Pichon Rivière) ou "cada membro deve aceitar e realizar não só sua individualidade como também a individualidade de todos seus iguais no grupo’ (Folkes).” BAULEO, A. Notas de Psicologia e Psiquiatria Social. São Paulo, Ed. Escuta, 1988.

${ }^{12}$ Lembremos que nesse momento os representantes do poder público em grande parte eram também militantes do movimento antimanicomial.
} 


\section{2 - O referencial teórico}

A observação dos grupos de supervisão bem como a análise de protocolos foram orientadas, principalmente, pelos pressupostos teóricos da Psicologia Social postulada por Enrique Pichon-Rivière.

É lançando mão dos conhecimentos da psicanálise, principalmente dos estudos de Melanie Klein e de conceitos da Psicologia Social de Kurt Lewin e George Mead, que Pichon-Rivière formula sua teoria. A perspectiva específica em Psicologia Social, por ele proposta, é "intersubjetiva, analisa o interjogo entre sujeitos, por um interacionismo que não desdenha a análise do acontecer intrasubjetivo, a eficácia dos processos inconscientes.” ${ }^{13}$ A dimensão intra-sujeito não pode ser compreendida se isolada da dinâmica vincular, na qual se dá a experiência do sujeito. "Da mesma forma, os processos intersubjetivos e, reconhecendo nestes os aspectos manifestos da situação, não podem ser compreendidos sem nos voltarmos à análise da estrutura do mundo interno. Tal postura é portadora de um conceito de estrutura, como um conjunto de relações em permanente transformação. Relações mutuamente determinadas entre sujeito-objeto, mundo externo e mundo interno.” ${ }^{14}$

"Esse mundo interno configura-se como um cenário no qual é possível reconhecer o fato dinâmico da internalização dos objetos e relações. Nesse cenário interior, tenta-se reconstruir a realidade exterior, porém os objetos e os vínculos aparecem com modalidades diferentes pela passagem fantasiada a partir do 'fora' para o âmbito intrasubjetivo, o 'dentro'. É um processo comparável ao da representação teatral, no qual não se trata de um repetição sempre idêntica do texto, mas onde cada ator recria, com uma modalidade particular, a obra e o personagem." 15

A articulação mundo externo $\mathrm{X}$ mundo interno, intersubjetividade $\mathrm{X}$ intrasubjetividade será tratada pela noção de vínculo, objeto da Psicologia Social aqui descrita. De maneira mais ampla, o vínculo pode ser entendido como a articulação entre a estrutura social e as fantasias inconscientes, a partir do interjogo entre o grupo externo e o grupo interno.

No âmbito das interações, o conceito de vínculo diz respeito à estrutura complexa que inclui um sujeito, um objeto, as reações do sujeito frente ao objeto, as reações do objeto frente ao sujeito, e a relação que se estabelece entre ambos. "O desenvolvimento de expectativas recíprocas, o intercâmbio de mensagens, permitem afirmar que interação implica

\footnotetext{
${ }^{13}$ FERNANDES, M.I.A De como emerge a questão do narcisismo e da alteridade no grupo operativo. São Paulo. Tese (Doutorado), Instituto de Psicologia da USP, 1989, p.40.

${ }^{14}$ Ibidem.

${ }^{15}$ PICHON-RIVIÈRE, E. O Processo Grupal. São Paulo, Ed. Martins Fontes, 1986, p. X.
} 
em processos de comunicação, ao mesmo tempo que fenômenos de aprendizagem, enquanto se dá uma modificação interna de cada um dos atores, modificação emergente do reconhecimento do outro, de sua incorporação, o que terá como efeito um ajuste em maior ou em menor grau do comportamento de ambos a essa realidade que significa a presença concreta do outro.” 16

Do contexto vincular emerge o sujeito, a partir de um constante interjogo entre necessidade $\mathrm{X}$ satisfação, que remete por sua vez a uma dialética intersubjetiva (indivíduo $\mathrm{X}$ contexto vincular social). ${ }^{17}$ Nesse sentido, a noção de sujeito é entendida a partir da idéia de que “o homem é um ser de necessidades que se satisfazem apenas socialmente em relações que o determinam”. ${ }^{18}$

A necessidade 'abre o jogo' entre sujeito e contexto. É experimentada enquanto "tensão interna e o envia ao mundo externo em busca de gratificação. Ela determina a primeira contradição experimentada pelo sujeito: necessidade X satisfação. Para superá-la, este 'sujeito da necessidade' opera sobre a realidade, material e simbolicamente e se transforma, transformando também o contexto externo". ${ }^{19}$

Qualquer traço da vida psíquica somente poderá se constituir a partir da experiência, de relações concretas. O psiquismo não se desenvolve desvinculado de uma relação experiencial e social, pois o "sujeito não é só um sujeito relacionado, é um sujeito produzido em uma práxis. Nele não há nada que não seja resultante da interação entre indivíduo, grupos e classes”. ${ }^{20}$

Nesse sentido, a Psicologia Social postulada por Pichon-Rivière propõe o desenvolvimento de três dimensões de investigação e, conseqüentemente, de três tipos de análise: a psicossocial, analisadora da parte do sujeito que se dirige aos diferentes membros que o rodeiam; a sociodinâmica, que analisa o grupo como estrutura; e a institucional, que consiste na investigação dos grandes grupos (sua estrutura, origem, composição, história, economia, política, ideologia etc.). Tais campos de investigação vão se integrando sucessivamente, não havendo uma separação clara entre eles. ${ }^{21}$

Os três âmbitos considerados apresentam-se como recortes metodológicos, nesse sentido cada manifestação do indivíduo, grupo, instituição ou comunidade leva consigo elementos das outras dimensões. Numa imagem figurada, o ato de interpretar poderia ser comparável ao efeito de um "zoom fotográfico, um ir e vir do micro ao macro, e vice-versa, que captaria diferentes fatores interatuantes na estrutura genética do fenômeno”. ${ }^{22}$

\footnotetext{
${ }^{16}$ QUIROGA A. apud FERNANDES, M.I.A., Op. cit., 1989, p.45/46.

${ }^{17}$ QUIROGA, A.P. Enfoques y Perspectivas en Psicologia Social. Buenos Aires, Ediciones, 1986.

${ }^{18}$ PICHON-RIVIÈRE apud QUIROGA, A..P. Op. cit., 1986.

${ }^{19}$ FERNANDES, M.I.F. Op. cit., 1989, p.43.

${ }^{20}$ PICHON-RIVIÈRE, E. Op. cit., 1986.

${ }^{21}$ PICHON-RIVIÈRE, E. Teoria do Vínculo. São Paulo, Ed.Martins Fontes, 1982.

${ }^{22}$ BAULEO, A. Op. cit., 1988, p. 106.
} 
O grupo, local em que as afetividades se expressam e as relações se concretizam, é o lugar privilegiado para investigar esses fenômenos. Ele é considerado como objeto de estudo para a compreensão do sujeito e da articulação entre suas determinações internas e determinações externas. O grupo passa a ser entendido como unidade de interação e de análise. 23

Para Bauleo apud Fernandes ${ }^{24}$, a vinculação entre o social e o individual pode ser estabelecida a partir de um recorte do grupal. O grupo é o 'lugar transitório', de mediação, imprescindível para investigar a relação 'Indivíduo-Sociedade’.

"Todo conjunto de pessoas ligadas entre si por constantes de tempo e espaço, e articuladas por sua mútua representação interna, configura uma situação grupal. Tal situação está sustentada por uma rede de motivações e nela interagem entre si, por meio de um complexo mecanismo de assunção e adjudicação de papéis. É neste processo que deverá surgir o reconhecimento de si e do outro, no diálogo e no intercâmbio permanente. Esta situação grupal constitui o instrumento mais adequado para essa aprendizagem de papéis (aprendizagem social), em que consiste a internalização operativa da realidade.” 25

No grupo, unidade interacional, são estabelecidos os processos de comunicação, troca de signos. A inclusão e a antecipação da resposta do outro na conduta do sujeito definem o processo de interação.

Para Fernandes, a unidade interacional pode ser definida como um sistema. Desse modo, uma relação vincular não se consolida apenas com o compartilhar de tempo, espaço, objetivo, se não houver uma organização interna. Tal organização requer um fundamento motivacional: a necessidade. Ela “está na base, é o ‘motor’ da relação com o outro, é o que lhe confere sentido." A partir dela, instala-se "a idéia de ação direcional (mútua internalização), que nasce com uma tarefa." ${ }^{26}$

Nesse sentido, a 'tríade' necessidade-objetivo-tarefa e a mútua representação interna (internalização recíproca, ou inscrição intra-sujeito da trama interacional) apresentam-se como princípios organizadores do grupo. “A tarefa é o conjunto de ações que permite chegar ao objetivo e satisfazer a necessidade. A tarefa é transformação de uma ausência, representada pela necessidade.” 27

Da inscrição interna em cada um dos sujeitos na situação interacional emerge o jogo de fantasias, expresso no grupo por mecanismos de atribuição e incorporação de papéis. "Num grupo cada membro projeta seus objetos de fantasia sobre outros membros do grupo. Encontramo-nos no que se refere ao campo grupal, com múltiplas transferências. Estas

\footnotetext{
${ }^{23}$ FERNANDES, M.I.A. Op. cit., 1989.

${ }^{24}$ Ibidem.

${ }^{25}$ PICHON-RIVIÈRE, E. Op. cit., 1986 , p.116.

${ }^{26}$ FERNANDES, M.I.A. Op. cit., 1989, p.46.

${ }^{27}$ Ibidem.
} 
emergem tanto em relação aos membros do grupo quanto em relação à tarefa e o contexto onde se desenvolve a ação grupal."28

Entendemos o grupo como cenário imediato da experiência, de determinação recíproca entre sujeitos, de interdependência entre o intrasubjetivo e intersubjetivo (sujeito e contexto vincular). Ele sempre carrega uma concepção de subjetivo.

A análise de grupos vai nos permitir, assim, investigar a infra-estrutura inconsciente das ideologias que se põem em jogo na interação grupal. As ideologias determinam o surgimento de confrontos entre subgrupos, já que nem sempre elas formam um núcleo coerente em cada sujeito e/ou em cada unidade grupal. Essa coexistência determina diferentes montantes de ambigüidade, que se manifestam como contradição.

Para Pichon-Rivière, as ideologias emergentes nos grupos são sistemas de representações, de pensamentos mais ou menos conscientes ou inconscientes com grande carga emocional. Freqüentemente assemelham-se a crenças religiosas, embora seus portadores considerem seus pensamentos como resultado de um raciocínio lógico. Representam fator fundamental na organização da vida, podendo ser transmitidas de pais para filhos, de professores para alunos por processos de identificação.

O conteúdo manifesto da ideologia pode ser compreensível ou não. Ao funcionarem de maneira mais ou menos inconsciente, elas constituem-se em barreiras que impedem a manifestação de novas descobertas na convivência grupal.

Nesse sentido, faz-se necessário analisar a infra-estrutura inconsciente das ideologias. Estas são formuladas em palavras; portanto, a análise das palavras ou da linguagem, análise semântico-semantística, constitui, além da análise sistêmica, uma parte fundamental na investigação das ideologias. ${ }^{29}$ Considera-se também fundamental a análise sistemática da ambigüidade das ideologias presentes no grupo que se apresentam em forma de contradição. As contradições tendem a levar a tarefa grupal a uma situação dilemática, a qual funciona como "defesa diante da situação de mudança”, 30

A tarefa prioritária no grupo diz respeito à elaboração de um esquema conceitual referencial operativo (ECRO) comum, condição básica para o estabelecimento da comunicação. A construção desse ECRO se dará a partir da reestruturação, do reajuste dos esquemas conceituais dos sujeitos envolvidos na relação, o que implica superação e, conseqüentemente, mudança da situação estabelecida.

A tarefa implícita do grupo está voltada para a elaboração de ansiedades relacionadas aos dois medos básicos emergentes nas situações de mudança, ou seja, medo da perda (ansiedade depressiva) das estruturas já estabelecidas e medo do ataque (ansiedade paranóide) na nova situação, provindo de estruturas nas quais o sujeito se sente inseguro por

\footnotetext{
${ }^{28}$ FERNANDES, M.I.A. Op. cit., p.54.

${ }^{29}$ PICHON-RIVIÈRE, E. Op. cit., 1986 , p. 93.

${ }^{30}$ Ibidem.
} 
carência de instrumentação. Estas duas ansiedades, coexistentes e cooperantes, configuram uma atitude de resistência à mudança que se manifesta pelo estereótipo, enquanto reprodução cristalizada de situações e de papéis vividos pelos membros do grupo (adaptação passiva). O rompimento da estereotipia permite a mobilidade de papéis no grupo, momento de aprendizagem (adaptação ativa).

Adaptação ativa à realidade e aprendizagem estão indissoluvelmente ligadas. À medida que o sujeito apreende o objeto e o transforma, "modifica-se também a si mesmo, entrando em um interjogo dialético com o mundo no qual a síntese que resolve uma situação dialética transforma-se no ponto inicial ou tese de uma antinomia, que deverá se resolvida neste contínuo processo em espiral. À medida que se cumpre este itinerário - objetivo e do grupo -, a rede de comunicações é constantemente reajustada, e só assim é possível reelaborar um pensamento capaz do diálogo e de enfrentar a mudança.” 31

A aprendizagem, na teoria pichoniana, é sempre aprendizagem de papéis em situação. Nesse sentido, a noção do papel torna-se relevante, à medida que busca expressar a mútua determinação entre relações sociais concretas e constituição da subjetividade. Entende-se que papéis em interação, expressão das relações concretas, são apreendidos de um modo especial pelo sujeito e será traduzido em atitudes, numa maneira peculiar de se vincular ao mundo. Estas atitudes poderão trazer novas qualidades às relações sociais estabelecidas.

Como já apontamos, os processos intersubjetivos não podem se dar sem a análise do mundo interno e, do mesmo modo, essa dimensão intra-sujeito ser compreendida se isolada do contexto vincular. Considerando as duas dimensões de fenômenos presentes nesses processos - o observável (explícito) e o das fantasias inconscientes (implícito) - no processo de interação, buscamos, enquanto investigadores, desvendar o acontecer implícito, ou seja, a "ordem de fatos subjacentes, submetida a um processo permanente de estruturação e desestruturação.” 32

Segundo Pichon-Rivière, todo processo implícito manifesta-se, dentro do campo de observação, pelo surgimento de uma qualidade nova nesse campo, a qual será denominada emergente. O emergente destaca-se como conceito por representar a articulação possível entre os âmbitos da intra e intersubjetividade. Expressa-se por um conjunto de fantasias inconscientes explicitadas através do processo de atribuição e assunção de papéis. Ao conceito de emergente relaciona-se diretamente aquele que pode ser considerado um dos pilares da teoria pichoniana: $o$ conceito de porta-voz.

"Porta-voz de um grupo é o membro que em um momento denuncia o acontecer grupal, as fantasias que o movem, as ansiedades e necessidades da totalidade do grupo. Mas o porta-voz não fala só por si, mas por todos; nele se conjugam o que chamamos verticalidade e

\footnotetext{
${ }^{31}$ Ibidem, p. 127.

32 Ibidem, p. 156.
} 
horizontalidade grupal, entendendo-se por verticalidade aquilo que se refere à história pessoal do sujeito, e por horizontalidade o processo atual que acontece no aqui e agora, na totalidade dos membros. O porta-voz pode desempenhar seu papel porque nele se dá uma articulação entre sua fantasia inconsciente - fantasia que segue um modelo primário - e o acontecer do grupo em que se insere. Esse encaixe permite a emergência do material que deve ser interpretado. A interpretação utilizará esses dois elementos; o vertical e o horizontal.”33

Vertical do sujeito e horizontal do grupo articulam-se no papel, tornando compreensível a dialética indivíduo-grupo, pela expressão do porta-voz. O sujeito porta-voz expressa um conflito vivido como seu, mas que por sua vez denuncia o conflito da situação interativa e da relação com a tarefa. Ele é "veículo de uma qualidade emergente que afeta toda a estrutura grupal e que, como sinal, nos remete às relações infra-estruturais, implícitas, nas quais estão comprometidos todos os integrantes do grupo.” 34

Assim, o emergente representa uma nova situação grupal, sendo o 'porta-voz' (o portador de algo que não lhe pertence totalmente) o 'explicitador' das fantasias inconscientes do grupo, desta forma, funciona como um radar, a partir de sua própria história de vida. "Utilizando uma expressão da linguagem popular, dizemos que o porta-voz é o alcagüete do grupo. Através de seu próprio segredo 'desocultado', nos faz participantes do acontecer implícito ou do conteúdo latente da fantasia grupal.”35

As contradições e ideologias presentes no grupo, o jogo de papéis, o rompimento da comunicação, a estereotipia no processo de aprendizagem, bem como os momentos de superação dos processos paralisantes podem ser detectados a partir de novas qualidades de situações emergentes. O emergente condensa vários dos indicadores do funcionamento grupal e nos permite levantar hipóteses acerca das fantasias grupais, dos processos inconscientes.

Tal análise nos permite ir além do âmbito dos pequenos para o dos grandes grupos, ou seja, para a dimensão institucional. A Instituição pode ser compreendida a partir de “uma problemática inter-grupal, portanto, passível de ser investigada a partir do plano grupal, seja no nível prático, seja no nível teórico-metodológico.”36

“A teoria pichoniana pensa a instituição a partir dos papéis possíveis de serem vividos (ocupados) na própria instituição.” Esta poderá ser investigada, principalmente, a partir do jogo de papéis (maior ou menor mobilidade) estabelecido nos grupos. ${ }^{37}$

A instituição pode ser pensada ainda como fato psíquico. Formulações teóricas de autores como Bleger, Enriquez e Kaës colocam em evidência a “ordem própria da realidade

\footnotetext{
${ }^{33}$ Ibidem, 1986 , p. 129.

${ }^{34}$ Ibidem, p. 165.

${ }^{35}$ Ibidem, p. 110.

${ }^{36}$ FERNANDES, M.I.A. Op. cit., 1989, p. 25.

${ }^{37}$ Ibidem, p. 7.
} 
psíquica mobilizada pelo fato institucional: mobilizada, trabalhada ou paralisada, e deve-se dizer também, apoiada na instituição.”38

Segundo Bleger, as instituições fazem parte da personalidade do indivíduo. "E, como tal, tem tamanha importância que a identidade é sempre - total ou parcialmente - grupal ou institucional, isto é: pelo menos uma parte da identidade é sempre configurada pela pertinência a um grupo, uma instituição, uma ideologia, um partido etc. Fenichel escreveu: Não há dúvida nenhuma de que as estruturas individuais criadas pelas instituições ajudam a conservar essas mesmas instituições'. Mas, além dessa interação indivíduos-instituições, as instituições funcionam sempre (em graus variáveis) como limites do esquema corporal e núcleo básico da identidade.” 39

Duas acepções são atribuídas ao termo Instituição, por Bleger: como conjunto de normas, regras e atividades agrupadas em torno de valores e funções sociais; e como definição de organização, ou seja, como uma disposição hierárquica de funções que se efetuam numa área delimitada. ${ }^{40}$

No seu entender, a instituição é comparável ao enquadramento da situação analítica, ou melhor dizendo, o próprio enquadramento pode ser considerado como uma instituição. Esse enquadramento define-se por um conjunto de constantes (não-processo), dentro do qual se desenvolvem os fenômenos, os comportamentos da relação terapêutica (o processo que é analisável, interpretável).

O “enquadramento é 'mudo’, mas nem por isso inexistente, formando o não-ego do paciente, à base do qual configura-se o ego. Este não-ego é o mundo fantasma do paciente, que se deposita justamente no enquadramento e representa uma meta-conduta.” 41

A parte psicótica da personalidade (não-ego) do paciente, ou seja, a parte indiferenciada não resolvida de vínculos simbióticos primitivos é depositada no enquadramento. Do mesmo modo, as instituições e as organizações são consideradas depositárias dessa parte psicótica. Nesse sentido, a dissolução ou tentativa de mudança dessas instâncias pode produzir diretamente uma desagregação da personalidade, já que a organização e o grupo são considerados a personalidade de seus membros.

Para Bleger, o "ser humano antes de ser uma pessoa é sempre um grupo, não no sentido de pertencer a um grupo, mas no sentido de que a sua personalidade é um grupo.”42

O grupo é considerado uma instituição sempre muito complexa, um conjunto de instituições, que tem, ao mesmo tempo, uma tendência a se estabelecer como uma organização com regras fixas. Além de ser um conjunto de pessoas que entram em relação entre si é,

\footnotetext{
${ }^{38}$ KAËS, R. A instituição e as instituições - Estudos psicanalíticos. São Paulo, Casa do Psicólogo, 1991, p. XVI.

${ }^{39}$ BLEGER, J. Simbiose e ambigüidade. Rio de Janeiro, Francisco Alves, 1988, p.313.

${ }^{40}$ BLEGER, J. O Grupo como Instituição e o Grupo nas Instituições. . In A instituição e as instituições - Estudos psicanalíticos. São Paulo, Casa do Psicólogo, 1991.

${ }^{41}$ BLEGER, J. Op. cit., 1988, p. 325.

42 BLEGER, J. Op. cit., 1991, p. 51.
} 
fundamentalmente, uma sociabilidade estabelecida sobre um fundo de indiferenciação ou de sincretismo.

Nesse sentido, entende que em todo o grupo há um tipo de relação que, paradoxalmente, é uma não-relação. Essa não-relação (sociabilidade sincrética), clivada da relação (sociabilidade por interação) e da parte organizada da personalidade (ego), fica depositada nas estruturas institucionais. O "nível da interação se organiza de uma maneira fixa e estável, mas a fixidez e a esterotipia da organização, por sua vez, baseiam também e, fundamentalmente, no estabelecimento do controle sobre a clivagem entre esses dois níveis, de tal forma que a sociabilidade sincrética se torna imóvel."^33

A necessidade de manter clivados esses dois níveis de sociabilidade, sincrética e por interação, pode explicar uma tendência à burocracia e à resistência à mudança nos grupos e organizações. Burocracia entendida quando os meios se transformam em fins e quando se deixa de lado o fato de se ter recorrido a determinados meios para atingir os fins perseguidos.

Nesse sentido, os objetivos explícitos pelos quais as organizações foram criadas, "correm o risco de passar para o segundo plano, colocando em primeiro plano a perpetuação da organização enquanto tal. E isso acontece não somente para proteger a esterotipia dos níveis de interação mas, fundamentalmente, para salvaguardar e assegurar a clivagem, o depósito e a imobilização da sociabilidade sincrética (ou parte psicótica do grupo).” 44

Vale ressaltar que a reação do grupo diante de uma experiência nova diz respeito tanto ao medo do que é desconhecido (a novidade), quanto ao medo do desconhecido que existe no interior daquilo que é conhecido. O "medo se produz diante do desconhecido que cada pessoa traz em si mesma sob forma de não pessoa e de não-identidade (ou de Eu sincrético).” Em outras palavras, "é o medo de não continuar a reagir com as regras estabelecidas que se deve assimilar enquanto pessoa; é o medo do encontro com uma sociabilidade que nos aniquila, enquanto pessoa e nos transforma num único meio homogêneo, sincrético, no qual cada um não poderá emergir do fundo enquanto figura (como pessoa), mas, ao contrário, permanece submerso nesse fundo, o que implica uma dissolução da identidade estruturada pelos níveis mais integrados do Eu, do self ou da personalidade.” 45

Para Enriquez ${ }^{46}$, as instituições são entendidas como elementos da regulação social global que se apresentam como conjuntos culturais (enquanto valores e normas instituídas), simbólicos (o objeto ideal a ser interiorizado) e imaginários (imprimindo desejos de afirmação narcísica e de identificação nas suas fantasias de onipotência ou na sua necessidade de amor). As instituições têm, quando entendidas deste modo, um objetivo de existência sobre a trama simbólica e imaginária nas quais se inscrevem. A família, a Igreja, os grupos educativos e

\footnotetext{
${ }^{43}$ BLEGER, J. Op. cit., 1991, p. 49.

${ }^{44}$ Ibidem.

${ }^{45}$ Ibidem, p.46.

${ }^{46}$ ENRIQUEZ, E. O trabalho da morte nas instituições. In A instituição e as instituições - Estudos psicanalíticos. São Paulo, Casa do Psicólogo, 1991.
} 
terapêuticos podem ser assim consideramos já que colocam o problema da alteridade ("aceitação do outro enquanto sujeito pensante e autônomo por cada um dos atores sociais que mantêm com ele relações afetivas e vínculos intelectuais”).

Ao serem analisadas, as instituições revelam um caráter paradoxal: por um lado, são lugares pacificados e expressam um mundo que funciona sob a égide das normas interiorizadas e que permite, apesar de não se ter um consenso total, um acordo para se levar adiante uma obra coletiva. "As instituições que facultam a entrada do homem num universo de valores são criadoras de normas particulares e de sistemas de referência (mito ou ideologia) que servem como lei organizadora tanto da vida física quanto da vida mental e social dos indivíduos."47

Por outro, as instituições são lugares que não podem impedir a emergência da violência que se estabelece a partir do momento em que normas, valores etc. se impõem independente da escolha de seus membros. As instituições já existiam e vão continuar a existir independente deles.

“A violência parece ser assim substancial para a vida institucional, na medida em que procede da legalidade que exige que os homens renunciem à satisfação das suas pulsões e na medida em que, fazendo isso, é capaz de reacender os combates entre os iguais e favorecer o desejo de transgressão das interdições." ${ }^{48}$

Entretanto, a violência institucional não se reduz à violência legal. Quando um grupo é instituído, novos mecanismos se instalam: projeção ao exterior por parte dos indivíduos de objetos internos; ataques contra vínculos institucionais, por parte dos indivíduos que utilizam eletivamente tipos primários de defesa (clivagem e rejeição); afirmações ditatoriais ou indiscutíveis, proliferação de mentiras tornam-se freqüentes, já que a própria instituição favorece as lutas pelo poder. ${ }^{49}$

Assim, se de um lado as instituições servem como lei organizadora para a vida física, mental e social dos indivíduos que delas participam, por outro, esforçam-se para mascarar as condições de seu nascimento (violência fundadora). Elas defendem a esfera do 'sagrado' e do 'profano', pronunciam interdições, desenvolvem o sentido da culpa que são enunciados como lei de estrutura e não como violência . "Se renunciam formalmente a violência de todos contra todos, instauraram a violência legal. ... Sabe-se, com efeito, que a interdição suscita o desejo da transgressão, que o conflito e a rivalidade entre os irmãos, membros da instituição, podem sempre romper a barreira instaurada pela necessidade de consenso."

\footnotetext{
${ }^{47}$ Ibidem, p. 53.

${ }^{48}$ Ibidem, p. 55.

${ }^{49}$ ENRIQUEZ, E. Op. cit., 1991.

${ }^{50}$ Ibidem, p. 55
} 
Aquilo que envolve a convivência, seja nos pequenos, seja nos grandes grupos além de tudo que diz respeito às determinações econômicas, sociais, políticas e históricas - diz respeito e se manifesta principalmente por aquilo que significa estar com o outro.

Desta convivência emergem algumas questões, que buscamos considerar ao lançar nosso olhar sobre o cotidiano dos trabalhadores em saúde mental: como abrir mão dos ‘desejos’, incluir os ‘desejos’ do outro e daquilo que é instituído sem perder os seus próprios? Como compreender e assumir concepções tão diferentes se estas podem desestruturar as já estabelecidas?

\section{3 - O percurso de análise}

Ao lançarmos nosso olhar sobre os grupos de supervisão do Projeto de Formação, orientados, principalmente, pelo referencial pichoniano em Psicologia Social, procuramos constatar/revelar contradições referentes à inserção dos trabalhadores em saúde mental no contexto da construção de novas práticas.

Formulamos hipóteses e atribuímos significados acerca do funcionamento grupal, procurando decodificar o sentido do emergente em cada sessão, em cada grupo e na totalidade dos grupos de supervisão.

Sustentamos nosso trabalho de decodificação no referencial psicanalítico, aplicando, deste modo, os conhecimentos dele proveniente num âmbito que transcende os limites da psicanálise clínica. Sabemos que a investigação em psicanálise é inseparável da prática clínica. Sabemos também que seu valor social enquanto terapia é limitado, por não atingir grande parte de pessoas que poderiam dela ser beneficiadas.

Segundo Bleger, "a nenhuma técnica de investigação (do método clínico ou do método experimental), em nenhuma disciplina científica, se lhe exige que resolva um problema sobre o plano social. O único que se espera é que contribua com conhecimentos sobre os quais possa se basear uma planificação científica de alcance e extensão social. Reconhecer as limitações sociais de um procedimento de laboratório não é nenhum desmérito para nenhuma técnica, porque, justamente, seria questionar as condições básicas nas quais resulta factível levar a cabo uma investigação de laboratório.” 51

Desse modo, podemos considerar que a "transcendência social da psicanálise reside fundamentalmente em sua capacidade de ser um método de investigação dos fenômenos psicológicos que, como tal, contribui com conhecimentos valiosos sobre as leis psicológicas

\footnotetext{
${ }^{51}$ BLEGER, J. Psico-higiene e psicologia institucional. Porto Alegre, Artes Médicas, 1984, p.112.
} 
que regem a dinâmica tanto da saúde como da doença e nos permite também compreender e valorizar os efeitos de determinados acontecimentos sobre a formação e evolução da personalidade." ${ }^{22}$

A aplicação da psicanálise não se volta unicamente ao campo de estudo de obras literárias ou artísticas, mas também tem-se mostrado relevante no caso de distintas manifestações culturais, de distintos comportamentos ou atividades e também no estudo da interação indivíduo-sociedade. "A psicanálise aplicada reduz também a complexidade dos fenômenos, como também o faz a psicanálise clínica, mas numa direção muito definida: na amortização do impacto direto da relação transferencial-contratransferencial, que faz com que alguns problemas (como os da psicose) possam ter sido primeiro investigados mais profundamente com o procedimento da psicanálise aplicada."

Ainda segundo Bleger, não é possível ser investigador se não se extrair os problemas da própria prática e da realidade social que se está vivendo em um dado momento.

Os grupos de supervisão analisados neste trabalho fazem parte da realidade de implantação de novas práticas em saúde mental. Deste modo, atribuimo-lhes, neste trabalho, um duplo sentido: como espaço de investigação, de procedimentos, de coleta de dados; e, ao mesmo tempo, lugar de transferências, de depositação das expectativas e de investimento psíquico dos trabalhadores em saúde mental.

Considerando tais questões, a partir da análise sistemática e de interpretação dos emergentes grupais, fizemos um trabalho de 'recortes' e 'junções'. Ao destacar temas e situações sugestivas do acontecer implícito do processo de implantação, buscamos compor um cenário no qual trabalhadores em saúde mental estão inseridos.

$\mathrm{O}$ ato de analisar pode ser entendido como um ato de examinar as partes de um todo, investigando sua natureza, suas proporções, suas funções, suas relações e assim por diante. É um ato de decompor fatos que possam nos levar a novas sínteses.

$\mathrm{O}$ ato de interpretar, segundo Pichon-Rivière, tem um caráter de elaborar hipóteses acerca das fantasias. Tais hipóteses não dizem respeito a um critério tradicional de verdade, mas sim, à produção de significados referentes ao processo grupal. Inclui, explícita ou implicitamente, um critério de realidade (esquemas referenciais), a partir do qual se analisa a situação do grupo.

Consiste na decodificação do sentido do emergente, como "uma hipótese, formulada a partir do explícito, a respeito do acontecer implícito; o vertical do porta-voz, que lhe permite assumir o papel, e o horizontal do grupo. Muitas vezes, essa horizontalidade, acontecer grupal, só pode ser decodificada pelo somatório do verbalizado ou atuado por vários porta-vozes." 54

\footnotetext{
52 Ibidem, p. 110.

53 Ibidem, p. 114.

${ }^{54}$ PICHON-RIVIÈRE, E. Op. cit., 1986, p. 165.
} 
Nesse sentido, ao formular as hipóteses sobre o conteúdo implícito do explicito, o intérprete, a partir da matéria prima cuja natureza está sendo investigada, produz um sentido, uma interpretação. Produzir uma interpretação, segundo Fernandes, nos remete ao sentido originário que a constituição da palavra indica. "Pro-dução é levar para adiante, para o revelado, o que se encontra retirado. Nesse sentido, o produtor 'se presta entre' a matéria-prima e o produto como o espaço dessa transformação. Esse 'prestar-se entre' é o que diz o termo inter-pretar. $" 55$

A análise e interpretação do material colhido nesse trabalho, como já apontamos, se deu no sentido de desvelar ambigüidades e contradições, sejam internas de cada grupo e/ou de grupo para grupo, por nós entendidas, na maioria das vezes como "nós cegos", como dicotomias do pensamento e como lacunas entre a organização da instituição e as idéias, as falas e as práticas envolvidas na implantação da rede substitutiva em questão.

${ }^{55}$ FERNANDES, M.I.A. Op. cit., 1989, p. 76. 


\section{4 - UM OLHAR SOBRE A REDE SUBSTITUTIVA: OS INTERSTÍCIOS DA PRÁTICA}

Contradições, ambigüidades, angústias: assim podemos nomear algumas das manifestações que dizem respeito à convivência coletiva no cotidiano do trabalho de implantação da rede substitutiva.

Um duplo sentido pode ser atribuído a elas. Representam as dicotomias do pensamento, as lacunas entre instituição, idéias e práticas, que transformam essa convivência num mundo de indiscriminação e paralisia. E, ao mesmo tempo, são as conseqüências, talvez inevitáveis, de um novo momento da reestruturação e superação da assistência psiquiátrica tradicional, que necessitam serem enfrentadas.

Se, de um lado, as novas práticas trazem benefícios concretos, muitas vezes mudando o percurso de vida de seus beneficiários, por outro, o tipo de inserção do trabalhador na instituição, caracterizado pela constante luta contra formas instituídas, é repleto de angústias e dificuldades de entrosamento, o que impede a apropriação e sistematização do saber por parte desses criadores dos novos conhecimentos

Ao lançarmos nosso olhar sobre o 'desenrolar' dos grupos de supervisão, identificamos alguns temas que se mostraram elucidativos nesse sentido. As diferentes facetas reveladas desses mesmos temas nos trazem a imagem de um contexto extremamente complexo e rico de heterogeneidades, gerador de dificuldades, incertezas, mas também, propiciador de possibilidades: aquilo que num grupo de trabalhadores poderia ser entendido como empecilho ao andamento do trabalho, num outro expressa a possibilidade de crescimento da equipe e concretização da implementação de novas práticas.

Para tanto, destacaremos, como eixo de análise, quatro destes temas:

1 - concepção de loucura no trato ao doente mental, entendida como fundamentação teórica, ideológica e política dos modelos inspirados pelo movimento antimanicomial; 
2 - equipe multiprofissional, emblemática e entendida como princípio para a organização de novas propostas que buscam o convívio com a diferença;

3 - formação dos sujeitos/trabalhadores responsáveis pela concretização das novas práticas;

4 - construção de novas práticas inspiradas nos ideais antimanicomiais.

As questões emergentes e relacionadas a estes temas revelam-se, principalmente, a partir de múltiplas contradições evidenciadas por sentimentos de impotência/onipotência, tendo como efeito a (im)possibilidade de criação daquilo que vem a ser os "ideais" do movimento antimanicomial. Ao discorrermos sobre tais temas, destacaremos trechos dos dados de observação, teceremos comentários e levantaremos pontos que consideramos relevantes para a compreensão de tal contexto.

\section{1 - A concepção de loucura no trato ao doente mental}

O movimento antimanicomial, como já apontamos no $1^{0}$ capítulo, tem exercido importante influência na criação de uma cultura contra-hegemônica em nosso país, a partir do entendimento de que o doente mental deve ser visto como cidadão e não apenas como objeto de intervenção psiquiátrica. Desenvolve uma crítica radical à psiquiatria moderna, propõe a reestruturação dos serviços de saúde mental, busca mobilizar diferentes setores da sociedade civil em torno dos direitos à cidadania dos portadores de transtornos mentais, denuncia atos de violência, discriminação e exclusão que sofrem não somente os 'pacientes psiquiátricos', mas também aqueles que não servem à estrutura do sistema capitalista de produção.

A tentativa de abandono da concepção clássica de doença mental e da abolição da internação manicomial carrega, como conseqüência, a possibilidade de diferentes formas de atuação no trato ao doente mental. Os espaços de intervenção ampliam-se para além daqueles considerados terapêuticos tradicionalmente, no sentido estrito do termo (psicoterapias, consulta médica com indicações e uso de medicação etc.), para outros que transcendem os limites da instituição psiquiátrica (oficinas de trabalho, passeios, atividades artísticas e de expressão corporal). Nesse contexto surge a questão: o que vem a ser terapêutico? 
Terapêutico $X$ não terapêutico se confundem, já que o princípio fundamental do novo modelo é reinserir o 'doente mental’ no espaço social e, para isso, é necessário priorizar a convivência em diferentes espaços sociais. O terapêutico está ora relacionado com o sentido estrito do termo, ora transcendendo o espaço da instituição saúde.

"Interessa discutir o que é terapêutico para o psicótico. Minha vontade era fazer um processo de supervisão aonde se pudesse trabalhar isso".

“... para mim é extremamente fácil num grupo de terapia ... Se eu converso com o paciente aqui fora (da situação de atendimento formal) ... tem hora que eu tenho vontade de chorar junto. Se eu estou fora eu sinto que o meu envolvimento é maior com o paciente ... Quem é que decide até quando esse paciente fica aqui (no hospital dia) ... .é muito difícil. (..).Qual o jeito de lidar com isso?”

Perguntas relacionadas à consecução do trabalho são sistematicamente formuladas: indagações sobre tipos de intervenção (se há nelas sentido terapêutico), se existe ou é necessário utilizar uma técnica específica, se é necessário ter a formação técnica. Poderíamos traduzir estas em outras perguntas que se fazem presentes no contexto de implantação: o que é saber? O que se sabe nesse trabalho? Quem sabe? Saber $X$ não saber, passa a ser uma questão.

"A gente nunca sabe direito qual o objetivo do tratamento, eu acho que é o objetivo de cura ... Que tipo de melhora eu posso esperar do psicótico? ... O que esperar num lugar desse (num hospital dia) ...”

“... O que é mais importante escutar? ... Qual o limite da intervenção dos outros funcionários (os não técnicos)? O que é ser terapeuta fora da sala? E o que exigir dos funcionários?”

" Os riscos que a pessoa se coloca sem conhecer um psicótico pode desencadear reações ... Tendo conhecimento e sabendo lidar com a coisa o resultado é maior. Eu fico preocupado com soltar um psicótico e em como ele vai reagir. Acho que alguém mais especializado trabalharia melhor com isso. Dá angústia, muitos psiquiatras sofreram agressões."

"Acho que o que assusta muito é o delírio .... e se o psiquiatra entra na loucura do paciente e não sabe como lidar com isso?”

“ Num hospital psiquiátrico tinha uma mulher, uma enfermeira, que só apanhava, mas também ela pedia isso. Acho que não é preciso ter uma formação médica específica para se trabalhar com os psicóticos"

A experiência de ‘não saber’ faz parte do cotidiano dos trabalhadores, seja pela falta de um terreno teórico seguro que ainda está por ser construído, seja pela condição precária 
de formação. A experiência pessoal e a auto-imagem decorrente é a de impossibilidade de apropriação do saber, contrariamente ao que se espera do trabalho em equipe, ou seja, a idéia de que a conjunção de diferentes saberes e experiências possibilitaria a 'criação do novo'. Apesar do discurso vigente, segundo o qual a construção de novas práticas se dá coletivamente, estas são desenvolvidas a partir de expectativas de que existam saberes/verdades, capazes de dar conta desse trabalho.

Embora expectativas façam parte de todo processo de mudança (representam a antecipação dos objetivos perseguidos), algumas vezes apresentam-se como paralisantes na constituição das novas práticas em saúde mental. O fato de se buscar a destruição de um modelo psiquiátrico hegemônico, sem haver um conhecimento teórico-técnico seguro que possa substituir o antigo, aliado à cisão instalada nos serviços entre teoria e prática, entre reflexão e ação, cria a ilusão aos trabalhadores de que haja um saber constituído, ou uma técnica capaz de dar conta das novas práticas, cuja posse não lhes pertence.

Podemos dizer que o desconhecimento em lidar com pacientes 'psicóticos' dentro da 'nova lógica' antimanicomial, as dúvidas relacionadas à delimitação do espaço terapêutico e à própria formação do profissional apresentam-se como fontes de angústia.

A angústia pode ser entendida como encobridora dos conteúdos emergentes no cotidiano do trabalho. Em outros termos, o medo da loucura e de identificação com ela, associado, simultaneamente, ao medo de perda da identidade profissional apresenta-se muitas vezes como insuportável.

Esse medo pode ser associado à indiscriminação emergente da falta de delimitação sobre o que vem a ser a 'doença mental/loucura' e as formas de intervenção sobre o sofrimento por ela causado (nova modalidade de compreensão do processo saúde/doença).

A noção de limite parece ser peça chave na construção das novas práticas. Por um lado, carrega uma conotação negativa ao expressar a barreira estabelecida socialmente entre 'loucos’ X 'não-loucos' (a exclusão do convívio social dos 'doentes mentais') e a pouca efetividade de ações profissionais isoladas e de suas técnicas (limitações da prática), na ‘recuperação' desses mesmos excluídos (reinserção no contexto social).

Por outro lado, no âmbito da organização psíquica, sabemos que a definição de limites é fundamental para a constituição e estruturação da subjetividade e da convivência coletiva. O limite, nesse sentido, apresenta uma conotação positiva, por representar a possibilidade de organização ao caos que geralmente emerge da indiscriminação.

Os trabalhadores estão, assim, diante de conflitos a serem superados na busca pela superação dos manicômios, os quais dizem respeito aos limites de exclusão e de normatização de condutas que definem a doença mental. Apesar de limites, num sentido amplo, implicar cerceamentos e até mesmo exclusão, eles são necessários. Desse modo, não se trata de 
aboli-los, mas de buscar uma nova delimitação, um novo rearranjo de significações que não sejam contraditórios aos princípios da luta antimanicomial.

Quais seriam os limites entre usuário X profissional, psicose X neurose, razão X desrazão/doença mental, espaço formal X espaço informal, eficiência X ineficiência de técnicas e procedimentos de atendimentos?

Podemos abordá-los a partir de diferentes aspectos. Sobre a relação trabalhadores $X$ usuários, ao considerarmos a técnica, a teoria que a fundamenta e a relação estabelecida entre os próprios trabalhadores, aliada aos princípios antimanicomiais de nãoexclusão incluídos nas ações dos serviços de saúde, podemos pensar no limite (ou sua ausência) relacionado às dúvidas que dizem respeito ao como lidar com as atitudes dos usuários dos serviços. Dentre estes, merecem destaque os 'psicóticos', por apresentarem como característica básica a falta de limite e discernimento para com as regras básicas de convivência.

“...é preciso saber os limites. Não é entrar na loucura, é uma incursão nela. O limite é tirado no momento. O terapeuta pode se misturar com o louco e enlouquecer junto. O louco é de maneira geral mal recepcionado. Muitos dos casos de agressão ocorrem pela má recepção. Tem que ter um feeling para perceber o que está acontecendo com o cara"..

“ ... como a gente escuta quanto o paciente diz: não venho de manhã ou não consigo acordar cedo ... (sobre o paciente M.) como é que faz, atende a hora que ele vem?

Outros profissionais sobre o mesmo paciente:

“Eu tomei uma atitude ... depois ele ansiosamente me catava na sala ... sei lá, alguma situação especial eu até poderia atender, mas fora disso eu não iria atender.

“.. pro tratamento dele (a participação da família) é uma questão terapêutica ... me digam o que é melhor para ele.”

Podemos supor que o 'melhor' que se busca para os usuários do serviço diz respeito a um outro entendimento de suas condutas, que não repetisse a lógica do saber psiquiátrico tradicional, baseada em critérios de exclusão, normatização, classificação e medicalização. Entra em questão no âmbito das práticas um outro tipo de oposição: modelo médico X modelo 'não-médico'. Oposição entre o campo de ação hegemônico nos serviços de saúde, herdeiro da medicina social ${ }^{191}$, e outro que vem se constituindo na delimitação de um campo de saúde mental, o qual conjuga diferentes áreas do saber.

191 Só é possível compreender o "nascimento da psiquiatria brasileira a partir da medicina que incorpora a sociedade como novo objeto e se impõe como instância de controle social dos indivíduos e de populações. É no seio da medicina social que se constitui a psiquiatria. Do processo de medicalização da sociedade, elaborado 
Do confronto entre áreas específicas do saber, o qual permeia a relação entre trabalhadores $X$ usuários, decorrem questões relacionadas a outro tipo de limite que diz respeito à eficiência $X$ ineficiência de técnicas e procedimentos dos atendimentos. Estes (procedimentos e técnicas) associam-se muitas vezes, no cotidiano dos novos equipamentos, ao (re)estabelecimento e preservação da identidade profissional.

Dentre os recursos técnicos de intervenção dos trabalhadores em saúde mental, podemos destacar aqueles que privilegiam abordagens psicanalíticas ${ }^{192}$ e grupais, apesar da predominância do modelo médico nos atendimentos. Este se faz presente ora como negação, ora como salvação.

“...o modelo médico me salva de vez em quando ... Eu estou muito identificada com eles (psicóticos) ... eu percebi que o modelo médico não abarcava a situação. O pessoal vinha muito para pedir remédio. A X (psicóloga) ajudou bastante para mudar essa minha imagem .... Muitos pacientes vêm com um familiar que fala no lugar dele. A família entra muito em cima não vê que o psicótico traz por si só os conteúdos. Tive um caso de uma mãe que vinha pedir remédio para deixar o filho mais quieto. (...) Tem alguns que têm toda a possibilidade de trabalhar e tem outros que em geral entram em pequenas crises, mas que algum trabalho é possível. Tem um lá que muda de humor muito rápido. Já trabalhei com grupo de neuróticos, mas com os psicóticos eles ficam esperando uma resposta imediata.

“Eu tenho dúvida quanto o HD (hospital dia), o que atender? Eu pensei que com o remédio eu pudesse dar uma solução para o paciente , mas não é bem assim. O sintoma não passa e eu não sei o que fazer."

“ O medicamento só não resolve. É isso o que se percebe. ... é difícil conter a ansiedade , não só do grupo mas também de quem medica".

Muitas vezes, ao questionamento sobre qual saber técnico deve ser utilizado como forma de tratamento, busca-se como resposta as 'terapias alternativas' principalmente aquelas que privilegiam o trabalho corporal $^{193}$ :

e desenvolvido pela medicina que explicitamente se denominou política, surge o projeto - característico da psiquiatria - de patologizar o comportamento do louco, só a partir de então considerado anormal e, portanto, medicalizável.” MACHADO, R. et al. Danação da Norma: Medicina Social e constituição da psiquiatria no Brasil. Rio de Janeiro, Ed. Graal, 1978, p. 376.

192 A abordagem psicanalítica, como já mencionamos, está relacionada com a formação de grande parte dos trabalhadores em saúde mental, principalmente psicólogos. Sob outro ponto de vista, no contexto da reforma psiquiátrica mundial, começam haver tentativas de conciliação entre psiquiatria e psicanálise, a partir da ‘explosão’ psicanalítica ocorrida na França após a II Guerra Mundial. Inicia-se, nesse época, um movimento que busca introduzir a psicanálise nas instituições, inclusive nas psiquiátricas.

${ }^{193} \mathrm{O}$ trabalho corporal tem se mostrado extremamente relevante no contexto das práticas substitutivas. Moffat, em Psicoterapia do Oprimido, Cortez Ed., 1983,p.21-24, descreve o corpo como maneira de 'ser-no mundo', o primeiro instrumento e ferramenta para modificar este mesmo mundo - é por ele que passa grande parte da dor e do medo - e entende que a nossa cultura abstrata e dissociada o nega prontamente. Ao abordar o nível corporal do paciente psiquiátrico internado argumenta: “...o hospício é um submundo onde não há tarefas, ou seja: a única tarefa ou "papel” que se exige do internado é que "trabalhe” de paciente, de "louco", respeitando 
“ No começo a gente nem pensava que as pessoas iam se ligar, mas com o tempo houve um processo, num crescente ... A coisa do corpo era muito forte. ... É um trabalho com 'tai chi', há pessoas de todas as idades, é impressionante como o pessoal vem mesmo, a sala estava lotada da última vez. O trabalho com o corpo está surtindo efeitos."

“Eu gosto de ver a coisa evoluir, e com psicótico a coisa é muito lenta. Fiquei aqui só com 'tai chi' e a jardinagem. ... Eu fiz um curso de essências florais e é aqui que vai ser aplicado.”

“ A gente pensa que atividade é não conversar, mas não é assim, o uso do material facilita o vínculo. A vinculação através do fazer é mais fácil; mas pode haver grupos em que só se conversa."

O dispositivo grupal nesse contexto tem um destaque especial. É preconizado como forma ideal de intervenção e terapêutica nas instituições inspiradas pelos princípios antimanicomiais, seja pela possibilidade de cobertura de demanda, seja pela instalação de convivência da diferença, ou ainda pelo lugar que ocupou tradicionalmente no contexto de reforma psiquiátrica no âmbito mundial. ${ }^{194}$ Apesar da importância institucional nem sempre é visto pelos trabalhadores como forma ideal de trabalho. Sobre o atendimento em grupos:

S: "era uma furada esse grupo, a gente fingia que atendia, eles fingiam que eram atendidos.

R. Era colocar a cada semana um grupo de pessoas numa sala.

S. Era treino de ficar louco.

seu diagnóstico, apresentando apenas aquelas alterações que a ciência afirma que ele deve apresentar.. O ócio, quando é maciço, desorganiza o sentido do ciclo do dia, do transcurso da semana, e leva o internado realmente a ter como tarefa a estruturação de seu delírio. O esquema corporal se impregna dessa atitude de um eterno deambular, as pessoas tornam-se arqueadas, adquirem um passo lento, como quem " não vai a lugar nenhum”, olham sem olhar, pois já olharam os mesmos detalhes do lugar milhares de vezes. A sensação que comunicam os internados é a de zumbis, de corpos sem inserção na realidade, ou seja, sem uma tarefa que organize a dinâmica de seu esquema corporal. (...) com o corpo e através dos anos o internado vai modelando sua estratégia de vida, de sobrevivência (ou supervivência) neste ambiente. Isso vai deste atitudes e deformações corporais que constituem toda uma representação mímica de seu tema de delírio (nas psicoses graves) até a somatização de pequenos transtornos que conferem vantagens secundárias aos enfermos chamados "lúcidos”."

${ }^{194}$ A utilização do dispositivo grupal passa a fazer parte de várias experiências que buscavam a 'humanização' do atendimento a pacientes psiquiátrico. Na Inglaterra, 1929, Sullivan transforma seu enfoque terapêutico voltando-se para "a integração dos pacientes em sistemas grupais, sendo mantido o serviço segundo a perspectiva do inter-relacionamento entre grupos” (Birman e Costa, Op. cit., 19 p.30) Na década de 40, Menninger, desenvolve o tratamento de pacientes mentais em pequenos grupos, buscando facilitar a ressocialização deles, a partir da discussão compartilhada nos grupos sobre os problemas de seus membros e as possíveis soluções. Maxwell Jones, precursor das comunidades terapêuticas, nos primeiros momentos de sua experiência, organiza os internos de hospital psiquiátrico em grupos de discussão e grupos de atividades. Para ele a idéia de comunidade terapêutica pautava-se na tentativa de "tratar grupos de pacientes como se fossem um único organismo psicológico.” (AMARANTE, Op. cit. 19 p.30) No Brasil, a publicação na década de 80, da "Proposta de trabalho para equipes multiprofissionais em unidades básicas e em ambulatórios", pela Coordenadoria de Saúde Mental do Estado de São Paulo, privilegiava o atendimento grupal a ser desenvolvido pelas equipes multiprofissionais. 
A. A gente tem que atender a demanda, então coloca um monte de gente numa sala e fica refletindo.

V. No final não era um grupo, a gente anotava as queixas de cada pessoa.

A idéia de se fingir que atende e os usuários fingirem que são atendidos, independentemente de ser em grupos, diz respeito, muitas vezes, à impossibilidade de os trabalhadores terem maior clareza, ou se apropriarem, dos conteúdos propositivos do novo modelo e de alguns dos fundamentos sobre os recursos técnicos nele embutido. Desse modo, tais recursos podem ser utilizados simplesmente como forma deles cumprirem sua função profissional, independentemente dos efeitos esperados.

Decorre daí um sentimento de impotência do trabalhador que se acentua ainda mais quando ele se encontra diante da fronteira entre loucura/doença mental X saúde mental. Este limite, contraditório com as propostas antimanicomiais, parece estar embutido na representação corrente de que ao doente mental podem estar reservadas apenas algumas melhoras e nunca a possibilidade de sair de um lugar de 'invalidez'. Essa compreensão desliza e eles também não vêem saída para a sua ‘invalidez’ profissional. ${ }^{195}$

O sentimento de 'invalidez' profissional ou de 'inutilidade' do trabalho é acentuado pela 'crença' de que sua ação, principalmente a desenvolvida com psicóticos, apenas pode amenizar o sofrimento mental. Faz-se presente a idéia da 'cura', relacionada à volta ao estado de normalidade e herdada do modelo médico, contraditória ao discurso que permeia o movimento antimanicomial e que fundamenta a construção desse novo modelo. A idéia predominante parece ir no sentido de considerar que entre os neuróticos isto seria possível, mas o psicótico nunca seria uma pessoa com ‘vida normal’, mesmo sendo bem atendido.

Nesse sentido, podemos afirmar que aquilo que se tenta combater no plano das idéias e ações propostas pelo movimento antimanicomial, muitas vezes, se reproduz no cotidiano do trabalho que se propõe alternativo.

195 A diferença entre "neuróticos” e "psicóticos” seria uma questão de qualidade, o que definiria limites para reabilitação dos pacientes que se 'encaixariam' no segundo grupo e, ao mesmo tempo, limitaria os resultados das ações realizadas no âmbito do trabalho. Neste sentido, se a doença é o limite, o trabalho pode ser inútil. 
Além disso, o sentimento de inutilidade parece estar assentado também no ideal do suposto saber existente em algum lugar, mas que dificilmente poderá ser apropriado.

“Eu fico muito angustiada porque falta muito para saber como ele (o psicótico) é.”...

"Sabe, eu trabalho há 17 anos na rede e ainda hoje eu tenho uma angústia, tenho até vergonha de falar, mas até hoje eu não sei o que é uma criança psicótica. Será que eu nunca achei uma criança psicótica ou será que eu nunca consegui discriminar, é falta no meu trabalho? Tem gente que consegue trabalhar muito bem isso, consegue discriminar e eu tenho vontade de discutir isso aí, porque eu não enxergo isso?”

"Eu me sinto profundamente identificada. A gente não sabe como trabalhar o psicótico. ... Fiquei pensando quem são esses psicóticos, quem trabalha com eles; mas entre as pessoas aqui parece que nós não temos essa prática.”

"Ouvi dizer que os psicóticos não trabalham com psicodramatistas, mas eu nunca participei; eu estou perdida. ... Os relatos que eu tenho é na linha psicodramática; tenho receio de fazer isso sem supervisão, mas não faço idéia até onde se pode chegar.”

Além das limitações encontradas na atuação prática, das representações que dizem respeito à 'doença mental' e suas possibilidades de 'cura', podemos depreender desse contexto um processo de identificação dos trabalhadores com seus 'pacientes psicóticos'. Algumas vezes ambos se confundem, como podemos perceber na fala acima: não é o psicótico quem trabalha com psicodramatistas, mas o contrário. Quem está no lugar do usuário é o próprio trabalhador.

Outro fato que chama a atenção diz respeito à categorização do doente mental. 'Psicótico', passa a ser o termo que identifica/categoriza os usuários atendidos nos equipamentos específicos de saúde mental, mesmo que não se saiba exatamente ‘o que’ isto significa na concepção embutida no novo modelo. Transcreveremos abaixo um trecho de sessão, em que dúvidas em relação a essa categorização, associada muitas vezes à falta de formação mínima e às incertezas dos ideais antimanicomiais levam o grupo a um estado de indiscriminação, confusão e angústia.

A. ${ }^{196}$ - “ Não seria melhor a gente ver a parte teórica sobre o que é o psicótico?

${ }^{196}$ As letras no início do diálogo são aleatórias e estarão presentes sempre que reproduzirmos trechos de uma mesma sessão de supervisão. 
Este pedido diz respeito a um não saber definir o tipo de clientela a ser atendida nas unidades substitutivas ao hospital psiquiátrico.

Supervisor - “Tudo bem, o que vocês acham que é um psicótico?”

(Silêncio muito grande)

F. - “A idéia que eu tenho de psicótico é uma pessoa que está fora da realidade, não consegue ter limites, e se ele não tem limites, ele acaba se perdendo.”

W.- "E o que quer dizer psicótico? A palavra em si..."

M. - "Psicose, bom, 'ose' é doença, não é? Acho que é doença da cabeça. Doença da psique.”

Este trecho, por um lado, se refere à 'loucura' do paciente atendido, mas nos remete também a outro tipo de loucura que se instala, relacionada ao contexto institucional. Esta diz respeito a um conjunto de conteúdos e saberes não claramente constituídos para a implementação de um novo modelo em saúde mental e se expressa pela falta de limites e perda da noção de realidade. Por outro lado, revela certa precariedade de formação, naquilo que diz respeito ao conhecimento básico relacionado à doença mental e que possibilite algum nível de intervenção técnica.

É importante frisar que muitos desses trabalhadores não têm formação em saúde mental até por terem vindo de áreas onde esta questão não se coloca como relevante (por exemplo: enfermagem, serviço social, fonoaudiologia). ${ }^{197}$

Silêncio

M. “Quando a pessoa não tem as suas áreas de equilíbrio, o espiritual, o corporal, é fogo né? Não gosto muito de lidar com rótulo, é difícil lidar com o rótulo. (...) Então eu me pergunto: que direito a gente tem de diagnosticar, pra quê? Sabe?

Z. - "Eu sempre tive uma resistência absurda com termos. Na verdade, independente do que ele seja, o fundamental é perceber o ser mesmo, o que está acontecendo, até você conseguir juntar as partes. Na medida que a gente procurar entendê-lo no sentido da vida, poder ajudar aquela pessoa naquele momento, do que você é capaz. Às vezes você não é nem um profissional. Às vezes um garçom, um pipoqueiro ajuda muito mais."

W. - "Mas eu acho que é legal que a gente saiba o que é um psicótico, um neurótico. É também um preconceito não querer falar sobre um psicótico, sobre o que é ser psicótico. Se eu sou

197 Embora alguns dos equipamentos aqui considerados, HD por exemplo, terem exigido comprovação de experiência profissional no atendimento a psicóticos de seus trabalhadores, esta, em muitos casos, não foi suficiente para implantação de novas práticas, até mesmo porque a formação universitária não tem oferecido uma base teórico-técnica que dê conta desse tipo de ação. Muito pelo contrário, este tipo de formação está também em construção, do mesmo modo que as práticas a que está referido. 
professor, as pessoas vão falar o que é ser um professor, mesmo que eu não me sinta um professor. Entender a nível teórico o que é um psicótico, assim como é um neurótico, um garçom, uma prostituta.”

O diálogo acima faz referência aos ideais antimanicomiais: 'não rotular', 'tentar compreender o paciente de uma forma mais abrangente', mas ao mesmo tempo, revela a angústia decorrente da crença sobre a existência de uma forma correta ou um saber que possa dar conta desses ideais.

A pergunta relativa ao 'para quê’ diagnosticar retira o lugar e a possibilidade de intervenção do profissional ser orientado por algum referencial (limites). Sua própria identidade fica sob suspeita, pois tanto faz ser psicólogo, médico, assistente social, pipoqueiro ou garçom para atender o doente mental. Nesse sentido, a angústia se acentua e os ideais antimanicomiais são entendidos de forma a não permitir a discriminação de diferentes papéis e lugares: tanto faz ser psicótico, professor, garçom ou prostituta, pois fazer essa discriminação é estar 'praticando' o preconceito. Pensando desta forma, ser profissional ou psicótico dá no mesmo.

A: - "De repente falar sobre psicótico parecia bobagem, né? Mas já que não deveríamos discriminar o psicótico, não deveríamos discriminar o atendimento em si frente ao psicótico.

Vários membros do grupo expressam não ter entendido a idéia.

I.- “Ai, gente, que horror. Eu não estou entendendo nada. Acho que todo mundo aqui é psicótico. Que horror! Não estou entendendo mais nada, viu?

$X .-$ "É diferente rótulo de diagnóstico, gente.

A. - “O atendimento é o modo como você vai utilizar o diagnóstico.”

Z.- "Acho que a grande coisa é você localizar a atenção no atendimento"

(...)

W. - Eu acho não querer rotular, também é uma forma de preconceito. Por que não falar o que é um psicótico, hein, gente?”

V.- "Não é uma definição, que você vá colocar o psicótico numa sala e pronto. Mas é como saber o que ele é, que tipo de trabalho é mais adequado e porque."

F.- “Queria falar uma coisa. Falar sobre psicose é uma questão básica. Falar de psicose e de inconsciente é super complicado, porque mexe com a gente.

I. “Mexe com a gente porque a gente está falando sobre o que é normal e o que não é normal. “

(...)

A. “Acho que é o grupo que está psicótico.” 
A experiência de caos se manifesta, apesar de haver uma tentativa de buscar mesmo que precariamente - formas para discriminar o que pode fazer referência a um conhecimento técnico e o que deste está a serviço da manutenção do preconceito e da exclusão. Novamente, podemos pensar na identificação do trabalhador com aqueles que são seu 'alvo de intervenção'.

É importante mencionar que o estado de confusão, no trecho acima citado, surge no momento em que o supervisor pergunta o que entendem por psicótico. Instala-se um nível de angústia relacionado, provavelmente, ao medo de se exporem enquanto profissionais e de se desqualificarem perante ao grupo. Ao tentarem definir o termo psicótico, buscam questões ligadas aos ideais antimanicomiais, as quais dizem respeito ao normal/patológico, ao preconceito, ao estigma.

Nesse sentido, buscam questionar o que é certo ou errado numa tentativa de desestigmatizar o rotulado de louco, mas ‘pecam' pelo inverso, homogeneizando categorias (ou papéis) totalmente heterogêneos. Enfim, é o estado de confusão generalizada na tentativa de lidar com o psicótico, 'humanamente’.

Num outro grupo, um profissional médico busca encontrar a lucidez no trato com a loucura, seguindo os princípios do modelo proposto:

“Me interessa pela demanda (psicóticos), até pela diretriz (do modelo); a prefeitura coloca-os como grupo a ser mais trabalhado, mas eu tenho pouca experiência. Tenho dificuldade, eu não estou conseguindo conter. Como psiquiatra você lê, você aprende, a questão da medicação; mas na prática não é assim; o contato com o psicótico é muito forte. Eu tenho que estar sendo mais lúcida do que ele. É muito interessante. A demanda é grande, e eu tenho vontade de estar aprendendo mas a insegurança é grande. ... eu fico deslocada, incomodada, nunca havia passado por isso.”

Nesta fala, o psiquiatra assume o papel de portador da razão e atribui ao psicótico, o da desrazão. O sentimento que parece daí emergir diz respeito ao medo de perder o controle, expresso pela razão/lucidez e ao mesmo tempo o desejo de ter uma relação de maior proximidade. Essa contradição aparece em vários momentos nos discursos de diferentes profissionais: busca-se um atendimento mais humano, mas o sentimento de impotência nessa ação persiste. Mais uma vez esse sentimento associa-se ao de inutilidade:

“... A contaminação da loucura do outro, no sentido de dó, de pena, é muito grande ... E porque daí bate a coisa do que eu posso fazer com ele ... essa coisa da inutilidade .”

A inutilidade do trabalho que se mistura à crença na inutilidade do doente mental permeia o cotidiano dos trabalhadores e parece estar assentada numa representação mais ampla 
de cunho social, oposta às propostas da luta antimanicomial. Podemos entendê-la como expressão da ideologia do normal e patológico, em que as diferenças que produzem a riqueza do cotidiano transformam-se em desigualdades ${ }^{198}$.

Uma das formas de categorizar os "diferentes" pode ser feita através da comparação entre o que se define como normal, patológico e produção dos comportamentos desviantes. Sobre este último, Velho ${ }^{199}$, ao discutir a noção de comportamento desviante, afirma que "tradicionalmente, o indivíduo desviante tem sido encarado a partir de uma perspectiva médica preocupada em distinguir o 'são’ do 'não são' ou do 'insano'. Assim, certas pessoas apresentariam características de comportamento 'anormais', sintomas ou expressão de desequilíbrios e doença. Tratar-se-ia, então, de diagnosticar o mal e tratá-lo."

A idéia de que o mal está localizado no indivíduo e de que o problema de desviantes diz respeito a uma patologia, tem ampla representação social, e como diz Velho é do nível do senso comum. Nesta representação o que se opõe à normalidade é patologia, é 'doença'. "A doença antes de ser definida como diversidade, é definida freqüentemente como anormalidade ou desvio, ou como inferioridade em relação à média da população."200

O ‘diferente’, sob o ponto de vista da psicanálise, está relacionado ao 'estranho', aquilo que freqüentemente assusta e incomoda. O 'estranho', segundo Freud, pode ser associado tanto ao que não é familiar, quanto ao que deveria ter permanecido secreto, mas veio à luz. Ou seja, faz parte da categoria do assustador, mas que se remete ao que já é conhecido e muito familiar. ${ }^{201}$

Podemos remeter esse diferente 'estranho' ao excluído do universo da normalidade socialmente construída. Assim, os 'conhecidos e desconhecidos' iriam se construindo a partir de relações que estivessem a serviço da manutenção da estrutura social vigente. Se hoje, por exemplo, a loucura é o desconhecido, isto se dá por ter sido banida como possibilidade de convivência cotidiana nas sociedades industriais, transformando-se em doença mental e apropriada pela 'ciência'.

198 Marilena Chaú́, apud Coordenadores do Projeto Hospital Aberto (Cadernos CEFOR, nº10, 1992), refere-se à conversão da diferença em desigualdade como um dos ângulos pelo qual se pode tomar a violência. "Entendemos por violência uma realização determinada das relações de força, tanto em termos de classes sociais quanto em termos interpessoais. Em lugar de tomarmos a violência como violação e transgressão de normas, regras e leis, preferimos considerá-la sob dois outros ângulos. Em primeiro lugar como conversão de uma diferença e de uma assimetria numa relação hierárquica de desigualdade com fins de dominação, de exploração e de opressão. Isto é, a conversão dos diferentes em desiguais e a desigualdade em relação entre superior e inferior. Em segundo lugar, como ação que trata um ser humano não como um sujeito, mas como uma coisa. Esta se caracteriza pela inércia, pela passividade e pelo silêncio, de modo que, quando a atividade e a fala de outrem são impedidas ou anuladas, há violência.” O sentido que estamos dando a essa conversão é exatamente esse da imposição autoritária, marcada por uma hierarquia dada aos pretensos detentores do 'saber'.

199 VELHO, G. (org.) Desvio e divergência: uma crítica da patologia social. Rio de Janeiro, Zahar, 1989, p.11.

${ }^{200}$ BERLINGUER, G. apud AMARAL, L. Espelho convexo: o corpo desviante no imaginário coletivo, pela voz da literatura infanto-juvenil. São Paulo, Tese (Doutorado), Instituto de Psicologia - USP, 1992.

${ }^{201}$ FARIA, M.C. Corpos estranhos, a imunologia entre Freud e Darwin. Ciência e Cultura, 1987. 
Se as exclusões vão se estabelecendo a partir de condições históricas e socialmente determinadas, é no âmbito das relações interpessoais que vão se cristalizando e se realimentando essa ideologia da normalidade.

Nesse sentido, consideramos que o 'diferente', nas relações intersubjetivas, sempre remeterá a um 'conhecido' que poderá ser atribuído a apenas uma parte dos envolvidos nesse processo e vivenciado por outros como inexistente. O conhecido que não se pode suportar remete-se à finitude, às limitações, à negação do que é idealizado (socialmente) como humano.

A sociabilidade estabelecida num grupo, como já apontamos, se dá sobre um fundo de indiferenciação, clivado e depositado nas estruturas institucionais. Uma nova experiência vivida pode estar relacionada tanto a algo totalmente desconhecido, quanto ao desconhecido que se inclui no interior daquilo que é conhecido.

Nesse sentido, Bleger afirma que "a sociedade tende a instalar uma clivagem entre o que se considera como sadio e como doente, como normal e como anormal. Assim, se estabelece uma clivagem muito profunda entre ela (a sociedade "sadia") e todos aqueles que, como os loucos, os delinqüentes e as prostitutas acabam produzindo desvios e doenças que, supõe-se, não têm nada a ver com a estrutura social. A sociedade se autodefende, não dos loucos, dos delinqüentes e das prostitutas, mas de sua própria loucura, de sua própria delinqüência, de sua própria prostituição; dessa maneira, ela os coloca fora de si mesma, ela os ignora e os trata como se lhe fossem estranhos e não lhe pertencessem. Isso se dá através de uma profunda clivagem. Essa segregação e essa clivagem são transmitidas pelos nossos instrumentos e pelos nossos conhecimentos." 202

Enfim, a circulação de idéias no âmbito social, certamente é determinante na constituição das subjetividades, ao mesmo tempo que imprime ao cotidiano de trabalho o medo do diferente, da indiscriminação, da loucura (e da identificação com ela) que se expressa na relação com o outro. Esse medo nos remete a uma problemática que é determinante na construção das novas práticas: a equipe multiprofissional.

\section{2 - A ‘equipe multiprofissional’: emblema da convivência dos diferentes}

O "novo" trato ao doente mental está relacionado com a convivência de olhares de vários profissionais, implicando diferentes tipos de "intervenção/relação" com "pacientes" diversos. A conjugação de todas estas diferenças coloca-se numa forma de trabalho, que

${ }^{202}$ BLEGER, J. Op. cit., 1991, p. 50. 
tem na equipe multiprofissional seu ideal, ora vivido como possível, ora como inalcançável. Nesse sentido, a equipe pode ser considerada emblemática no contexto das práticas antimanicomiais, por representar a possibilidade de síntese de diferentes aspectos na criação de um projeto comum.

Utilizando o referencial pichoniano, podemos afirmar que quanto maior a heterogeneidade da equipe ("cada membro traz para o grupo toda a bagagem de suas experiências e conhecimentos"), e maior a homogeneidade na tarefa proposta ("obtida pela somatória das informações" e assim "enriquecendo como parcialidade a cada um dos integrantes e, como totalidade, ao grupo”), maior o avanço em direção à criação de novas práticas. A atividade criativa da equipe pode ser considerada o aspecto mais significativo no alcance de seus objetivos. À medida que se enfrentam novas tarefas com novas técnicas, em que se adquire plasticidade na convivência coletiva, a equipe "opera com um pensamento criador, adquire funcionalidade. Então aparece como um fato objetivo que a tarefa em comum é de um rendimento superior.”203

A constituição da equipe multiprofissional carrega vários aspectos de mudança, entre eles, a estratégia de ruptura do modelo e do saber médico no contexto das práticas de saúde mental. Ela retira o lugar de hegemonia do psiquiatra e relativiza seu saber ao incluir outras categorias profissionais e seus respectivos campos teórico-técnicos no âmbito das práticas.

Desse modo, incluem-se ao campo de saúde mental, como constituição de saber e práticas inspiradas em princípios antimanicomiais, outros saberes e práticas que deverão ser reestruturados, revisados, superados em alguns aspectos para compor o referencial comum no qual a equipe se organiza.

Essa conjunção de diferenças implica um novo modo de atuar e vem permeada pelo medo do desconhecido nessa convivência. Podemos dizer que esse medo diz respeito aos diferentes referenciais teóricos e às práticas que cada categoria profissional carrega consigo e, ao mesmo tempo, às diferenças políticas e ideológicas a estes vinculados. A diversidade de referenciais reveste o cotidiano de trabalho e, na busca de ajuste, carrega a desvalorização de ‘saberes' específicos que pertencem a cada profissional. Dessa forma, ameaçam sua própria identidade profissional.

\footnotetext{
“Eu queria entender melhor esse desafio dessa equipe multidisciplinar...”
}

\footnotetext{
${ }^{203}$ PICHON-RIVIÈRE, E. Op. cit., 1
} 
“Eu vejo como importa o fato de estar junto. Só que a minha opinião é que deveria acontecer no cotidiano .... A gente entende que deveriam ter fóruns periódicos ... defendendo a idéia de encontros mais focalizados em um forma específica...”

O 'não saber' diante do novo trato à loucura na implantação das práticas substitutivas expressa-se no âmbito da equipe, diante do desafio em desenvolver o trabalho coletivamente.

B: “... Às vezes você quer dividir o não saber ... uma coisa que eu acho que falta é o suporte da equipe...”

G: “... mas a gente olha muito para o próprio umbigo...

...

I. “... a gente se sente como se não tivesse fazendo nada.”

Abaixo outra afirmação nesse sentido:

“Não foi coisa escolhida trabalhar com psicótico, porque tenho um caso parecido na família. Sou ousada, me meto, desafio. O que eu sinto é que a gente não consegue, me sinto constrangida no meio de tanta gente que analisa, estou tremendo por dentro. Me sinto estranha no ninho.”

Podemos destacar nesta fala, o constrangimento que emerge no primeiro encontro de um grupo de supervisão. O que haveria de tão constrangedor no trabalho em equipe? Outro profissional, ao final do mesmo encontro explicita:

“... como será que a equipe vai me ver ... dizer pros outros como é que eu vejo a loucura ... Eu tenho medo de falar para você do que eu acho da loucura. Como é que vão avaliar o meu trabalho..."

O medo de se expor e de não corresponder às expectativas referente ao papel profissional e, também, à respectiva implicação ideológica embutida no referencial teóricotécnico utilizado, está em questão. Contradições relacionadas ao saber $X$ não saber, associadas a padrões de normalidade $X$ anormalidade herdadas do modelo médico emergem nessa convivência grupal.

Nesse sentido, parece instalar-se uma 'normalidade' de ações dentro da instituição de saúde mental. Isto é, existiria um ‘jeito certo de ser’, de compreender o psicótico e de se colocar como equipe. A exposição denunciaria as diferenças e as dificuldades do 'não saber’ lidar com tais pacientes. Se existe um ‘jeito certo de ser’, um jeito que corresponderia à 
normalidade de ação, 'desviar-se’ (ou não se 'encaixar') dessa normalidade, tornaria tênue o limite entre profissional $X$ usuário: o trabalhador, do mesmo modo que seus 'pacientes', estaria agindo fora da normalidade, a qual ele desconhece, mas supõe que exista e imagina ser a esperada pela instituição.

Uma outra fala aponta que num grupo de supervisão constituído há mais tempo, No qual de certa forma há um conhecimento sobre as normas instituídas, a exposição pode ser menos persecutória:

"Quando um grupo é antigo, a gente se sente mais à vontade no trabalho, a gente tem mais base para ousar; agora, quando é novo, existe muito medo nisso. ... Há uma insegurança no novo, no montar o grupo, na mudança, instabilidade da equipe."

A busca da construção de laços de coesão no trabalho em equipe faz com que a insegurança diante do novo possa ser revelada. Essa explicitação permite ao grupo conhecer os fantasmas que impedem a consecução do trabalho e, deste modo, o desenvolvimento da grande tarefa que lhes foi imbuída dar-se-á de forma menos angustiante.

Nessa tarefa de referencial teórico incerto e questionador, cujo objetivo é criar/recriar (concepções, técnicas e a própria inserção institucional), o processo de trabalho, como já apontamos, vai sendo marcado por diversos conflitos. Entre estes, alguns dizem respeito à perda/busca de identidade, agora remetida à própria equipe de trabalho. Constituir-se como equipe também se torna uma árdua tarefa: haverá predominância de um saber sobre outro? Será possível romper/superar a hegemonia do saber médico? Será possível romper com formas normatizadoras e estigmatizantes em lidar com os excluídos, com a diferença do cliente e da própria equipe?

Diante dos conflitos emergentes a partir de tantas diferenças, uma das formas de contemporizá-los se evidenciaria pela tentativa de homogeneização ou pela própria eliminação das diferenças, principalmente daquelas que dizem respeito à formação profissional, contrariamente ao princípio antimanicomial. Ou se abandonam as próprias concepções, abrindose mão da especificidade em função do grupo; ou se busca a prevalência de um determinado ponto de vista, o que culmina na incomunicabilidade e impossibilidade de convivência num projeto comum.

No primeiro caso, ganha-se um elo comum mas, simultaneamente, abre-se mão daquilo que é específico de cada profissional, ou seja, da sua própria identidade. ${ }^{204}$ No segundo

\footnotetext{
${ }^{204}$ Essa forma de lidar com a diferença parece ser mais comum nos novos equipamentos, HD e CECCO, já que estes estão em fase de constituição e é necessário uma sintonia entre os profissionais para se justificar os objetivos propostos. Podemos afirmar que neste contexto há uma indefinição que diz respeito tanto aos papéis dos profissionais dentro da equipe multiprofissional, como também do próprio equipamento dentro da rede de serviços proposta no novo modelo.
} 
caso, instala-se a incomunicabilidade entre profissionais a partir da tentativa de se sobrepor a um ponto de vista, ou determinado tipo de conhecimento teórico ou técnico sobre os demais. Isto acontece mesmo quando existem dúvidas quanto à validade da utilização deste conhecimento adquirido como parte da formação universitária. ${ }^{205}$ As categorias profissionais entram em choque.

“Sabe o que aparece muito (no trabalho) em fono? Aquela família super legal que você cavoca, cavoca, cavoca e não acha nada. E a gente que trabalha com pessoal, com psicólogo, eles começam a achar pelo em ovo. Às vezes é outra coisa (...) Às vezes eu faço todos os exercícios que eu aprendi na faculdade. A criança faz todas as atividades. Tá ótimo, tá tudo muito. Só que continua com a mesma cara (imita um ortodôntico). Mas às vezes falta alguma coisa, me dá uma aflição de ver as coisas não andarem. (...) Eu acho o seguinte: eu acho que fono tem que conseguir fazer alguma coisa, o que for. Não que não tenha problemas psíquicos na jogada, mas que a gente possa trabalhar enquanto fono. (...) Tem uma formação que é a tradicional que é contrária a tudo isto."

Desta fala podemos destacar o questionamento sobre os saberes produzidos em outras áreas e, junto com este, a constatação de que o próprio conhecimento específico, muitas vezes se mostra insuficiente para o alcance dos objetivos propostos. Assim, podemos também levantar questões referentes ao lugar que cada profissional ocupa nessa equipe.

Verificamos nas falas dos trabalhadores, algumas queixas presentes em relação ao psicólogo. Em alguns casos, este profissional é acusado de se deixar perder numa incursão pelo mundo psíquico, distanciando-se das determinações que estão para além dos fatores emocionais. Desse modo, torna-se freqüente a expressão de um certo desprezo em relação ao conhecimento específico dessa área 'psi', por parte das outras categorias profissionais.

O conjunto de conhecimentos teórico-técnicos produzidos no campo da Psicologia não permitem uma verificação 'objetiva' dos efeitos da prática sobre o âmbito psíquico (seu alvo de ação). Assim, a ação desse profissional é associada a algo misterioso e, até mesmo, mágico. No contexto de construção de novas práticas em saúde mental, no qual não há um terreno teórico seguro, o psicólogo torna-se alvo de depositação dessas incertezas e do 'não saber' vivido pela equipe.

Por outro lado, o fato de não serem objetivamente compreensíveis os efeitos dessa prática, permite também a atribuição de um 'saber' que apenas ele domina. Nesse caso, ele ocupa um lugar de poder frente à equipe.

\footnotetext{
${ }^{205}$ Nos equipamentos já constituídos e com objetivos mais definidos, como as UBSs, a incomunicabilidade parece prevalecer. Isto porque tornou-se possível a cada profissional desenvolver seu trabalho independentemente dos demais componentes da equipe, e desta forma indo num sentido inverso ao proposto no modelo.
} 
O psicólogo tem representado na relação entre profissionais da equipe de saúde, aquele que disputa com o médico o lugar de hegemonia. A própria prevalência do dispositivo de supervisão clínica e institucional, como mecanismo de formação, imprime ao trabalho ações específicas dessa área.

Contudo, o psiquiatra continua exercendo seu poder no trabalho de equipe, quer ele queira ou não.

B. “... eu não sei direito de quem eu tenho que dar conta...”

A: “... a gente não tem aqui esse estrategista....”

C:“... acaba sendo o psiquiatra... mudou muito pouco com a mini equipe...”

Outras falas:

"Conseguimos controlar esses casos. Se não houver um psiquiatra que não souber lidar com isso, o grupo não agüenta. .. É preciso que o grupo esteja integrado, com um psiquiatra que medique o indivíduo para que ele possa ser encaminhado para a terapia ... É necessário uma interferência psiquiátrica efetiva para atenuar a dor mental. A equipe de saúde mental tem que discutir cada caso, ver seus ângulos, suas possibilidades, para depois encaminhá-la... Eu fico surpreendido com o fato de que as equipes são completas, mas não são traçados objetivos, é necessário montar projetos, planos, articulação da equipe.”

“...o modelo médico me salva de vez em quando ..”

A categoria médica é alvo de duras críticas feitas pelos demais profissionais, mas, ao mesmo tempo, parece apresentar-se como ‘dona’ de algumas certezas, as quais, muitas vezes, chegam a ser estruturantes para a própria equipe mesmo dentro da lógica antimanicomial. A idéia de que o modelo médico ‘salva' de vez em quando não é válida apenas para os psiquiatras, como já pudemos perceber, mas também para outros profissionais.

O psiquiatra ao fazer uso de medicamentos, utiliza um instrumento concreto, palpável e que produz efeitos imediatos principalmente para pacientes em crise. Se, por um lado, a utilização generalizada desse recurso gerou condutas distorcidas no tratamento psiquiátrico, substituindo qualquer outro tipo de recurso e contribuindo para a cronicidade de muitos desses pacientes, por outro, é inegável a importância que assume ao permitir a diminuição da ansiedade de pacientes impossibilitados da convivência social, permitindo inclusive a intervenção técnica de outros profissionais no tratamento (por exemplo, a realização de psicoterapias, oficinas etc.).

Assim, ao mesmo tempo em que se busca romper com a hegemonia do saber médico, a prática daí advinda tem se mostrado como um dos elementos estruturantes na 
construção do novo modelo. Trata-se, mais uma vez, de se redefinir os limites dessa atuação, conservando-se parte dos aspectos que têm se mostrado necessários e superando sua tendência normatizadora e excludente.

Em vários momentos no cotidiano do trabalho, a especificidade médica reacende posturas mais clássicas que demarcam a diferença em ser médico e não outro profissional. Vale mencionar que mesmo na forma de inserção nos grupos de supervisão essa diferenciação está colocada.

A participação dos médicos nesses grupos tem sido pequena, às vezes nula em termos numéricos. Entretanto, pudemos perceber que, quando estão presentes, a qualidade da participação é diferenciada: os mais críticos e confiantes na nova proposta chegam, algumas vezes, a ocupar mais espaço (nos grupos de supervisão) do que outros profissionais; na busca de legitimação, os mais tradicionais, por sua vez, colocam-se numa postura de espectadores, não participam de todo o processo e chegam a explicitar certa depreciação frente às discussões estabelecidas no grupo. ${ }^{206}$

Se, em alguns casos, a forma de contemporizar os conflitos emergentes diante do medo da perda/busca de identidade na equipe se dá pela tentativa de prevalência de um dos campos de conhecimento (geralmente o médico); em outros, como assinalamos acima, abre-se mão da especificidade profissional em função da constituição da equipe.

O que se verifica com freqüência é que essa tentativa de homogeneização das diferenças dentro da equipe se expressa pela utilização de técnicas alternativas não específicas ou circunscritas ao trato à doença mental.

"Não se trabalha sem ser em equipe, principalmente com psicótico. Eu já tenho feito alguma coisa ... Tenho formação em trabalho corporal. Eu acompanho algumas coisas aqui no HD, como o tai chi"

Tem sido freqüente a busca de técnicas entendidas como 'alternativas, ${ }^{207}$, destacando-se aquelas que privilegiam o trabalho corporal, principalmente entre os 'novos'

${ }^{206}$ Num texto escrito por supervisores do Instituto Sedes Sapientiae intitulado "Sobre um Projeto de Formação na Rede Pública”, que relata e levanta algumas indagações sobre a experiência de formação em saúde mental aos trabalhadores da Secretaria Estadual da Saúde, é constatado que são poucos os médicos que comparecem aos espaços de supervisão criados em algumas regiões de São Paulo. Entendem que isso não acontece por acaso, mas que o modelo médico é dominante na rede, o que faz com que os outros profissionais percebam seu saber como desvalorizado. Levantam a seguinte questão: "Os profissionais respondem com interesse à proposta de formação. Mas, trata-se tão somente de um desejo de formação ou, sentindo sua ação como pouco resolutiva (segundo um modelo médico que dá, cura, salva), buscam um saber eficaz que também se traduz em pedidos como cursos rápidos, de psicoterapia de grupo, psicoterapia breve etc., que possam vir a ser administrados como "a vacina”, "o leite”, “o remédio”?...”

${ }^{207}$ Vários são os tipos de técnicas alternativas que se incluem nos serviços de saúde mental. Muitas delas não são oriundas das práticas 'psi', por exemplo, tai-chi-chuan, expressão corporal, atividades artísticas, como teatro, música etc. No âmbito específico das práticas 'psi', podemos considerar principalmente aquelas que se mostraram alternativas à abordagem psicanalítica. Num contexto mais amplo, segundo Coimbra, 1992, as práticas de psicodrama e posteriormente as relacionadas ao movimento do potencial humano são as primeiras a 
equipamentos voltados ao atendimento a psicóticos, a partir de uma abordagem multiprofissional.

A utilização de técnicas corporais no atendimento aos usuários dos serviços de saúde mental tem produzido efeitos positivos (eles passam a se sentir melhor com esse tipo de trabalho), embora não se tenha conhecimento sobre o tipo de mudança que ocorre no 'campo mental'.

Este tipo de ação permite ao trabalhador atuar num campo delimitado e mais conhecido do que o 'mental': desloca-se a atenção do corpo representado no mundo psíquico para ação sobre um corpo concreto. Desse modo, conservam-se aspectos específicos do modelo médico (o corpo), cujo ‘domínio’ proporciona certa segurança e concertade na ação, e são 'superados’ outros considerados manicomiais.

Além disso, a realização desse tipo de trabalho aparentemente não exige dos profissionais um aprofundamento teórico sobre a utilização das técnicas. Desse modo, pode ser utilizado indiscriminadamente por todas as categorias profissionais. No âmbito institucional, tem sido enfatizada a realização de oficinas ou espaços de convivência nos novos serviços, priorizando recursos não convencionais no trato à doença mental.

Apesar da relevância da utilização de técnicas alternativas, podemos entendê-las também como uma das formas de encobrir ansiedades que surgem a partir da necessidade de desenvolver o trabalho em ações conjuntas com outros profissionais. Ao utilizá-las, muitas vezes, abre-se mão da especificidade e, conseqüentemente, da própria identidade.

Quando um profissional como o psicólogo, por exemplo, passa a fazer tai-chichuan, expressão corporal, atividades artísticas etc., enfatizam-se aspectos que não dizem respeito a sua especificidade profissional. Nessa situação o ‘não saber’ seria permitido.

No entanto, deixar de lado aquilo que é próprio de cada profissional, exercendose tarefas que não se domina ou para a qual não se tem formação, faz com que surja, mais uma vez, o sentimento de inutilidade do trabalho e a dúvida sobre o que realmente está sendo criado. Neste contexto, geralmente as equipes se relacionam muito bem, porém as diferenças não podem aparecer.

Podemos dizer que o ideal da convivência da diferença se frusta na constituição da equipe multiprofissional. A exclusão se dá entre os próprios profissionais, seja não

\footnotetext{
se colocarem como 'alternativas' ao mercado monopolizado pela psicanálise, principalmente partir do início dos anos 70. Tanto o Movimento que tem como finalidade descobrir os 'meios de melhorar o potencial humano’, utilizando-se de um conjunto de técnicas grupais, corporais, psicodramáticas, de massagens, bioenergéticas e da filosofia oriental, e o movimento relacionado ao psicodrama rechaçam a psicanálise e as psicoterapias que se baseiam exclusivamente na fala, fazem a crítica ao especialismo e enfatizam o enfoque grupalista como forma de atuação. Estas técnicas passam a ser difundidas amplamente, a partir da década de 70, até mesmo pela facilidade de acesso à formação, ao contrário da psicanálise. Esses movimentos se inserem ao movimento de contracultura da mesma forma que o movimento de antipsiquiatria a partir de 1968.
} 
valorizando o conhecimento específico de seus pares, seja excluindo aquilo que pode ser específico de sua própria categoria.

Desse modo, mesmo desenvolvendo o trabalho em equipe, muitas vezes o trabalhador expressa um sentimento de solidão. Por não se saber até onde vão os limites de sua atuação, instala-se uma situação de incomunicabilidade que se expressa pelo sentimento ambivalente de invadir/ser invadido, configurando-se uma relação em que é difícil ouvir o que o outro tem a dizer. O trabalho em equipe cai no esvaziamento:

C: " A reunião de discussão de caso tá capenga."

I: "Mesmo quando a gente tem.... Quem fala só é escutado, mas não recebe nada de volta...”

M: "Eu que sou uma pessoa que falo muito me sinto invadindo o caso do outro"

I: “... Dar a palavra a cada um... Acaba acontecendo isso: dois falam ... e a maioria entra mudo e sai calado ... Não tem nenhum 'feedback' ... Quem entrou para falar do caso sai tão vazio, tão solitário ... Nós nem sabemos quem somos..

B: “... Aquela sensação de que não deu para conversar ... Tem que ter um horário em comum e tem que ser contemplado o individual ... A gente vai ter que achar um termo.

Além do sentimento de solidão, vive-se também, contraditoriamente, a raiva pela de falta de autonomia, de independência em relação a suas próprias ações. Num trabalho coletivo as decisões, com freqüência, não podem ser tomadas pelo profissional independentemente da opinião da equipe.

M: "É evidente que eu acompanho mais os pacientes que eu acompanho ${ }^{208}$... A decisão de alta não depende de mim ... Eu acho que sobra uma puta duma raiva e desespero do que vai ser feito do paciente."

Até aqui falamos das diferenças/divergências postas entre os trabalhadores da equipe de saúde mental. Ao considerarmos a 'equipe multiprofissional' como emblemática e ao ampliarmos nosso foco de atenção para o âmbito institucional, podemos perceber a emergência de outros tipos de conflitos que se expressam a partir da relação estabelecida entre técnicos $X$ não técnicos, ou seja, a relação estabelecida entre equipe de saúde mental e demais trabalhadores que não possuem formação universitária (auxiliares de enfermagem, auxiliares administrativos, porteiros contínuos etc.). Se no âmbito da equipe de saúde mental instala-se

${ }^{208}$ Nos Hospitais Dia, apesar dos profissionais atuarem em vários casos enquanto equipe, cada profissional fica responsável por um determinado $\mathrm{n}^{\circ}$ de pacientes. 
uma hierarquia informal, tendo destaque a figura do psiquiatra, no âmbito institucional, outro tipo de hierarquia se faz presente:



I - "Em alguns casos são. Eles defendem que eles moram ali do lado do equipamento ... ( a dúvida em poder ser atendido ou não) é uma coisa que fica mais para saúde mental . Por estas questões todas: de ser um local de trabalho, um local de atendimento ... é confuso.”

Os conflitos provenientes das contradições do novo modelo, emergentes na convivência da equipe multiprofissional, nesse caso, deslocam-se para o âmbito da instituição (unidade de saúde). Isto quer dizer que se no âmbito da equipe as divergências são impeditivas de sua constituição, no âmbito institucional tais categorias se unem, e passam a se representar como equipe frente a outros tipos diferenças/divergências que se expressam pela cisão técnicos/não técnicos.

Uma das formas de manifestação desta cisão se dá por processos de identificação dos não-técnicos com a população que utiliza os serviços de saúde. Freqüentemente os não técnicos identificam-se e são identificados com esses usuários.

A identificação se dá principalmente em função da similaridade de 'representações' que circulam sobre a condição de vida entre eles. Parcela significativa dos nãotécnicos moram próximos aos locais de trabalho, conhecem os usuários dos serviços (às vezes são seus vizinhos) e em alguns casos têm condições sócio-econômicas muito parecidas. É comum eles ou seus familiares utilizarem os serviços das unidades em que trabalham (principalmente quando são unidades de saúde geral).

Desse modo, muitas vezes, os técnicos não fazem diferença entre eles e os usuários. Os 'não-técnicos', por sua vez, ao mesmo tempo em que procuram se diferenciar dos usuários (a partir do atendimento que dão a estes, muitas vezes maltratando-os), com eles se identificam, ocupando o lugar daquele que deve ser tratado e que possa usufruir do conhecimento dos profissionais especializados (pedem ajuda para seus próprios problemas).

Essa indefinição de papéis traz à tona, mais uma vez, a expressão de sentimentos dos profissionais da equipe de saúde mental, os quais se alternam entre onipotência e impotência e geram um estado de confusão e indiscriminação.

I. "Em janeiro eu estava grávida ...Entrou uma funcionária (na sala e perguntou) 'posso fechar a porta?' Entrou na sala e me contou que estava grávida de um mês.(...) (Perguntou) se 
devia continuar tomando Diazepan ou não. Começou a falar de outras coisas (sobre) a vida dela: aborto aos 16 anos, muito medo de perder esse bebê. Sugeri procurar psicoterapia, retomar com a mesma pessoa que a tratou antes.(...) Até que ponto a gente intervém, ou não faz nada ... até que ponto a gente como equipe vê um comportamento muito esquisito e não faz nada, entende? (...) (Ela) é alguém que talvez não tenha nenhuma noção do que eu estou pensando ... por isso não posso considerar colega ... aquela pessoa está me perguntando não porque sou I., mas porque sou psicóloga.”

M. “É difícil separar. Você é I psicóloga.

(confusão, comentários, conversas paralelas)

$V$ “... ela pode estar como pessoa, mas eu reagiria do mesmo jeito. ... É claro que ela está te procurando como psicóloga. Ela não tem essa discriminação ... esse jargão ... quando a pessoa não sabe, ela é mais ingênua, até mais indiscriminada no jeito de procurar."

Outras falas:

“... se um funcionário entra em fase maníaca, nós vamos ficar de olhos fechados? ... Tem uma pessoa que está com um problema, a gente não vai perguntar como ela está? A questão é. até onde pode estar intervindo, você está em que papel? Até que ponto a equipe de Saúde Mental intervém ... ponto que é muito complicado.

“Às vezes a gente percebe coisas que a outra colega não percebe ... O que a gente faz com isso que a gente percebe?

Frente aos 'não técnicos', ‘ingênuos', ‘sem formação', 'pobres' pode ser considerado possível aos técnicos ocupar lugar de saber, de autoridade e poder. A probabilidade de 'enlouquecer', por exemplo, está neles depositada. Não se cogita essa mesma possibilidade, no sentido estrito do termo, dirigida aos técnicos. O 'saber' representaria a 'fórmula' contra a loucura: aos portadores do saber, a razão; aos desprovidos de conhecimento, a loucura. Desse modo, a posse do conhecimento permitiria a separação, a diferenciação entre trabalhadores de saúde mental e seus pacientes.

Acrescentaríamos a isto que o sentimento de onipotência do trabalhador parece estar determinado também por outro tipo de representação corrente, que diz respeito às formas de atuação em saúde mental. Lembremos que as concepções difundidas e que muito influenciaram a constituição dos serviços, embora extremamente criticadas pelas correntes de reforma psiquiátrica com ênfase na desinstitucionalização e que fundamenta o movimento antimanicomial, foram herdadas da psicologia comunitária americana. Segundo esta, cabe ao profissional se inserir em todas as frentes possíveis, principalmente na comunidade, identificando seus problemas e sobre eles atuando. Ser trabalhador em saúde mental é ser 
‘militante/humanitário’ e, assim, cuidar dos não-técnicos passa também a ser uma questão posta pelo próprio modelo preventivista.

Essa concepção, de um lado, choca-se com um outro tipo de representação corrente influenciada principalmente pela psicanálise.

Atender ou não atender o colega de trabalho parece estar relacionado com a função e/ou o papel que o profissional de saúde mental deve assumir: intervir na comunidade ou fechar as portas e garantir a privacidade. Intervir na comunidade estaria relacionado com a representação de que todos os espaços devem ser trabalhados pelos profissionais. Fechar as portas relaciona-se a manter um distanciamento em relação àqueles com os quais se convive diariamente.

Tal contradição, que pode ser remetida a questões que dizem respeito ao sentido do terapêutico $X$ não terapêutico, invade o espaço de trabalho confundindo e misturando aquilo que diz respeito ao profissional e à vida privada e produzindo separações forçadas (por exemplo, separar ser 'pessoa' do ser 'profissional') que de certa forma acentuam a sensação de insegurança e impotência no trabalho. Atos de solidariedade confundem-se com ações de saúde mental. Ouvir o problema do colega de trabalho ou emitir algumas opiniões torna-se um tabu, pois muitas vezes essa ação é confundida com atendimento.

"Pra mim está claro que não era para atender ... eu ouviria, e daí dava um encaminhamento ... Escutar o que ela tem a dizer é um atendimento.”

“Eu ouviria o que a pessoa tem para falar mas eu não continuaria, encaminharia para um posto mais próximo.”

“ Eu acho que a gente é o produto final de um monte de coisas ... Se é médico é médico ... Não adianta, na pescaria, dizer que não é médico. Se machucou o dedo a gente vai ajudar ... Eu, enquanto pessoa, acho que a consciência minha ficaria mal ... Se é meu amigo eu tenho algo a falar, mas eu tenho que limitar esta atuação ... Mas há muitos momentos em que mescla tudo.”

Mas, o sentimento de onipotência, referente à possibilidade (ou não) de intervir na vida dos colegas de trabalho logo se dissipa. A identificação dos não técnicos com usuários, ou a busca de ajuda junto aos técnicos expressa um lado da inserção desses trabalhadores na instituição. A tentativa de se diferenciarem dos usuários e a desqualificação do trabalho dos profissionais de nível universitário representam outro lado da mesma moeda. Desse modo, eles muitas vezes se 'rebelam'. Mais uma vez o sentimento de impotência prepondera na equipe de saúde mental. 
R. - "Ontem eu fiz isso de segurar o choro e eu me arrependi. A gente está começando um relaxamento lá no posto, e é na sala que todo mundo usa e tem um monte de 'tralha', botam tudo que é coisa lá. (...) Eu lá do fundo do posto pedi para o(porteiro-)contínuo dar um jeito. Já tinha passado da uma hora da tarde, a gente estava atrasado. E aí eu perguntei: 'V., e agora o que eu faço com aqueles papéis?' Ele disse: 'Ah, acabou o meu horário de trabalho.' E aí antes de entrar no grupo eu falei com a chefia. Eu saquei que eu não consigo lidar com isso, com essa barra de grosseria, porque eu tento tratar super decentemente as pessoas, o que não foi o caso dele. Quem veio depois foram outros, os contínuos da tarde. Ele não veio, ficou lá, sentado. Aí eu quase chorei, fiquei com um nó na garganta, fiz um escândalo lá atrás. ... Mas não tenho vontade de resolver. Fico pensando se vale a pena me desgastar, fiquei com muita, muita raiva. É uma coisa de me segurar para não perder o controle, mas eu tinha que retomar o controle pra trabalhar. “

M. - “É, mas eu acho que não é choro que quer sair. Você falou que ficou com um nó na garganta, acho que não é choro que quer sair, é raiva mesmo.

Z. - "É todo um sistema que funciona tanto assim. Não dá pra consertar isso. Tem que zerar tudo - (risos no grupo) - não tem ideologia, não tem partido que conserte isso. A pessoa não percebe o quanto isso prejudica ela própria.

Supervisor - "Será que não dá para dar um jeito de ir conversando com um, com outro."

Z. "Não dá, a estrutura é grande demais."

Supervisor - “Não, não pensar em termos de estrutura, porque aí é ideal demais. Mas pensar no pequeno.”

R. - “Eu acho que é super desgastante. E pra mim é super fácil brigar. Eu prefiro conversar. E eu não sei se só conversar adianta. E quando eu brigo, eu saio arrasada. (...) ... pra mim a raiva passa pela agressão. Eu me sinto agredindo o outro, eu não me sinto bem com isso.”

Supervisor - “Ah, mas você foi agredida também.”

A. - "Eu acho que a contenção da agressividade acaba virando violência."

S. - “Gozado, eu trabalhei numa clínica particular. Pra fazer exame era terrível, por causa do trabalho que todo mundo fazia, a cozinheira, o médico, o ginecologista. Eu acho que é uma coisa cultural, não é só do funcionário público. É coisa do grupo mesmo.”

Na construção de equipe, como já dissemos, são vários os conflitos e indiscriminações vividos que dizem respeito ao estar com o 'outro' como possibilidade de construção de uma proposta coletiva. São diferenças/divergências entre categorias profissionais, entre equipe de saúde mental/equipe da instituição, entre técnicos/não técnicos. Mas, se o diálogo acima aponta a impotência e indiscriminação ao justificar o truncamento de comunicação como responsabilidade do âmbito da macro-estrutura, ele traz também novos elementos que podem possibilitar certo discernimento. O fato de se reconhecer que em outras instituições, não somente as públicas, às quais eles pertencem, trazem esse tipo de dificuldade, 
retorna um pouco da responsabilidade para o próprio grupo e a possibilidade de se verem como sujeitos do processo.

Pudemos perceber que algumas das contradições reveladas a partir dos sentimentos de impotência/onipotência na implantação da rede substitutiva inspirada nos princípios antimanicomiais - saber X não saber, loucura/doença mental X saúde mental, normal $\mathrm{X}$ anormal/patológico, modelo médico $\mathrm{X}$ modelo não médico, terapêutico $\mathrm{X}$ não terapêutico - , e a conseqüente perda de limites, geradora de indiscriminações entre trabalhadores $\mathrm{X}$ usuários, técnicos $\mathrm{X}$ não técnicos, neurose $\mathrm{X}$ psicose, eficiência $\mathrm{X}$ ineficiência de técnicas, pessoal $\mathrm{X}$ profissional dizem respeito tanto ao trabalhador no lidar com a questão de uma nova concepção de saúde mental, quanto à sua correlata exigência: a construção da equipe no âmbito institucional.

Considerando essas mesmas contradições, abordaremos a seguir questões relativas à formação do trabalhador em saúde mental, alvo de sua própria preocupação, bem como das instâncias administrativas e definidoras das políticas públicas de saúde.

\section{3 - Formação dos trabalhadores em saúde mental:}

\section{a supervisão clínica-institucional como dispositivo}

O tema 'formação' tem tido lugar de destaque nos debates voltados para a definição de políticas públicas de saúde e reestruturação do serviços de saúde mental. As propostas de reorganização do sistema de atenção, em busca do modelo de um Sistema Único de Saúde (SUS), são acompanhadas de discussões sistemáticas no sentido de se definir diretrizes para a formulação de uma política de recursos humanos de âmbito nacional. "Não cabe nessa nova organização, uma qualificação técnica centrada em conhecimentos tão somente biológicos, fragmentada em campos profissionais, fazendo com que cada profissional domine apenas uma parcela do conhecimento necessário à atenção à saúde. Essa organização deve se dar em bases coletivas, em decorrência da integração entre as várias categorias profissionais e do próprio objeto de trabalho". ${ }^{209}$

${ }^{209}$ MOTTA, R.M.M. Formação em serviço para profissionais de sáude: um programa em questão. São Paulo, Dissertação (Mestrado), PUC-SP, 1994, p.1. 
Desse modo, a formação de trabalhadores em saúde apresenta-se como tema complexo por estar voltada para a organização de um trabalho coletivo, fundamentado em diferentes abordagens. No caso específico das práticas em saúde mental somam-se outros aspectos que aprofundam essa complexidade.

Por ser instrumento de trabalho nessa área a própria subjetividade dos trabalhadores e as relações estabelecidas entre eles e também com seus 'pacientes', aspectos intersubjetivos incluem-se como problemática nos projetos de formação. Isto não quer dizer que tais questões sejam exclusivas do trabalho em saúde mental, mas que neste caso, elas deverão ser constantemente problematizadas para efetivação das ações.

Além da importância que o tema 'formação' assume na definição de políticas de saúde mental, no âmbito das práticas passa a ser alvo de mobilização dos trabalhadores. Esta se expressa, principalmente, por reivindicações ao poder público da definição de uma política e da instalação de projetos de formação.

Tais solicitações se justificam quando nos deparamos com o triste quadro da realidade educacional brasileira: o ensino básico fundamental de péssima qualidade, a grande proliferação de cursos universitários, muitos deles sem o controle necessário sobre a qualidade de ensino que oferecem etc.

Os cursos universitários, no geral são organizados em torno de um currículo mínimo de disciplinas. Os critérios para composição dessas disciplinas e a organização dos cursos passam, muitas vezes, por uma lógica que segue tendências voltada para a venda do produto 'graduação universitária'. Esta tendência se acentua principalmente nas universidades privadas.

No que diz respeito à formação profissional nas áreas médicas e 'psi, há uma procura por parte dos alunos por cursos que os capacite a desempenhar funções valorizadas socialmente e que carreguem consigo a possibilidade de consolidarem o ideal de autonomia no trabalho, característico do pensamento liberal. Desse modo, haverá uma ênfase na prática clínica privada na formação universitária e, conseqüentemente, pouco espaço para o aprofundamento de referenciais teórico-técnicos voltados para o fortalecimento de instituições públicas que buscam romper com idéias e práticas hegemônicas.

As universidades públicas, por sua vez, não se orientam por tal lógica e, desta forma, têm obtido avanços na produção crítica de novos conhecimentos e na formação, transcendendo os limites desta, acima referidos.

Se há avanços em alguns âmbitos universitários, estes não vêm no mesmo ritmo das práticas que vêm sendo implantadas. O distanciamento entre universidade e instituições públicas prestadoras de serviço se manifesta num descompasso entre teoria e prática na construção de novos modelos. 
Assim, muitos profissionais - mesmo os egressos de faculdades reconhecidas nacionalmente, destacando-se as públicas - saem de seus cursos revelando não se sentirem capazes de desempenhar sua nova função, por não terem se apropriado de alguma 'técnica' ou por esta não se adequar à realidade na qual vão atuar. Neste caso, o domínio ou a falta de um referencial por parte do trabalhador entra em contradição com sua ação.

Um sentimento de 'fracasso' muitas vezes emerge e passa a ser explicado por limitações de ordem pessoal, ou das condições dos serviços que não permitem a aplicação 'adequada' da técnica, tal como foi aprendida. Cria-se a ilusão de que se a técnica fosse bem aplicada ou, um conhecimento bem assimilado, o desempenho profissional a partir da capacidade individual seria satisfatório.

Podemos compreender tal percepção como mais um dos aspectos que se somam à indiscriminação no contexto de trabalho, agora relacionado às limitações da formação. Tal indiscriminação, além de impedir a percepção de que conhecimentos podem ser produzidos ou ressignificados na prática coletiva, geram sentimentos de 'baixa auto-estima', levando à desvalorização do serviço público e valorização da iniciativa privada e liberal.

Desse modo, a reivindicação dos trabalhadores por uma política de formação na área de saúde mental, destacando-se a supervisão clínica e/ou institucional, como dispositivo privilegiado, representa uma das formas de contornar tais problemas.

Consideramos que a grande ênfase em se eleger a supervisão como dispositivo de formação diz respeito, em parte, à complexidade inerente ao trabalho em saúde mental, que carrega consigo aspectos intersubjetivos para a realização da tarefa. Verificamos que tal dispositivo passa a ser depositário de várias expectativas, como se pudesse conjugar e responder a grande parte de necessidades geradas na implantação de rede substitutiva. Como poderemos ver a seguir, muitas das expectativas não dizem respeito à formação. Agrupamos parte delas em quatro tipos, de acordo com os objetivos perseguidos pelos trabalhadores.

1. Suprir deficiências da formação universitária e incluir questões relacionadas ao novo trato à doença mental (novo espaço de formação).

"Tenho grandes expectativas sobre supervisão institucional. Tenho deficiência de formação de atender as crianças. Tanto eu quanto a outra psiquiatra."

"Eu não conheço praticamente nada de abordagem corporal. E a expectativa é de aprender mesmo."

"A minha expectativa é mais teórica. Conversar sobre o que é o doente mental. Definição de prática de trabalho.” 
“... como lidar com um doente mental. Não numa clínica específica, mas o geral de como tratar o doente nas diversas situações."

Apesar de parte dos pedidos estarem voltados à discussão relacionada a uma nova abordagem sobre a doença mental, preponderam expectativas relacionadas à complementação de formação. Em alguns casos, estas são reafirmadas pela própria expectativa do supervisor:

“Aqui eu tenho uma preocupação dupla: a primeira se refere ao que pode ser feito pelo paciente no hospital; a outra é sobre a formação de vocês, que as faculdades não dão conta. Aqui vocês terão auxílio de quem já vem pensando muito nessas questões.”

Se, por um lado, identificamos certa precariedade da formação universitária dos trabalhadores, por outro, no contexto de implantação de novas práticas inseridas nos serviços públicos de saúde, muito está por ser (re)construído, como já apontamos anteriormente. Sendo assim, grande parte das ações voltadas para tais práticas não podem ser ensinadas num processo 'formal' de aprendizagem desenvolvido nos cursos universitários, enquanto não houver um menor distanciamento entre Universidade X Serviços, entre teoria e prática. O trânsito entre esses âmbitos e seus espaços de produção e, conseqüentemente, a ressignificação de ambos se tornam indispensáveis para o avanço dos fundamentos e práticas antimanicomiais.

Ao nos depararmos com expectativas de complementação de formação, seja por parte dos supervisores, seja pelos trabalhadores/supervisionandos, encontramo-nos novamente com questões que dizem respeito à 'saber $X$ não saber'. Não se atualizaria nesse encontro (supervisor e trabalhadores) a crença sobre a existência de um saber constituído/verdadeiro no contexto de implantação de novas práticas, ou seja, de que alguém possua um conhecimento para concretizar tais práticas (no caso, o supervisor) e poderá ensiná-las a quem não sabe (trabalhadores)?

A supervisão, sob este ponto de vista, assume uma dimensão que transcende a questão da formação e do próprio campo da saúde mental. Na fala de um supervisor:

“ Essa supervisão não é só parte da Saúde Mental, é parte de todo campo de saúde ... Uma supervisão na realidade é para trabalhar o caso, mas também o terapeuta, o psicólogo e todos que trabalharem (nessa área)... É então um suporte do trabalho da saúde. É necessário que outra pessoa escute o que acontece entre o profissional e o paciente e seu comprometimento."

Dessa forma, tais expectativas, sob nosso ponto de vista, jamais poderiam ser contempladas nos grupos de supervisão por dizerem respeito a questões mais amplas, relativas à definição de diretrizes políticas e organização dos serviços. 
2. Integrar e organizar os serviços. Integrar e definir papéis profissionais dentro da equipe.

"Sou psicóloga de (UBS). ... não há uma definição de função muito clara. A minha expectativa é ter uma maior clareza com a questão do manejo, que compreensão podemos ter do manejo do caso ...”

"Sou da UBS X. Estou há seis meses neste ramo, antes eu era clínica. (Tenho) expectativa de supervisão institucional. No início do ano teve a remoção e a formação da equipe nova: duas psicólogas, uma terapeuta ocupacional, fono fisioterapeuta, assistente social. Até junho todo mundo trabalhava sozinho. Com a chegada da fisio, T.O. e fono passou a haver uma reunião com todos. Com a supervisão (espero) ter a estruturação da equipe. De manhã é um posto, à tarde é outro, à noite é outro."

“...integrar o serviço. É nisso que eu estava interessada para a supervisão.”

"A minha expectativa é um pouco diferente. Seria mais para trabalhar a relação na equipe que eu trabalho, porque esta coisa de troca a gente já tem lá.”

Tais expectativas dizem respeito à busca de definição da estruturação do serviço, de clarificação dos conteúdos da proposta e não poderiam ser sanadas a partir da supervisão.

A partir de tais expectativas podemos também fazer indagações sobre o tipo de relação instalada entre trabalhadores e representantes da administração pública no contexto dos serviços de saúde. Esperar que a integração dos serviços possa se dar a partir de discussões realizadas em pequenos grupos de supervisão, os quais não incluem representantes das diferentes esferas institucionais, responsáveis pela definição das diretrizes e pela viabilização dos recursos para colocá-las em prática, denota uma postura de idealização do papel do supervisor/supervisão frente aos profissionais e de distanciamento entre eles e os responsáveis pela estrutura organizacional da instituição.

Mais uma vez, podemos relacionar tais questões à necessidade de delimitação de novas fronteiras neste trabalho: quem pode ser responsabilizado pelo quê no contexto institucional?

A falta de clareza, às vezes, identifica-se com problema pessoal, como falta de maturidade profissional.

"Essa coisa de imaturidade profissional é permanente. Sou formada há tantos anos e ainda me sinto despreparada. Espero poder fazer aqui algumas discriminações: o que é o limite institucional, do outro. Eu preciso saber o que é da instituição e o que é meu. Deve haver alguma linha divisória que permita pensar nisso.” 
Podemos depreender daí outra expectativa dos trabalhadores.

3. Supervisão como análise institucional, como possibilidade de sanar problemas de relacionamentos da equipe e da própria instituição.

“... Eu sinto uma necessidade lá na UBS de uma supervisora no local. O ideal para mim é que o supervisor fosse até a UBS ... a minha necessidade seria na instituição para garantir a equipe.”

"O HD teve uma época que teve supervisão para toda a equipe ... eu achei que funcionou bem. (Este) é um grupo muito grande, de unidades diferentes, de formações diferentes, o que é ótimo. Mas eu sinto falta de supervisão para o manejo que aqui não caberia."

"Tenho expectativas tanto institucional ... a questão da equipe de saúde mental não é coisa fácil de se formar. Eu não fiz residência, mestrado ... Na instituição tem determinadas coisas que a gente vai se esbarrar, às vezes a gente esquece que está numa instituição...”

A necessidade de que alguém de 'fora' esteja junto do trabalho em equipe aparece relacionada à emissão de critérios de 'verdade' que tragam elementos de avaliação sobre a prática desenvolvida. Busca-se o veredicto sobre a normalidade institucional, o qual deve ser dado por alguém que não pertença a ela e que possua um determinado saber.

"A expectativa é que o trabalho nessa administração é novo. A supervisão é ver se é coerente o trabalho, o Projeto."

"Entender melhor como o trabalho se dá."

"Dificuldade de discutir certos problemas. Qual o percurso que nós e os pacientes fazemos?”

A dificuldade apontada diz respeito ao tipo de relação instalada nas equipes, no contexto institucional. Discussões em equipe, reuniões gerais da Unidade de Saúde fazem parte da rotina institucional, mas nem sempre apresentam os resultados esperados. As dúvidas quanto ao próprio conhecimento e ao do 'outro', juntamente com possíveis discordâncias ideológicas, impedem os resultados esperados no encontro das equipes. Nesse sentido, mais uma vez a supervisão ocupa um lugar de preencher as falhas no trabalho de implantação. 
4. Expectativa de 'troca' (intra/inter equipes e inter-institucional) de conhecimentos, de vivências, de práticas ...

“Estou na prefeitura há quase 20 anos ... Tenho uma expectativa quanto à supervisão de nos conhecermos e podermos levantar algumas questões que estão emperradas. A expectativa não é muito grande, não.”

“... expectativa de ouvir o que cada um sente no trabalho, problemática específica dos lugares que trabalho. Receio que essas conversas tomem rumo de serem mais administrativas.

“... expectativa de troca de vivências. Isto é algo importante.”

“... expectativa da possibilidade de troca ao trabalhar com diferentes profissionais.”

"Acho importante aqui (na supervisão), a gente estar trocando experiências, estar pensando os recursos utilizáveis, quais as alternativas..."

"Em saúde mental temos que ter espaço para conversar para ter outras referências, para podermos, por exemplo, no caso de encaminhar para outro profissional.”

A expectativa de 'troca’ esteve presente intensamente nos grupos de supervisão. Estamos entendendo a 'troca' como a possibilidade de se trabalhar em equipe a partir da inclusão de diferentes referenciais nas ações e reflexões sobre a prática. Ou, em outros casos (algumas UBSs, por exemplo), como forma de romper com o isolamento de um trabalho que não é desenvolvido em conjunto.

Levantamos a hipótese de que há uma fantasia entre trabalhadores de que a convivência com tantas diferenças pode ser arriscada, se não houver a presença de algum ‘apaziguador’ das possíveis tensões que se estabelecerão nesse contato. Mas, apesar dos riscos que se corre, tal convivência é fundamental, pois sem 'troca' não há novo trabalho. Nesse sentido, a supervisão assume uma importância vital para os trabalhadores:

“Acho impossível hoje trabalharmos sem esse espaço da supervisão.”

Contudo a instalação da supervisão não garante que haja maior fluidez nas discussões e que os riscos deixem de existir. Ao contrário, muito dos impasses e da paralisia do dia-a-dia do trabalho se reproduzem nesse espaço. 


$$
\begin{aligned}
& R \text { - "Esse espaço ... eu nem sempre me sinto à vontade ...sinto o grupo todo } \\
& \text { mundo contido ... eu me incluo." } \\
& H \text { - "Dificuldade de se expor ... Você enquanto supervisora, vai avaliar o } \\
& \text { nosso trabalho ... dificuldade de se expor e de ter um retorno..." } \\
& \text { (noutra sessão) } \\
& R \text { - “Não rola, não fala ... supervisão é uma coisa que todo mundo }
\end{aligned}
$$
batalhou ... a gente vem e não sai nada.”

Outro grupo:

"Eu acho que precisava estar todo mundo junto ... num espaço sagrado que é a supervisão ... Eu ... acho que é mais fácil a apresentação (de casos clínicos) num espaço mais protegido que é o da supervisão..."

'Local sagrado', 'espaço protegido' são expressões sobre a supervisão que a coloca num lugar idealizado pelos trabalhadores e que poderá retirá-los de seu difícil cotidiano, além de representar uma possibilidade de avanço no trabalho.

Mesmo sendo espaço 'sagrado' e 'protegido', a discussão de casos é muito difícil. No encontro onde surgiu a fala acima, o supervisor havia colocado como tarefa a discussão de um caso ou do funcionamento das mini-equipes, mas nenhuma delas vingou. Freqüentemente, a não realização da tarefa passa a ser justificada pelos problemas relacionados à dinâmica da própria instituição.

No relato sobre o funcionamento da instituição, repetem-se dificuldades relativas aos limites, semelhantes às colocadas no trato aos pacientes, principalmente com os “psicóticos”.

C: "A gente não elegeu um paciente mas podemos eleger."

I: "Não deu tempo... Foi uma absoluta loucura. Acho que a gente podia rapidinho eleger. Era bom a gente pegar a nossa grade?"

Supervisor: "O que é a grade?”

I: "É como se organizam os trabalhos"

Supervisor: "Então traz para eu ver. Vocês estão dentro (do serviço), mas eu não

estou.”

Podemos depreender desse trecho duas questões. Uma diz respeito à reprodução da 'loucura' institucional, das ações desenvolvidas 'às pressas' (eleger rapidinho um caso) no próprio espaço de supervisão. Outra, ao duplo lugar ocupado pelo supervisor entre os trabalhadores. A discussão sobre a 'grade' é ilustrativa nesse sentido.

Esta é descrita na instituição como a forma de arrolar e delimitar as atividades, considerando os locais e os horários em que são desenvolvidas. De certa forma, representa o 
controle dos profissionais sobre suas atividades. ${ }^{210}$ Mas, este é um termo utilizado pela equipe e desconhecido pelo supervisor (ele acentua o fato de não pertencer à instituição e não dominar certos termos). Essa situação nos remete a dois lados de uma mesma questão: ao utilizarem termos que apenas eles conhecem, demonstrando o controle sobre seu trabalho, por um lado, excluem o supervisor e, por outro incluem-no, como se a ele também pertencessem os códigos estabelecidos na convivência cotidiana de trabalho.

Os trabalhadores, nessa situação, demostram certo grau de independência em relação aos conhecimentos do supervisor. Eles também possuem informações (conhecimentos), cujo domínio e entendimento somente a eles lhes pertencem. Nessa situação o supervisor é excluído.

Entretanto, ao utilizarem tais termos como se fossem conhecidos do supervisor, este passa a ser incluído nesse universo e pode se transformar em aliado na constituição de um espaço próprio, independente da instituição. Cria-se a ilusão de que a constituição de espaços privados, independentes, possam substituir os fóruns deliberativos de implantação da proposta. $^{211}$

“ A proposta clínica na prefeitura não está muito bem demarcada. Acho que aqui pode ser um fórum de discussão do qual surgem idéias e que podem ser concretizadas em determinadas situações.”

Sob este ponto de vista, a supervisão parece, muitas vezes, constituir-se num espaço privado e independente em relação ao que ocorre fora dela. Levantamos essa possibilidade pautados também no número significativo de grupos instalados pelos próprios trabalhadores, em que eles arcam com os custos de contratação do supervisor. A partir dos relatos analisados, percebemos também que, algumas vezes, os grupos por eles custeados eram mais valorizados do que aqueles instalados no Projeto de Formação.

$\mathrm{K}$ : "Eu estou particularmente dividida, pois eu tenho a história da outra supervisão que acontece há 5 anos extra-oficialmente e que se desarticulou um pouco com essa supervisão. Eu acho que a gente tem que ter uma visão mais global; articular essas experiências, sem que uma prejudique a outra..”

${ }^{210}$ Os próprios trabalhadores têm uma visão crítica sobre a utilização desse termo. Um terapeuta ocupacional ao apresentar, no IPUSP, o trabalho desenvolvido no Hospital Dia em que trabalha, pontuava o sentido ambíguo da palavra grade, que apesar de representar a organização do trabalho na instituição é o termo de contenção. Representa as grades da cadeia ou da própria estrutura manicomial.

${ }^{211}$ Importante lembrar que durante os quatro anos de governo havia fóruns deliberativos com representação de trabalhadores, usuários e administração (as comissões gestoras). Além disso, havia grupos de trabalhos, encontro de trabalhadores para discussões relacionadas à implantação do modelo de saúde, incluindo o programa de saúde mental. 
$\mathrm{J}$ : "Eu acho que a gente tem essa alternativa de continuar se todos quisessem aqui. (Fala sobre a outra supervisão, da coesão do grupo que possibilitou a continuidade) Não estou indo lá agora por questões pessoais, mas o pessoal sabe que é temporário.”

M: "Eu fico dividida com isso. Para mim fica meio autoritário, você tem que participar dessa supervisão que é a oficial, a outra fica de lado.”

Esta última fala marca um desmérito em relação à experiência vivida na supervisão oficial e expressa de certa forma uma dicotomia entre trabalhadores $X$ instituição ${ }^{212}$. Nessa situação, expressa-se um certo 'descaso' em relação à instituição, e com este, um sentimento de onipotência dos trabalhadores: as ações instaladas pela instituição não são tão boas quanto aquelas patrocinadas por eles próprios. Esta tendência pode ser alimentada pelos supervisores, dependendo do tipo de aliança estabelecida entre estes e os trabalhadores. A dicotomia (independência) em relação à instituição acentua-se. ${ }^{213}$

Supervisor - "Sim, tudo bem." (Afirma que gostaria de continuar com o grupo, mas o espaço no qual estão instalados não poderia ser o mesmo se a supervisão não continuar oficialmente.) Mas a gente pode ir pro consultório. Mas teria outro contrato então. Quem tiver topando fazer um novo contrato, e aí vai ter que pagar, mas isso a gente resolve depois, estou aceitando propostas. Vocês sabem quanto eu estou cobrando, não é? Vocês acham que podem ir no consultório semana que vem pra ir conversando?

A partir das expectativas levantadas pelos trabalhadores, apontamos até aqui questões que dizem respeito ao lugar ocupado pela supervisão como dispositivo de formação, à relação de dependência/independência dos trabalhadores diante dos supervisores e destes em relação à instituição.

A supervisão como mecanismo de formação tem ocupado um lugar ambíguo no contexto de implantação da rede. Se, por um lado, apresenta-se como fundamental para a mobilização das equipes de trabalho (concretizam-se espaços de troca, efetuam-se discussões sobre casos clínicos e concepções mais abrangentes no trabalho em saúde mental, evidenciamse alguns dos limites impostos pelo alto índice de demanda dos serviços e os recursos oferecidos pela instituição etc.), por outro, ela pode vir a se fundir às indiscriminações instaladas no cotidiano de trabalho.

${ }^{212}$ A instituição está sendo entendida nesse momento como o conjunto de recursos e relações estabelecidas no âmbito da Secretaria Municipal de Saúde, representada pelas instâncias gerenciais.

${ }^{213}$ A aliança trabalhadores/supervisores em oposição à instituição pôde ser explicitada em alguns grupos a partir do desenvolvimento do processo de investigação sistemática incluída no projeto, representado pela figura do observador presente em parte dos grupos de supervisão. O contrato assinado pelos supervisores previa essa participação. No entanto, houve algumas reações, principalmente por parte dos supervisores, por entenderem que isto implicaria interferência na condução do trabalho. Além da inclusão dos observadores, outro fato chamou nossa atenção. Em alguns grupos havia o interesse de assessores de saúde mental (representantes da administração) participarem dos grupos por entenderem que a construção de novas práticas se daria a partir de um esforço conjunto. Mas a entrada destes era amplamente discutida, em alguns casos foi barrada, por ser considerado que essa participação não deixaria os trabalhadores e supervisores à vontade. $\mathrm{O}$ que mais nos surpreendeu foi a postura 'humilde' dos assessores, acatando a decisão do grupo, como se realmente esse espaço não fizesse parte do conjunto de práticas institucionais. 
O conjunto de expectativas dos trabalhadores, apontadas em relação a essa prática de formação, mesclam-se a diferentes tipos de demandas, as quais não poderão ser atingidas por transcenderem os limites que dizem respeito às ações voltadas para formação. ${ }^{214}$ Podemos considerar que há um pedido por parte dos trabalhadores, que inclui diferentes aspectos a serem contemplados na supervisão. A diversidade de expectativas depositadas na prática de supervisão mobiliza grande número de trabalhadores. No entanto, ao se depararem com a impossibilidade de tê-las contempladas, emergem sentimentos de frustração em relação a esta prática: há um esvaziamento de investimento nesses grupos (ausência física, abandono dos grupos).

Tantas expectativas depositadas nos grupos de supervisão nos remetem mais uma vez à idéia de (perda de) 'limite’. Ao contrário da formação universitária, a supervisão passa a ser qualificada como fonte inesgotável de possibilidades, mesmo que não se possam concretizálas. Ao ser fonte inesgotável, institui-se como ‘necessidade eterna' (enquanto a instituição ou eles próprios puderem arcar com seus custos financeiros, sua duração é indeterminada). Por ser ilimitada, não são colocados objetivos claros e instala-se uma relação de dependência dos trabalhadores. Esta dependência parece estar a serviço de terem seu próprio espaço e diminuir a frustração colocada em relação às limitações do trabalho institucional. Consideramos que esta relação pode impedir o amadurecimento e a expressão da atividade criativa da equipe de trabalho.

Considerando o lugar ambíguo ocupado pela supervisão no âmbito das práticas antimanicomiais podemos indagar sobre seus limites como mecanismo de formação: até que ponto ela pode cumprir com esse papel? Trata-se de mais um tipo de delimitação a ser construída para a implantação das práticas antimanicomiais.

A questão da dependência $X$ independência está ligada às relações dos trabalhadores, não somente em relação à supervisão e aos supervisores, mas também, à instituição. A construção de outros limites se impõe: numa prática coletiva e institucional não há possibilidade de total independência, como também a dependência em excesso tolhe a possibilidade de criação. Discutiremos mais sobre este ponto no próximo tópico.

214 Deve ser considerado que a supervisão pode permitir certa discriminação desses aspectos dependendo da relação estabelecida entre supervisor e trabalhadores. 


\section{4 - A construção de novas práticas e os ideais antimanicomiais}

Ao lançarmos nosso olhar sobre a rede substitutiva de saúde mental implantada no município de São Paulo, pudemos identificar conflitos no cotidiano de trabalho emergentes, entre outras, de contradições que se dão entre os ideais antimanicomiais e aqueles herdados da psiquiatria clássica. Relacionamos tais conflitos com questões que dizem respeito à concepção de loucura/doença mental e à ampliação dos espaços tradicionais de atendimento psiquiátrico; à estratégia de rompimento/superação do saber e prática médica (constituição da equipe multiprofissional); e à formação dos trabalhadores envolvidos nas novas práticas.

Neste tópico, dirigiremos nosso olhar para a relação estabelecida entre os trabalhadores e a ‘instituição’ (unidades de saúde que compõem a rede, relações hierárquicas dessa estrutura, diretrizes políticas etc.) na qual estão inseridos. Questões que dizem respeito à dependência $X$ independência dos trabalhadores nessa relação assumem um aspecto relevante e merecem ser destacadas.

As modalidades de inserção institucional oscilam entre aderência e recusa destes profissionais em relação às ofertas institucionais. Desse modo, ora eles tentam 'colar' sua prática ao modelo oficial e aos princípios antimanicomiais nele contidos, esperando obter o reconhecimento institucional de seu trabalho; ora abandonam diretrizes do modelo, questionam os princípios antimanicomiais e negam as implicações políticas da estrutura institucional.

“A gente roda, roda roda,, ... que modelo de hospital dia é esse e para quem é indicado... Tem um atravessador na minha opinião ... o quanto que tem de discordância em relação ao modelo oficial.”

“.... Eu acho que a gente está caminhando para uma autonomia. Qual seria então o modelo para essa região? Dane-se o modelo maior. Eu acho que isso é algo que nos une aqui, a gente falar das faltas, dos problemas. Outra coisa que nos une é algo da técnica, ou pra uma discussão de tema, ou de caso, acho que isso enriquece."

Podemos depreender das falas acima uma discordância dos trabalhadores em relação às diretrizes preconizadas oficialmente. Entretanto, apesar de levantarem a possibilidade de prescindir do modelo oficial, circula entre eles a preocupação em corresponderem às expectativas institucionais.

“... A gente tá sempre com uma sensação que fez pouco...”

“É muito verdadeiro o drama de estar numa instituição e não ser reconhecido.” 
“Nas reuniões sente-se que há uma grande cobrança sobre a questão do tratamento dos psicóticos e eu não me sinto aparelhada para estar lidando com isso.."

Autonomia em relação ao programa oficial e busca de um desempenho que corresponda às expectativas institucionais expressam representações ambíguas dos trabalhadores em relação a sua auto-imagem e a sua inserção no trabalho. Ora desvalorizam a proposta institucional e se consideram capazes de criar a prática independentemente do que preconiza a política oficial; ora se auto-desvalorizam, atribuindo a si próprios a falta de conhecimento, de entendimento sobre o modelo e sobre o instrumental voltado para a concretização da proposta.

Neste sentido, podemos, mais uma vez, identificar questões relacionadas ao saber $X$ não saber no âmbito das práticas. Trata-se agora de indagações sobre o que se sabe sobre o modelo, sobre os princípios antimanicomiais que o fundamentam e, principalmente, sobre o lugar que ocupam na instituição.

F: “ ... acho que a gente tem uma importância sim, porque a instituição não daria esse espaço dentro do programa se ela não considerasse a nossa importância”

H: "O fato de você constatar uma impotência não quer dizer que tudo foi

errado.”

A: "Eu estou com os dois, parece que a F. diz que a instituição nos vê como adultos, e as outras (pessoas) estão falando de que a instituição nos vê como adolescentes. É isso de estar cá e lá, a instituição fica como pai e mãe, tem algo de buscar uma identidade dentro da instituição.

$V$. "Tem a ver com como a gente se vê. Uma vez eu estava como delegada numa conferência de saúde mental e havia muito debate sobre a antipsiquiatria. Os profissionais da área lá estavam sendo muito atacados. ... Eu fico pensando o quanto a gente se valoriza ou não se valoriza."

Valorizar $X$ desvalorizar o modelo oficial ou seu próprio trabalho, ser valorizado $X$ desvalorizado pela instituição ou equipe representam outras manifestações emergentes nesse processo.

"O discurso que permeia a administração ${ }^{215}$ é o de dar conta de toda a demanda. É difícil lidar com a culpa que isso gera. É preciso delimitar a capacidade própria para dar mais segurança. Alivia o fato de saber qual é o meu limite.”

${ }^{215}$ Administração é um termo muito utilizado para identificar os representantes do governo que ocupam cargos de gerência, de assessoria etc. 
“Dentro dessa questão do limite, e aquele paciente que não foi atendido e acaba por, por exemplo, se suicidar. ... É uma responsabilidade profissional. É uma questão ética. A equipe não pode se omitir de atender. Há uma grande responsabilidade. É preciso extrapolar a questão do limite quando é percebido um caso grave.”

“Tudo tem limite, nós também, é um grande ataque à auto-estima. ... O paciente muitas vezes não se sente atendido; ele se assusta ao chegar num grupo de trinta, trinta e cinco pessoas. ... Tem uma questão ética também, questão do público e do individual. ... A gente tem que partir de alguns princípio básicos, por exemplo o limite de pessoas, a afinidade com o trabalho. ... Existem algumas características que a gente tem que definir para a equipe não mergulhar na loucura com as pessoas."

“As coisas não podem ser tão dicotomizadas, atender todos ou não. Pondo vinte pessoas numa sala você estará atendendo? Daí não dá para perceber um mais quieto, que pode ser o caso mais grave. A responsabilidade entra na questão desse fazer de conta que se atende."

“... de novo a gente cai na culpa. É preciso ter em mente o limite; a responsabilidade não é só nossa, é também de toda uma situação.”

A 'falta de limites' na construção de práticas manifesta-se mesclada a sentimentos de culpa/raiva pela responsabilização de ações atribuídas aos profissionais e que nem sempre se sentem capazes em cumpri-las: o que considerar como caso grave (ou não)? Quais os limites entre coletivo (grupo) e individual? Entre público e privado? Em outros termos, tais questões nos remetem à necessidade de ressignificação de 'outras fronteiras' referentes à proposta e ao conjunto de conhecimentos acumulados, seja socialmente, seja pela experiência dos trabalhadores.

Tais questões, por outro lado, mesclam-se aos limites concretos colocados na consecução da prática. Estes dizem respeito à realidade social e política de nosso país, ou seja, às condições de vida e de trabalho às quais estão submetidos, respectivamente, população ‘usuária’ dos serviços e trabalhadores.

Faz-se necessário lembrar que as formas de investimento governamental nas áreas sociais em nosso país não satisfazem. Os problemas de saúde, geralmente decorrentes das condições sociais, são de diversos tipos de gravidade e atingem altos índices de prevalência. Os recursos destinados a essa resolução são insuficientes. Esforços isolados de esferas do governo (municipal, estadual ou federal) ou investimentos em áreas sociais particulares são benvindos, mas não suficientes para a resolução de problemas relacionados à condição de vida a que está submetida a população.

Na área de saúde, os trabalhadores têm-se deparado com grande fluxo de pacientes procurando seus serviços. Contenção de demanda passa a ser uma questão fundamental e esses profissionais tomam para si a responsabilidade de atendê-la. 
“Eu acabei me sobrecarregando com a idéia de poder atender a todos. Hoje não me proponho a atender toda a população que bate a minha porta; não é possível para mim. Eu tive que brecar a demanda para dar maior qualidade de atendimento, para criar vínculo.”

“A pessoa tem que ter claro a questão do limite. Se houver a ilusão de que se pode atender a todos, mais dura é a frustração. ... Há uma sensação de impotência.”

“Falar em quantidade ameaça a qualidade. É preciso discutir como conciliar as duas coisas.”

“O posto recebe pessoas de várias regiões, as pessoas não recebem atendimento na região em si. As pessoas da nossa região a gente já não consegue absorver. Há discussão sobre esse critério de atender as pessoas da região. As pessoas vêm de lugares muito distantes”

“O problema não é quantidade, mas qualidade. Temos queixas de drogas, espancamento, AIDS, alcoolismo em adolescentes, suicídio em adolescentes. Há preocupação não na triagem, mas na real possibilidade de atender esses casos. ... É questão de instrumental e potência, ver a real possibilidade. São casos que (buscam) o judicial , o social...”

Os sentimentos de impotência $X$ onipotência se fazem presentes também nestas tentativas de conter a demanda. Estas podem depender em alguns aspectos da ação da equipe na unidade de trabalho (definição de critérios para a sua organização a partir de um planejamento estratégico, por exemplo). No entanto, tal questão diz respeito à realidade mais ampla que transcende os espaços de cada unidade de saúde. Está relacionada à estruturação do sistema geral de saúde no âmbito das políticas públicas.

Considerando tais aspectos, podemos afirmar que muitas vezes os trabalhadores não contextualizam sua inserção institucional nessa realidade. Nesses casos, eles têm um entendimento racional sobre a situação geral do sistema e conhecimento sobre as péssimas condições de vida da população atendida nos serviços. Entretanto, a 'vivência subjetiva' relaciona-se mais ao seu desempenho individual e às expectativas institucionais.

É certo, neste contexto, que o grande número de pessoas a serem atendidas causa muita angústia seja nos trabalhadores, seja nos representantes da administração.

"É preciso ter um registro dessa demanda sufocada, daqueles que não foram atendidos, é preciso dar uma solução para isso; é uma angústia compartilhada com a instituição, com a administração.”

Essa realidade, contudo, se apresenta com características paradoxais. A pressão da demanda é uma problemática na organização dos serviços, mas afeta as unidades de forma 
diferenciada. Equipamentos específicos de saúde mental, os quais não são 'porta de entrada' da rede, padecem menos desse problema. Em alguns casos, contraditoriamente à lógica do sistema, alguns deles buscam preencher sua capacidade de atendimento. Nos HDs, por exemplo, a discussão em alguns grupos de supervisão se deu mais em função da definição do tipo de atendimento prioritário, privilegiar casos de pacientes 'agudos' ou incluir também pacientes crônicos (ao contrário do que preconizava a proposta oficial). Essa definição implicaria outro tipo de transgressão ao modelo, ou seja, a ampliação dos limites estabelecidos referente ao tempo de permanência dos usuários na unidade. Optando-se pelo atendimento de pacientes crônicos, tal permanência excederia à estipulada pela proposta original.

“Estamos com vaga sobrando e não tem paciente ... Esse hospital dia faz parte de uma programa oficial...”

“Então a gente estava atrás do agudo e não pegava o crônico ... No fim nós acabamos ficando com o crônico...”

“... Nessa hora, a gente lembra do modelo de novo ... ficar voltando nessa questão, estava previsto três meses (de permanência dos usuários no HD) e ele já está há nove. Nós estamos subvertendo esse modelo.”

Podemos dizer que as diferenças atribuídas a unidades de uma mesma rede de atenção em saúde mental produz diferentes tipos de questões emergentes no contexto de trabalho. Unidades como UBS e Pronto Socorro, por funcionarem como 'porta de entrada' e por serem antigas conhecidas da população, são as que mais sofrem com excesso de demanda. Apesar disso, principalmente as UBSs, deparam-se com certo tipo de demanda reprimida em relação àquela que seria a prioridade dos atendimentos.

A - "Não tem chegado este grupo de risco nas UBS.

$B$ - "Chega um ou outro, mas é minoria. ... Saber quanto a UBS pode atuar nesta área. Se cabe um psicótico no posto ou não. Acho que é isso que preocupa os profissionais.”

A fala acima nos remete também a questões relacionadas à pertinência (ou não) do atendimento específico em saúde mental nas unidades gerais. Tal indagação diz respeito, mais uma vez, à relação entre modelo preconizado pela 'administração' e possibilidades 'concretas’(dos trabalhadores) de sua implantação. Discutiremos tal questão mais adiante.

No momento, devemos destacar que além de tais unidades serem "porta de entrada”, sua organização do serviço está voltada para a atenção em saúde geral. Tal característica acentua a forma diferenciada de inserção da equipe de saúde mental nessas 
unidades, quando comparada aos equipamentos específicos. Estes últimos (principalmente HDs) possibilitam um maior entrosamento da equipe e, conseqüentemente, o avanço relativo às formas de atenção em saúde mental voltadas a pacientes psiquiátricos. A delimitação dos tipos de casos a serem atendidos, apresenta-se menos complexa do que nas unidades gerais.

Nas UBSs e PSs, ao contrário, a equipe de saúde mental, além de se ater à especificidade e identidade da equipe, trabalha junto a outros programas e se depara cotidianamente com a questão de limitar diferentes tipos e grandes quantidades de demandas. $\mathrm{O}$ trabalho da equipe de saúde mental junto à totalidade de profissionais destas unidades, sejam técnicos ou não técnicos, vem permeado por um certo 'grau de estranheza', o qual tradicionalmente é atribuído aos profissionais que lidam com 'loucos'. Podemos depreender daí uma outra modalidade de cisão entre os trabalhadores no contexto de trabalho: equipe de saúde mental $\mathrm{X}$ equipe geral da unidade.

Vale ressaltar que nessa relação, mais uma vez, os trabalhadores em saúde mental aparecem identificados aos usuários 'loucos' dos serviços. Essa cisão pode resultar na (auto)exclusão da equipe de saúde mental dentro da unidade. Podemos compreender tal fenômeno como atualização da segregação vivida pelos 'doentes mentais' no meio social. Ou, em outros termos, como efeito de representações sociais que extrapolam o âmbito das instituições da saúde. Nestas tornam-se 'estranhos’ não apenas os excluídos socialmente, mas também aqueles que com eles convivem. ${ }^{216}$ Desse modo, a identificação dos trabalhadores em saúde mental com os usuários não 'brota' pura e simplesmente de 'dentro de si', mas é construída e vivida nas relações sociais concretas.

"Fico pensando o papel dos colegas que trabalham em outras unidades (não específicas). Como fica o papel desses colegas dentro da equipe? Como a saúde mental se integra mais amplamente dentro da unidade? Como atua com outros profissionais?

"Há algo de adolescente no Posto de saúde, há uma segregação dos grupos de saúde mental.”

${ }^{216}$ Goffman inclui na discussão sobre estigma, uma categoria de indivíduos dos quais os estigmatizados podem esperar algum apoio. Utilizando uma expressão que circula entre os homossexuais, vai considerar 'informados' os indivíduos que "são normais, mas cuja situação especial levou a privar intimamente da vida secreta do estigmatizado e simpatizar com ela, e que gozam, ao mesmo tempo, de uma certa aceitação, uma certa pertinência cortês ao clã.” Um dos tipos de pessoa informada é aquela cuja informação vem do trabalho, ou seja, pessoas que trabalham junto a eles. Exemplo destes são os profissionais que compõem as equipes de saúde mental. Outro tipo de pessoa 'informada' é aquela que se relaciona com o indivíduo estigmatizado através da estrutura social - "uma relação que leva a sociedade mais ampla a considerar ambos como uma só pessoa." Incluem-se nessa categoria os familiares desses excluídos. (Goffmann, E. Estigma: notas sobre a manipulação da identidade deteriorada. Rio de Janeiro, Zahar, 1992, p. 37 e 39) Podemos dizer que no contexto das instituições de saúde os profissionais de saúde mental são identificados com os pacientes pela totalidade da equipe, do mesmo modo que os familiares são com seus membros estigmatizados. 
"Vocês estão me surpreendendo, porque quando eu cheguei aqui eu pensei que a gente aqui estivesse numa boa. Porque antes a gente não tinha nem um papel escrito saúde mental, o chefe nem sabia o que cobrar da gente. Eu achei que a gente conseguiu um certo respeito hoje. Agora as pessoas estão sabendo mais do que a gente faz. E de repente você me puxou o tapete..."

Retomemos questões que dizem respeito ao descompasso entre diretrizes oficiais e a forma como estas são apreendidas ou modificadas pelos trabalhadores.

"Tem um modelo que me incomoda que é por exemplo que a UBS deve atender psicóticos. Esse modelo é muito simplificador. Precisa saber quais são os recursos que se tem para viabilizar isso. Tem determinadas características da região que devem ser levadas em conta, não que a gente vai conseguir mudar tudo. Algo que me interessa é perceber as dificuldades e as possibilidades.

"Lá no posto (UBS) ... criança psicótica não é a minha preferência, não escolhi trabalhar com isto. Mas por outro lado o X (assessor de saúde mental do Distrito de Saúde) tem colocado como se a gente tivesse medo. Eu não sei se é medo que eu tinha. Conheço gente que trabalha com isto, que optou por questões teóricas e que se dá muito bem. Não tenho um aprofundamento teórico, já atendi ... não sei se é da ordem do medo, acho que é uma questão institucional

"O HD seria uma forma diferente, nova. E de repente, eu senti que não é bem o que a gente está vivendo aqui ... mas o como essas coisas são conduzidas de uma forma tradicional. ... Tenho uma vontade grande de fazer com que isso seja diferente. A gente trata com atenção, mais delicadeza, feito gente. E eles não dormem aqui. São as diferenças básicas. A medicação é tão forte quanto nos hospitais."

Podemos perceber que questionamentos sobre o modelo oficial não são exclusivos de um ou outro equipamento, mas se apresentam como uma constante indagação na prática diária dos trabalhadores. Estes podem ser entendidos sob dois aspectos: um diz respeito às questões de ordem subjetivas emergentes das contradições colocadas pelo próprio modelo antimanicomial. Nesse caso a instituição representa a materialização de tais princípios a partir dos projetos que devem ser colocados em ação.

Outro aspecto refere-se a questões de ordem objetiva, da própria organização dos serviços e da precariedade de condições materiais, às quais muitas unidades podem estar submetidas.

"Sou do Pronto Socorro. São duas plantonistas por dia, trabalhamos sem estrutura nenhuma. A gente faz o atendimento do paciente no leito. Não há sala. A gente não faz 
só trabalho com os pacientes em emergência, mas também com os familiares. ... Estamos tateando ainda, há muito o que fazer.”

“No posto a gente tem os profissionais, mas não tem o espaço, salas..."

"Sou psicóloga, trabalho num mini posto. Sou sozinha, tem uma assistente social, eu trabalho há 11 meses. Eles não me esperavam, ficaram surpresos com uma psicóloga, mesmo porque não tem sala. A demanda é muito grande, principalmente de crianças. Eu não tenho experiências com crianças. A sala que faço atendimento é dois por dois ... Sinto dificuldade de realizar trabalhos lá: a questão do espaço, de não ter outro psicólogo. Tem enfermeira, educadora e assistente social. Faço atendimento individual, não tenho condições de atender crianças, parei. a sala de atendimento foi ocupada para almoxarifado.”

Aspectos subjetivos e objetivos envolvidos nas práticas se misturam e só fazem aumentar o descompasso como apontamos acima, entre política oficial (administração/instituição) $\mathrm{X}$ prática implantada (trabalhadores). A relação trabalhadores $X$ instituição caracteriza-se por desentendimentos, dúvidas e desconfiança. Desconfiança sobre os ‘objetivos secretos' que a instituição pode ter em relação aos trabalhadores. ${ }^{217}$ Além disso uma desvalorização da instituição explicita-se a partir da indagação sobre a capacidade de seus gerentes e a competência da administração.

“Quem coordena a saúde mental não compreende a saúde mental.”

"Eu acho que a administração quis transparecer que existia mais um compromisso político partidário e não com a população e por isto perderam a eleição.”

“Existe a proposta teórica, mas (esta) não foi realizada...”

Aos questionamentos vinculados à relação entre as diretrizes oficiais e a possibilidade de sua concretização, associam-se outros sobre alguns dos princípios antimanicomiais e sua repercussão na prática. Em alguns casos, a suspeita sobre a validade destes princípios impulsiona o trabalhador a desenvolver uma postura de negação do trabalho coletivo e priorização de ações individuais. Em outros casos, tenta-se negar as dúvidas e transformar tais princípios em 'crenças', as quais poderão protegê-los da desestruturação possível diante do caos. Em ambos os casos instalam-se a paralisia no processo de criação no trabalho.

\footnotetext{
${ }^{217}$ Até mesmo a implantação do Projeto de Formação Permanente em Recurso Humanos na Área de saúde mental, tão reivindicado durante os quatro anos, sofreu recusas e questionamentos por parte dos trabalhadores. Havendo ou não a destinação de recursos para implantação de propostas, freqüentemente, há desconfianças.
} 
“É tão forte a idéia do antimanicomialismo ... Eu não estou criticando a idéia, mas ela é tão forte ... Somos tão contrários ao manicômio que não se consegue pensar.”

“Tem projetos que são irreais, englobam muito mais do que a gente poder fazer. Tarefas da Saúde Mental não tem a ver com o nosso trabalho. A gente entra numa escola sem a menor condição. Não vai adiantar nada. É tão amplo que não se chega a nada.”

“O discurso é supervalorização do coletivo ... onde fica optar por um tipo de trabalho público que não seja necessariamente as ações coletivas.”

“Eu acho que o nosso trabalho é curativo e não preventivo."

“Essa ação coletiva é uma boa maneira do profissional se evadir do seu trabalho.”

Na complexidade do trabalho de implantação de novas práticas em saúde mental, vão, contudo, sendo desenvolvidos mecanismos de sobrevivência na instituição. Um retorno para as ações individuais resgata aparentemente uma vivência de autonomia e recusa frente a tantas determinações.

Além disso, é importante mencionar que o entendimento dos trabalhadores sobre os princípios antimanicomiais não se apresenta de forma homogênea. Pelo contrário, às vezes, restringe-se à desospitalização ou 'humanização' da atenção ao paciente psiquiátrico; outras vezes se confunde com a antipsiquiatria. Não há uma clareza no âmbito institucional sobre tais princípios e sobre as estratégias do movimento antimanicomial.

Considerando as várias questões até aqui discutidas, podemos afirmar que se cria uma cisão entre o que diz respeito ao âmbito do institucional (o público) e ao âmbito individual ou da própria equipe (o privado). Ora a instituição é depositária de um ideal, ora é depositária de impedimentos (aquela que tolhe a expressão das subjetividades). Do ponto de vista do trabalhador; ora como se o trabalho pudesse ser realizado independentemente da instituição (sentimento de onipotência) e ora ele tendo a experiência do seu 'fracasso' na execução da tarefa (sentimento de impotência).

A oscilação entre relações de dependência $X$ independência pode ser compreendida como uma das formas de sobrevivência na instituição.

A oscilação entre relações de dependência $X$ independência pode ser compreendida como uma das formas de sobrevivência na instituição.

Um aspecto que merece ser destacado diz respeito à descontinuidade no desenvolvimento de trabalhos no âmbito das instituições públicas relacionado às constantes transformações institucionais que ocorrem devido a mudanças de equipes de governo. 
Freqüentemente, projetos que mal começam a ser implantados são interrompidos por causa dessas trocas. Assim, tanto passividade (dependência) quanto independência parecem dizer respeito a formas de defesa do trabalhador contra a própria desestruturação, pessoal e/ou profissional, num ambiente onde a única certeza é a de mudanças.

A: “... a sensação da proximidade do fim (da supervisão) ... isso também contribui para esse clima. (descontinuidade do espaço de supervisão)

$V$ : "E isso não é só na supervisão"

$R:$ “... tem todo um clima de final de gestão."

S: "Eu estou há 15 anos na prefeitura e nunca vi um final de feira, todo mundo quer fechar a sua barraca."

Q: "Houve movimentos muito grandes nesta gestão."

S: "Em termos da população, gerou muitas expectativas."

Q: "Eu acho essa questão complicada, essa questão da expectativa. Existem muitos furos nesta administração... É meio louco isso de mudança de gestão, de repente modifica tudo."

R: "É, e isso gera muita desmotivação."

$S:$ "É uma loucura."

$V:$ "A visão que eu tenho é diferente, acho que finalmente a gente entendeu o que eles queriam, conseguindo se mexer para colocar isso em prática."

R: "Fica algo de espera, no que isso vai dar, qual vai ser a nova diretriz."

$V$ : “... fico com a sensação de que algo vai abortar."

U: "Eu acho que vocês são muito assustadas. Eu sou aposentado. Entrei com o Jânio e saí com o Jânio. As mudanças de governo seguiram algo mais ou menos que estava planejado, só no governo do Maluf e do Reinaldo de Barros é que foi pior. Nesta administração houve uma descentração, dá uma maior importância para a comunidade... Na época do Prestes Maia era muito difícil. A administração do PT deu importância a todas as áreas de educação e saúde. Eu acho que a gente é muito resistente a mudanças."

S: "Eu falo do buraco do que faltou ser operado..."

U: "Tudo vai depender de quem está envolvido nessa área se mobilizar."

$\cdots$

A: "Isso a gente está tendo nessa gestão, briga pelo que a gente quer... Dentro dessa própria gestão há algo de estar mudando ... O que a gente levantou de documentação não trouxe nada ... O problema é a gente saber uma diretriz... Atualmente eu estou mantendo as coisas que eu estou fazendo, mas não estou fazendo nada de novo".

U: "Mesmo sendo do próprio partido (o sucessor), não dá para ficar pensando de que vai haver uma continuidade” ... Cada governo lida de um jeito com a situação.”

S: "Você falou de não ficar apavorada mas a gente fica muito.."

U: "Mas eu acho que não é para se apavorar, é para ser encarado como algo normal, é lógico que existem mudanças..”.

S: "Eu continuo apavorada."

U: "Se você não roubou nada não é para se apavorar" 
Q: “Eu acho que sua fala é contraditória. Eu acho que mudanças são normais, mas no campo do ideológico é outra coisa, por exemplo, a questão da antipsiquiatria, da desativação dos manicômios, que no papel é muito interessante, mas na prática é bastante diferente. Se, por exemplo, ninguém mexe na questão do estatuto (do funcionalismo público) as coisas não funcionam... A questão da burocracia é bastante complicada, é preciso dar uma maior autonomia para as regionais (de saúde) ... Há serviços que não podem ficar esperando o cara assumir ... Tem questões no funcionalismo que ninguém ataca, e isso me atrapalha bastante..”.

Ao final do governo, diante de perspectivas incertas relacionadas à mudança póseleitoral, diminui a representação de distância entre trabalhadores e ‘administração’. Apesar de críticas ao governo e da realização incompleta de projetos, reconhecem-se pontos positivos na atuação de ambos. Essa proximidade pode ser explicada em parte por haver nesse momento uma identificação dos trabalhadores com a administração: ambos estão impotentes diante da nova realidade. Paralisam-se as ações, ou seja, ao governo atual resta encerrar suas atividades e aos trabalhadores esperar as novas diretrizes.

Mas o distanciamento diminui apenas frente à equipe de governo e não em relação à estrutura institucional. Ao contrário, uma postura de passividade frente a tal estrutura é explicitada.

Centremos nossa atenção à última fala do trecho citado acima. São mencionadas questões referentes à necessidade de modificações no estatuto do funcionalismo público municipal. Estas dizem respeito a aspectos específicos dos direitos e deveres do trabalhador no contexto institucional. No entanto, a responsabilidade para tal mudança passa a ser atribuída a alguém que não se sabe 'quem é'. Desse modo, as modificações do processo são depositadas em 'mãos' distantes.

A postura de passividade desencadeia um efeito de ‘desresponsabilização’ desse mesmo possível sujeito transformador do processo. Neste sentido, corre-se o risco de se naturalizarem situações no cotidiano do trabalho que revelam um nível de violência instituído (por exemplo, ser natural o desmonte dos projetos a cada mudança de governo), muitas vezes determinante do sentimento de impotência e inutilidade. Desse modo, mais uma vez, a cultura manicomial reproduz-se nos serviços alternativos.

Se há, de um lado, essa 'auto-desresponsabilização' do trabalhador e a representação de serem 'naturais' as relações instituídas, por outro, contraditoriamente, o trabalhador também assume certa postura de independência, que também o distancia da instituição. Nesta, ele tem a ilusão de que quase nada interfere nos seus atendimentos: tudo o que acontece entre paciente e terapeuta não se relaciona ao contexto institucional, independentemente das mudanças constantes. 
“O vínculo terapeuta/paciente não muda com a administração, não adianta rótulo, o que vale é o que você faz quando está com o paciente.”

Esse tipo de relação 'independente' é permeado por representações que desvinculam a influência das transformações ocorridas num espaço mais amplo ('âmbito público’) das ações desenvolvidas por cada profissional ou pela equipe (‘âmbito privado’).

As modalidades de inserção no contexto institucional, marcadas por relações de dependência/independência e por representações ‘dicotomizadas' sobre o desenvolvimento das práticas (público/privado, técnico/político, individual/coletivo), são produzidas no cotidiano do trabalho, como formas de conter a angústia emergente, entre outras questões, do rompimento de fronteiras do modelo psiquiátrico tradicional a partir da proposição do modelo antimanicomial.

As cisões, a oscilação nas modalidades de inserção representam mecanismos de sobrevivência nesse novo contexto. São mecanismos psíquicos contra processos de mudanças. Lançando-se mão de antigas fórmulas de relacionamentos manicomiais, instala-se a paralisação do processo criativo das equipes de saúde mental. Nesse sentido, na consecução de novas práticas, reproduzem-se ‘velhas’ estruturas normalizadoras.

Mas se as contradições entre ‘velho’ e ‘novo’ modelo deixam os trabalhadores imersos num mundo de indiscriminações e atualiza a repetição de atitudes estereotipadas, elas também podem impulsioná-los à busca de novos rearranjos e de ruptura de comportamentos cristalizados. Nesse caso, os mecanismos psíquicos acima mencionados se instalam provisoriamente como recursos de intervenção, os quais, ao serem utilizados diminuem a angústia e permite que novos conteúdos emerjam, dando continuidade ao processo de elaboração. Reconhece-se então uma adaptação ativa à realidade, no sentido pichoniano.

Lembremos que segundo Bleger a parte indiferenciada (clivada) da personalidade ou do grupo fica depositada na estrutura institucional. As crises mais profundas instaladas no grupo são devido à ruptura dessa clivagem e à aparição dos níveis sincréticos (indiferenciados). Nesse sentido, a quebra das estruturas da instituição psiquiátrica tradicional, imprimida pelo modelo manicomial, causa um nível de desorganização grupal que se expressa na consecução da prática.

Consideramos que se, de um lado, tal desorganização pode gerar a paralisação no processo de criação, por outro, a inclusão de alguns aspectos até então clivados da vida social, podem produzir novas modalidades de interação e conseqüentemente uma possível reorganização das velhas estruturas. Respeitar a clivagem de um grupo significa “admitir essa segregação sancionada pela sociedade; significa admitir tanto os critérios normativos quanto os 
mecanismos pelos quais determinados sujeitos ficam doentes e acabam sendo segregados; é também admitir o critério adaptativo de saúde e de doença e a sua segregação como 'cura'.,218

Sob um ponto de vista da organização social é importante mencionar o risco que os trabalhadores correm ao buscar romper com a lógica manicomial de se transformarem em agentes de uma nova ordem. As instituições, no geral, articulam saberes e práticas específicas. Elas, ao mesmo tempo, "supõem um elemento sintetizador específico, sem o qual nenhum plano, nenhuma norma, nenhum conhecimento seria ativado, 'posto em ação'. Este elemento sintetizador é o agente institucional que concentra em sua cabeça e em sua atividade o desempenho das práticas, como delegado da instituição.”219

Eis aqui um paradoxo diante do qual os trabalhadores se encontram nas instituições: apesar de serem seus agentes precisam se colocar numa posição de romper/superar o papel que lhe foi delegado e produzir práticas contra-hegemônicas. Este é mais um problema relacionado aos 'limites’ da prática. A indagação constante e, simultaneamente, a construção de 'verdades provisórias' apresentam-se como atividades fundamentais no sentido de substituir as modalidades até então cristalizadas da cultura manicomial.

\footnotetext{
${ }^{218}$ BLEGER, J. Op. cit., 1991, p. 50.

${ }^{219}$ LUZ, M. T. História de uma marginalização: A política oficial de saúde mental . In: AMARANTE, P. Psiquiatria Social e Reforma Psiquiátrica. Rio de Janeiro. Editora FIOCRUZ, 1994, p.88/89.
} 
"Substituir práticas manicomiais" (ou suas expressões correlatas) é lema de centenas de trabalhadores em saúde mental no Brasil. A atuação política e técnica, a formulação de princípios e propostas, a concretização de práticas e os referenciais teórico-técnicos que fundamentam estas ações representam formas de contraposição ao tratamento destinado aos 'doentes mentais' proveniente da psiquiatria tradicional, cujas características de disciplinarização, normatização e exclusão são evidentes.

A psiquiatria, nascida em meio à ascendência e consolidação da burguesia como classe dominante, ao buscar alcançar seu estatuto de disciplina científica produz um discurso que gradualmente vai substituindo o dizer da loucura. Progressivamente vai normalizando e neutralizando o fenômeno da exclusão social. “A ideologia médica, ao definir a loucura como uma doença e ao difundir a imagem da doença como uma infelicidade que acontece por acaso e não como, na maioria dos casos, uma conseqüência de uma situação socio-económica bem definida, permite tirar às perturbações psicológicas e outros comportamentos desviantes, a sua dimensão social para as reduzir a uma problemática pessoal, privatizada, que apenas diz respeito à pessoa atingida."220

A nova disciplina desenvolve-se vinculada a exigências, contradições e lutas geradas pela sociedade capitalista. Para sobreviver às vicissitudes desta sociedade, a psiquiatria sofre transformações que vão se adaptando às ideologias de sustentação da classe dominante.

Com a industrialização crescente da sociedade, a estratégia psiquiátrica não se mostra eficaz, revelando-se um projeto ambíguo e contraditório: “os psiquiatras têm dificuldade em conciliar a função terapêutico-assistencial com a função carceral e repressiva das instituições; por outro lado, com a proletarização cada vez maior das massas trabalhadoras e consequente degradação das suas condições de vida, com o acentuar das desigualdades sociais, a fragmentação da família tradicional, o êxodo rural para a cidade a agudização das tensões provocadas pela luta de classes, a crise dos valores burgueses, os problemas sociais proliferam e adquirem características que escapam ao modelo médico tradicional. As instituições totalitárias

\footnotetext{
${ }^{220}$ FLEMING, M. Op. cit., p. 8.
} 
revelam-se inoperantes e a coerção física deixa de se justificar pois as descobertas medicamentosas permitem subsitituir progressivamente o 'colete de forças' pelo 'colete físico'. Assiste-se já nos finais do século XIX, nos países onde a economia capitalista está mais desenvolvida, a movimentos de liberalização das instituições psiquiátricas. A psiquiatria integra técnicas menos rígidas na base das quais se encontra a psicanálise que permitem alargar o seu âmbito de intervenção. Gradualmente, o poder psiquiátrico reforça-se e alia-se a outras instâncias jurídico-administratitvas., 221

Para Birman ${ }^{222}$, a história da psiquiatria tem sido uma repetição incansável dos fundamentos da razão alienista e de sua eterna ruptura com a barbárie da pré-históra da psiquiatria. "É entre a repetição do mesmo e o eterno retorno do antes que se teceram os fios onde se rearticulam as práticas e os discursos da história da psiquiatria.” Mesmo nos momentos fundamentais dessa história, em que a intenção de ruptura com o modelo inaugural do alienismo e pretensão de reforma existiam de fato, o discurso psiquiátrico não conseguiu produzir outro lugar para a loucura na tradição ocidental.

Desse modo, as formas de contraposição aos saberes e práticas da psiquiatria tradicional carregam também consigo ambigüidades e contradições e se expressam em diferentes âmbitos. Como vimos no decorrer do nosso trabalho, no que se refere a:

ש Instâncias governamentais do Estado

Proposições e discursos que se colocavam aparentemente na contracorrente da psiquiatria asilar se fizeram presentes nas estruturas governamentais em pleno regime de ditadura militar no Brasil.

Nesse período, ao mesmo tempo que, no Estado autoritário, vendia-se a imagem de bem-estar e progresso da sociedade brasileira, acentuava-se o processo de pauperização da grande maioria da população e a utilização do aparato repressivo com o intuito de calar as manifestações de denúncia e oposição ao regime.

Discursos e práticas contraditórias expressavam-se também no setor saúde. Apesar de no projeto de modernização do Estado estarem incluídos discursos relacionados à situação crítica da assistência psiquiátrica no país e ao reconhecimento da necessidade de reformas inspiradas no modelo comunitário americano, efetivava-se a ampliação e consolidação em larga escala do parque asilar.

A presença de discursos e algumas práticas, no âmbito das estruturas estatais, inspirados na psiquiatria preventiva americana, mostra-se contraditória com a política

\footnotetext{
${ }^{221}$ Ibidem, p. 9.

222 BIRMAN, J. A cidadania tresloucada. In: BEZERRA, JR., AMARANTE, P. (org.) Psiquiatria sem hospício; contribuições ao estudo da reforma psiquiátrica. Rio de Janeiro, Relume-Dumará, 1992, p.83.
} 
hegemônica de privatização que estava em curso. No entanto, este modelo preventivista não apresenta discordâncias com a essência do projeto político do Estado, assentado no modo capitalista de produção.

Por não estar em discordância fundamental com o projeto político do Estado autoritário, os discursos de reforma permanecem no âmbito governamental. Algumas propostas são colocadas em prática, mas de forma restrita a atividades setoriais, não trazendo, assim, mudanças significativas ao modelo de assistência psiquiátrica asilar.

bulatoriais inspiradas no modelo preventivista por parte de alguns setores governamentais, novas tendências vão se alojando nessas estruturas, resultando em algumas experiências inovadoras, já não mais sob a influência da psiquiatria comunitária americana.

Mais recentemente, a partir de 1989, com a posse de governos de esquerda e centro-esquerda em alguns municípios e estados brasileiros e sob influencia do movimento antimanicomial, formulações e propostas críticas ao saber psiquiátrico, ao modelo asilar, à política de privatização penetram no espaço institucional, trazendo avanços ao modelo de atenção em saúde mental. O aumento significativo de ações extra-hospitalares, a criação de novos equipamentos em saúde mental, a implantação do trabalho em equipe multiprofissional, entre outras ações, possibilitaram um real impacto na diminuição das internações psiquiátricas.

No entanto, o modelo hospitalocêntrico ainda permanece hegemônico em nosso país. Mesmo nos locais onde os avanços foram significativos, a cada mudança de governo, há um refluxo de propostas desinstitucionalizantes e os espaços são novamente tomados pela velha lógica manicomial.

\section{- Participação política no campo social}

A atuação política de denúncia contra as condições de tratamento aos doentes mentais e a reivindicação pela implantação de práticas substitutivas aos manicômios têm sua expressão maior entre trabalhadores em saúde mental que se organizam em movimentos sociais, partidos políticos, associações etc.

O Movimento de Trabalhadores em Saúde Mental é considerado o principal desencadeador do movimento pela reforma psiquiátrica brasileira. Nele se funda o exercício de reflexão crítica sobre saberes e práticas psiquiátricas.

Trabalhadores de diferentes locais articulam-se num espaço de luta não institucional, imprimindo um caráter não monolítico à organização do MTSM. A partir de vitórias obtidas no campo social e institucional, do avanço das formulações conceituais, da sensibilização e ampliação da participação de diferentes segmentos sociais, um novo momento se expressa nessa organização dando lugar ao Movimento de Luta Antimanicomial (MLA). 
O MLA produz uma crítica contundente aos manicômios - entendidos emblematicamente como expressão da estrutura presente nos diversos mecanismos de opressão da sociedade capitalista - e tem como meta a extinção dos hospícios, rejeitando estratégias voltadas para a humanização desta instituição. Entende que a extinção dos hospícios e a superação das relações manicomiais poderão se dar apenas com a transformação das relações de exploração da sociedade.

Mas, sabendo-se que a transformação da estrutura social não se dará a curto prazo e nem pela atuação de um movimento social isolado, torna-se necessário formular propostas e ter estratégias que permitam a reestruturação imediata do sistema de assistência psiquiátrica atual. Reformar e/ou transformar o sistema suscitam posições, estratégias e táticas diferenciadas, ambíguas e às vezes contraditórias dentro do movimento.

A complexidade da nova organização se acentua quando nos deparamos com a conjunção de diferentes setores sociais, principalmente usuários e seus familiares, participando do Movimento e não apenas os trabalhadores em saúde mental. As contradições inerentes a esse processo intensificam-se.

Apontamos que os movimentos sociais no geral não são monolíticos, mas processos abertos, sujeitos a contradições internas e pautados por uma composição heterogênea. Se, por um lado, os movimentos articulam-se em função de reivindicações coletivas e apresentam uma homogeneidade relacionada a carências comuns de seus membros, por outro, essa igualdade encobre a heterogeneidade dos bens, das capacidades, do tipo de trabalho ou dos recursos culturais que estes possuem.

No movimento antimanicomial, as diferenças que se manifestam, principalmente, entre trabalhadores (geralmente técnicos com formação universitária), usuários (geralmente expsiquiatrizados) e seus familiares, são marcantes. Aquilo que os une pode ser mobilizado por diferentes condições: os ‘doentes mentais’ sofrem os efeitos da exclusão; os familiares padecem pelos sofrimentos de seus entes; os trabalhadores, pela condição de tratamento que foge da ética profissional e social. As condições de vida, as histórias pessoais, os objetivos perseguidos e estratégias para atingi-los são heterogêneos e desencadeiam conflitos, expressos por posições e proposições diferenciadas. Se a obtenção de condições mais humanas de tratamento aos doentes mentais e a abolição dos limites da exclusão são objetivos comuns a todos, a aspiração por mudanças adquire contornos diferenciados.

Além disso, a convivência entre trabalhadores e usuários/familiares no âmbito do movimento se mostra ambígua. Muitas vezes atualizam-se as relações assimétricas e de dependência, tal como acontece nas instituições de saúde entre terapeuta e paciente, sendo predominante a posição dos trabalhadores em relação à forma de organização do movimento. Outras vezes estes técnicos, orientados pelo princípio da não exclusão e pela crítica aos padrões 
de normalidade vigente, valorizam o comportamento dos usuários, o qual não seria aceito se fosse manifestado por um 'não-usuário'.

Podemos dizer que, apesar dos avanços nos modelos de atenção em saúde mental, influenciados principalmente pela organização do MLA, as dúvidas e os conflitos, que se expressam no campo das relações intersubjetivas, são acentuados pelos próprios princípios antimanicomiais e pelas suas formulações teóricas ainda insuficientemente elaboradas.

- Unidades públicas de saúde/saúde mental

Nesse âmbito, as diferentes modalidades de ações em saúde mental se concretizam. Nele as ambigüidades, os conflitos e as contradições são acentuados: na prática institucional confluem trabalhadores, população (usuários dos serviços) e representantes da estrutura governamental.

O conjunto de trabalhadores apresenta aspirações, concepções, posições frente a manifestações coletivas e políticas muito diversas. A atuação deles varia da militância em partidos políticos, movimentos sociais, associações profissionais até a ausência total de qualquer manifestação coletiva. Poderíamos supor que o denominador comum na ação da grande maioria dos trabalhadores seria uma postura humanitária no trato aos doentes mentais, o que não significa necessariamente estar de acordo com os princípios do movimento antimanicomial.

A ‘substituição de práticas manicomiais’ pode encontrar diferentes sentidos, os quais vão da preservação das condições humanas do homem (as condições precárias do hospital psiquiátrico sensibiliza parte significativa dos profissionais que trabalham na área de saúde mental; desenvolver trabalho ético, de respeito à vida, de modo geral, faz parte dos ideais do exercício da profissão); à crítica ao aparato pseudo técnico-científico e o empenho em buscar novas possibilidades de lidar com o doente mental; até à crítica radical à estrutura social capitalista.

Os usuários dos serviços financiados pelo governo, por sua vez, são em grande maioria pertencentes à camada da população que possui poucos recursos materiais e financeiros. São mobilizados, por diferentes razões, a procurarem os serviços e têm idéias diversas sobre o local onde são atendidos, sobre os profissionais, as condições de saúde do país etc. Um denominador comum entre eles seria a condição de pobreza material a qual estão submetidos em nossa sociedade e a ‘condenação’ à utilização dos serviços públicos. Eles podem ser vistos como excluídos não somente por serem portadores de transtornos mentais, mas também pela sua condição de pobreza.

Deste modo, o serviço público tem sido destinado à população 'pobre’ e 'carente', característica esta determinante do tipo de organização do serviço e da inserção do trabalhador. A pobreza da população aliada à pobreza de recursos dos serviços exercem uma influência sobre 
a constituição da equipe de trabalho. A condição de pobreza do usuário parece carregar consigo a condição de pobreza dos serviços e da auto-imagem do trabalhador.

A identificação dos trabalhadores com seus próprios pacientes, doentes mentais e pobres é característica desse contexto. Trabalhador e usuário se confundem: aos pacientes, a precariedade de condições de vida, aos trabalhadores, a precariedade de formação e de condições de trabalho.

Sob o ponto de vista das políticas governamentais, o investimento no setor saúde, e de modo geral nos setores sociais, como vimos, não tem sido prioridade, a não ser por iniciativas de governos isolados em contextos históricos específicos.

O trabalho no serviço público, desse modo, tem sido desvalorizado e para muitos trabalhadores ele não é visto como opção, mas sim como complementar a outras funções que desempenham ou como lugar para adquirirem experiência profissional.

A imagem dos governantes perante os trabalhadores é também desvalorizada e está associada à incompetência, falta de vontade política, apropriação indevida dos bens públicos etc. As novas propostas e diretrizes governamentais na maioria das vezes não são benvindas pelos trabalhadores, principalmente pelo grau de desconfiança instalado entre ambos.

Entre trabalhadores e administradores freqüentemente surgem impasses, independentemente do partido político ou das intenções do governo. Os impasses institucionais, no entanto, não se restringem à relação administração X trabalhadores. Estão presentes também nas diversas relações (os trabalhadores entre si ou usuários entre si, trabalhadores X usuários) estabelecidas nas unidades de saúde .

Os conflitos, os impasses e a possibilidade de superá-los (ou não) no contexto das práticas, podem ser entendidos ainda sob a perspectiva dos mecanismos envolvidos na relação eu/outro (grupo), mediada pela instituição.

As instituições, entendidas como elementos da regulação social global, ao serem analisadas revelam um caráter paradoxal, sendo que a manifestação de contradições é inerente à sua constituição. Elas vivem sob a égide de uma ideologia igualitária, em que a cooperação dos iguais é apresentada como necessidade. Porém, essa necessidade é constantemente desmentida. Na relação entre os trabalhadores, por exemplo, “cada especialista pode sucumbir ao desejo de pensar que os progressos do paciente são devidos unicamente à técnica específica que utiliza, sendo que a ação dos outros apenas constitui um entrave.” ${ }^{223}$ Ciúme e rivalidade vão se manifestar no que diz respeito às concepções, posições políticas, utilização das técnicas, em quem tem melhor relação com o usuários (ou quem é o ‘proprietário’ do doente).

A instituição, segundo Enriquez, produz elementos característicos de sistemas fechados, os quais se expressam pela repetição de comportamentos; aumento da burocracia pela multiplicação de normas, procedimentos, convenções, que trazem como conseqüência ausência

$\overline{{ }^{223} \text { ENRIQUEZ, E. Op. cit., 1991, p. } 70}$ 
de iniciativa, necessidade de segurança, fuga de responsabilidades e também a habilidade para contornar regras e para preservação do funcionamento institucional.

Características de vida e morte são inerentes à instituição e se apresentam em constante relação de oposição. Uma organização viva é aquela que não sucumbe à desorganização e que pode "enfrentar os desafios internos e externos, acolher o sentido que circula nela e dar sentido ao que ela faz”. A mortífera é aquela que torna os comportamentos não hierarquizáveis, totalmente conflituais mas não tratáveis, ou que os transforma em a-conflituais e não significativos. Estas características instauram, nas organizações, um processo de decomposição, fruto do silêncio do desejo e do ódio de qualquer desejo. "Uma instituição de tratamento apresenta uma vulnerabilidade particular a esse processo, pois não pode subtrair-se à questão da vida e da morte psíquica ou física dos seus pacientes. Assim sendo, para ela é mais fácil sucumbir aos atrativos mortíferos que a constituem do que lutar contra a fascinação do nada."224

Sob a perspectiva de Bleger, as instituições são depositárias da parte indiferenciada (dos vínculos simbióticos primitivos) da personalidade. A dissolução ou tentativa de mudança das estruturas institucionais podem produzir uma desagregação psíquica dos seus membros.

Diante da mudança vive-se uma experiência de medo frente à novidade, ao desconhecido. Podemos dizer que há uma propensão na experiência institucional em se manter a estrutura atual, em repetir o conhecido das velhas estruturas. Desse modo, os efeitos da burocratização rondam os espaços voltados para construção de novas práticas. "Sabemos que uma das causas da burocratização é a de estabelecer uma tentativa de amortizar mudanças e de evitar ansiedades.” 225

As proposições de mudança da prática tradicional da assistência psiquiátrica, ao mesmo tempo que são 'desejadas' por uma grande parcela dos trabalhadores em saúde mental, carrega consigo as incertezas quanto ao seu significado. "Uma vez quebrada a instituição manicomial, as identidades se desfazem em cacos; não só a do paciente (como louco), mas também, as do psiquiatra e do enfermeiro. Quem é ele? Quais as funções daquele? Devolver o paciente à comunidade da qual é emergente é uma interpretação precisa, mas como realizála?’226

Para Bauleo, a abolição do manicômio envolve outras situações além do lugar do estabelecimento da prática psiquiátrica. Seria necessário uma explicitação das ansiedades despertadas no grupo social diante das defesas coletivas estruturadas em função do doente mental. "O sistema de defesas coletivas que encontrava sua emblemática concretização

\footnotetext{
${ }^{224}$ Ibidem, p. 72 e 73.

${ }^{225}$ BAULEO, A. Op. cit., 1988, p.34.

${ }^{226}$ Ibidem, p. 8.
} 
arquitetônica no hospital psiquiátrico cambaleia e pode desaparecer, liberando assim, aquilo que no plano da realidade e das fantasias sociais havia absorvido e entranhado.”227

Enfim, a 'substituição de práticas manicomiais' apresenta-se como uma tarefa extremamente complexa. Tarefa esta que carrega consigo contradições inerentes ao sistema social da qual advém e, conseqüentemente, às concepções e formulações teórico-técnicas, às diretrizes políticas e técnicas definidoras da organização institucional, à natureza das instituições públicas de saúde na sociedade brasileira, às forças políticas envolvidas com tal questão etc., assumindo, assim, significações diversas no conjunto dos sujeitos nela envolvidos.

Para responder às indagações colocadas inicialmente neste trabalho, devemos considerar tal complexidade, entendendo que o discurso sobre a loucura, e as formas de 'intervenção' sobre ela, é emblemático das contradições inerentes à constituição da psiquiatria, dos princípios antimanicomiais e da própria estrutura social. Nesse sentido, a assimilação, a interpretação, a recriação ou mesmo a reprodução das idéias, fundamentos e ações envolvidos na construção de novas práticas em saúde mental, por parte dos trabalhadores, carregam essas mesmas contradições, as quais se manifestam nas relações intersubjetivas, mediada pela angústia inerente a estas relações.

A atividade criativa no trabalho, relacionada a processos de ressignificação, apresenta-se como condição essencial para superação das antigas em novas práticas e, ao mesmo tempo, para a transformação dos próprios sujeitos nelas envolvidos. Tal atividade diz respeito à disponibilidade para enfrentar e superar conflitos advindos das contradições do modelo e impasses instalados nas relações intersubjetivas. O espírito do novo, a aplicação, a descoberta, a invenção como produto do trabalho em equipe implicam uma plasticidade na convivência grupal, condição para superação de relações cristalizadas, estereotipadas e burocratizadas.

Examinemos mais de perto, direcionando nosso olhar sobre o âmbito das práticas desenvolvidas nas unidades de saúde.

Pudemos constatar a existência de uma grande diversidade de conflitos, entre os trabalhadores, referida a suas concepções teóricas, formação, posição política, tipo de envolvimento com o serviço público etc. No entanto, a angústia emergente nesse contexto é comum a todos. Uma clareza das propostas e dos princípios antimanicomiais, uma formação mais sólida e o domínio de um instrumental para o trabalho, são necessários e podem propiciar maior grau de discernimento relacionados às dúvidas emergentes no universo de trabalho. Porém, as angústias decorrentes da convivência e das novas propostas, muitas vezes embasadas por fundamentos insuficientemente elaborados e/ou confliltuosos, são inevitáveis.

${ }^{227}$ Ibidem, p. 15. 
Como já dissemos, apesar da complexidade, das contradições e de tantos entraves na consecução da nova tarefa, os avanços no trato ao 'doente mental', fruto também da atividade criativa dos trabalhadores, foram visíveis na implantação da rede substitutiva paulistana. Estes avanços puderam ser verificados pelos dados estatísticos, pelos relatos nos grupos de supervisão e também pelas experiências que tivemos junto aos trabalhadores em saúde mental e movimentos sociais.

Vários foram os casos de 'doentes mentais’ egressos de hospitais psiquiátricos, após muitos anos de internação (em alguns casos, ultrapassavam vinte anos), que passaram a conviver com suas famílias e a obter apoio das novas estruturas institucionais de saúde. Os passeios em parques, as visitas a museus, exposições, a ida a cinemas e shows, as festas e comemorações realizadas nos próprios equipamentos demonstravam a possibilidade de construção de um novo tipo de convivência que em nada lembra o 'institucionalismo' das organizações fechadas.

Tais experiências, apesar de valorizadas pelos próprios trabalhadores, provocam tensões, às vezes relacionadas ao medo de perder o controle sobre o comportamento de seus 'pacientes', ou pela repercussão que esses mesmos comportamentos têm, diante da população considerada 'normal'. Pudemos, por exemplo, presenciar uma sessão de cinema aberta aos profissionais, usuários e familiares das instituições de saúde mental, por ocasião das comemorações do 'Dia 18 de maio'. A preocupação dos profissionais relacionadas ao tipo de atitude que os usuários teriam ('será que vão ficar quietos durante a sessão?'), ou às bolsas carregadas de psicotrópicos ('caso alguém entrar em surto’), demostram as tensões vividas pelos trabalhadores, apesar dos efeitos positivos das ações desenvolvidas. Experiências bem sucedidas não implicam ausência de problemas, angústias e conflitos.

A superação da angústia, como parte do processo de trabalho, está presente na atividade criativa dos profissionais. No entanto, quando ela é intensificada pode obstaculizar qualquer possibilidade de superação. Neste caso, a tensão e o medo resultam em grande sofrimento para a equipe de trabalhadores, podendo, dessa forma, reproduzir os princípios manicomiais que se quer superar.

Considerando que as contradições colocadas entre modelo psiquiátrico tradicional e modelo antimanicomial, a tendência à burocratização das instituições e a conversão de novas práticas a velhas estruturas, insistem em se manifestar no campo de trabalho e também considerando que, nesse contexto, a subjetividade dos envolvidos nas ações de saúde mental é matéria prima do próprio trabalho, buscamos destrinchar, principalmente, os conflitos - de natureza objetiva e/ou subjetiva, determinantes da paralisação do processo criativo no contexto de trabalho.

Questões relacionadas à concepção de loucura no novo trato à doença mental, à constituição da equipe multiprofissional e à formação, destacaram-se na construção de novas 
práticas inspiradas nos princípios antimanicomiais. A oposição conflituosa entre saberes e práticas do antigo e novo modelo se expressaram por contradições que dizem respeito ao que vem a ser 'loucura/doença x saúde mental', 'loucura/desrazão X razão', ‘anormalidade/ patologia x normalidade', 'saber $\mathrm{X}$ não saber', 'modelo médico $\mathrm{X}$ não médico', 'terapêutico $\mathrm{X}$ não terapêutico'. A quebra dos limites da instituição manicomial coloca em questão a construção/superação de limites conceituais, práticos, de relacionamento etc. Desta quebra à busca de ressignificação e de demarcação de novas fronteiras, um espaço de caos se instala. A indiscriminação, a confusão, a angústia invadem o cotidiano de trabalho.

Concepções advindas do movimento antimanicomial e das diretrizes políticas, as quais fundamentaram a implantação da rede substitutiva, acerca do processo saúde/doença, são ilustrativas do tipo de indiscriminação muitas vezes emergentes no processo de trabalho.

Nestas formulações, a concepção sobre as causas da 'doença mental' é radicalmente oposta à concepção clássica organicista. A determinação social no processo saúdedoença é enfatizada, não sendo abordadas outras possíveis ‘causas’ no processo de adoecer.

Deve-se considerar que um dos grandes méritos da psiquiatria atual foi exatamente revelar os fundamentos ideológicos da psiquiatria clássica, de denunciar a utilização de categorias oriundas da relação normalidade $\mathrm{x}$ anormalidade e a transformação destas em categorias que justificam a exclusão: 'sãos x não sãos', 'saúde mental x doença', 'razão x desrazão’. No âmbito das práticas, a oposição ‘doença biológica x doença social’ traz, por um lado, o mérito de buscar libertar os ditos insanos, excluídos do universo dos 'bens' sociais e da convivência (e estes não são apenas os doentes mentais, mas os portadores de deficiências, os homossexuais, prostitutas, os pobres), do pesado fardo, ao carregarem os males da sociedade em suas costas.

Porém, feita esta distinção, dúvidas se expressam quanto ao tipo de sofrimento que deve e pode ser 'tratado'. A origem desse sofrimento advém das mais diferentes causas, podendo em alguns casos, ser orgânicas (lembremos a grande dificuldade em discriminar a deficiência mental e a psicose, por exemplo). Indagações relativas ao 'como' e ao 'o quê' diagnosticar, preocupações em 'não rotular', explicitam questões relacionadas ao limite entre saúde $\mathrm{X}$ doença, entre os novos e antigos referenciais e instrumentais técnicos.

A noção de limite apresenta-se como fundamental e podemos atribuir a ela um duplo sentido. Pode ser entendida como limitação, de natureza externa e/ou interna, cuja manifestação obstaculiza a implantação das práticas (recursos destinados às políticas sociais, condição de pobreza da população e de precariedade no trabalho, insuficiência teórico-técnica, formação etc.) e também como fronteira, de natureza externa e/ou interna, associada à reconstrução do esquema referencial que se desfez na quebra de mitos, ideologias e verdades instituídas pelo modelo manicomial. 
A noção de limite carrega ainda, ao mesmo tempo, uma conotação negativa, significando as barreiras que impedem a convivência dos 'diferentes' (exclusão dos 'doentes mentais’, por exemplo) e uma conotação positiva, pois a delimitação de fronteiras pode possibilitar a organização do caos que freqüentemente emerge da indiscriminação. Esse duplo sentido, implica questões dilemáticas colocadas nas práticas voltadas para a superação dos manicômios, já que representa, ao mesmo tempo, cerceamento e exclusão e possibilidade de estruturação. Coloca-se em questão a construção de novas delimitações e ressignificações na construção dos princípios e práticas antimanicomiais.

As relações no trabalho são permeadas por indagações e pela necessidade de ressignificar as fronteiras estabelecidas entre usuário $\mathrm{X}$ trabalhador, psicose $\mathrm{X}$ neurose, espaço formal $X$ espaço informal, eficiência $X$ ineficiência de técnicas e procedimentos de atendimentos, público $\mathrm{X}$ privado, profissional técnico $\mathrm{X}$ profissional não-técnico, trabalhador $\mathrm{X}$ instituição, instituição de saúde $\mathrm{X}$ sociedade global.

A oscilação entre sentimentos de impotência $X$ onipotência e da relação de dependência $X$ independência (a equipe de trabalho, supervisores e instituição) ora se manifesta como ousadia criativa, ora como impeditiva de qualquer ação institucional. Sentimentos de inutilidade do trabalho são despertados e se associam à crença de inutilidade dos 'doentes mentais’, usuários dos serviços.

A experiência de 'não saber' pode ser tomada como fio condutor de análise. Ela resulta, como vimos, principalmente das indiscriminações que se manifestam na construção de novas práticas, as quais são acentuadas pelo tipo de formação dos profissionais envolvidos nessa tarefa. O surgimento de dúvidas, quanto à utilização do referencial técnico oriundo de áreas específicas do saber e quanto à validade destes referenciais para o 'bom' desempenho profissional, coloca a identidade profissional do trabalhador sob suspeita, levando à burocratização das funções institucionais.

A identidade profissional sob suspeita coloca também em dúvida a possibilidade de constituição da equipe multiprofissional: a heterogeneidade de seus membros, embora represente a possibilidade da construção do novo na convivência da diferença, torna-se um obstáculo. A equipe, uma das estratégias de ruptura do modelo e do saber médico, corre o risco de não se efetivar.

A experiência de 'não saber', associada à perda/busca de identidade, e, conseqüentemente, à necessidade de referenciais seguros para realização da tarefa, implica, vez ou outra, na busca da prática psiquiátrica como ‘tábua de salvação’ para o caos da indefinição. No retorno às práticas conhecidas, delega-se, mais uma vez, o lugar de hegemonia ao saber do psiquiatra. Ao mesmo tempo que se tenta romper/superar saberes e práticas do modelo médico, este pode se apresentar, muitas vezes, como elo estruturante da equipe. Nesses momentos, a 
equipe pode vislumbrar a possibilidade de fortalecer seus laços de coesão: as limitações da prática e as indefinições podem ser reveladas e o poder de desestruturação perde seu impacto.

Assim, as formas de 'contemporizar' os conflitos emergentes da heterogeneidade da equipe assumem formas diferenciadas: busca-se a eliminação dessas diferenças, a partir do abandono da especificidade profissional; ou, no pólo oposto, instala-se a hierarquia de uma das categorias profissionais.

De outro lado, a coesão se manifesta quando a equipe de saúde mental se opõe (cisão) aos demais trabalhadores da unidade de saúde. Vez ou outra, conflitos se manifestam pela cisão entre profissionais com formação universitária, os ‘técnicos’, e os 'não técnicos'.

Os 'não técnicos' identificam-se e são identificados, pelos 'técnicos', com os usuários, seja pela semelhança das condições de vida, seja pela ambigüidade do lugar que ocupam na instituição (são trabalhadores e também usuários). Essa cisão representa uma das formas dos 'técnicos' romperem provisoriamente a identificação com os usuários e sua loucura, a qual acentua sua perda de identidade e de inutilidade profissional. Nesse rompimento, assumem temporariamente um lugar de saber e de imunidade aos efeitos da loucura.

O lugar de 'saber' deve ser resgatado ou adquirido, como possibilidade de construir os limites perdidos na construção de práticas antimanicomiais. As expectativas, como vimos, são depositadas, com freqüência, em diferentes modalidades de formação, destacando a supervisão clínica e/ou institucional.

Porém, as expectativas nela depositadas - de conjugar e responder a grande parte das necessidades geradas na implantação da rede - transcendem suas possibilidades como mecanismo de formação. Espera-se, desse modo, que a supervisão possa suprir deficiências da formação universitária e incluir questões relacionadas ao novo trato à doença mental; integrar, organizar e definir os papéis dos serviços e profissionais dentro da equipe; sanar problemas de relacionamentos da equipe e da própria instituição; propiciar uma experiência de troca de conhecimentos, de vivências, de práticas intra/inter equipes e também interinstitucional.

Com tantas expectativas transcendendo os limites desse dispositivo, trata-se também agora de delimitar seus objetivos e suas possibilidades de alcance. Caso contrário, as indiscriminações relacionadas a esta prática fundem-se às tantas outras instaladas no cotidiano de trabalho, fortalecendo a construção de espaços privados, os quais criam a ilusão da independência das ações dos trabalhadores em relação à instituição.

Da relação estabelecida entre os trabalhadores e o espaço de supervisão, podemos depreender dois tipos de modalidade de inserção institucional destes mesmos trabalhadores, os quais oscilam entre a aderência (dependência) e a recusa (independência) das ofertas institucionais. A alternância entre dependência X independência configura, em ambos os casos, uma postura de distanciamento em relação à instituição: ou se responsabiliza a estrutura institucional ou a si próprios pelo ‘fracasso’ das ações. 
Considerando os conflitos e contradições, acima discutidos, mecanismos de sobrevivência são desenvolvidos no contexto institucional. As cisões entre os diferentes sujeitos envolvidos na prática, a homogeneização ou hierarquização dos papéis na equipe, a criação de um espaço privado e o distanciamento/cisão em relação à instituição, a idealização do saber e depositação em algumas estruturas ou categorias profissionais são algumas das formas de sobrevivência contra a própria desestruturação pessoal e/ou profissional desenvolvidas na construção das práticas substitutivas.

Tais mecanismos têm a finalidade de destruir as fontes de ansiedade embutidas em todo o processo de mudanças. Para Pichon-Rivière, "a mudança implica perda, gera - até que se institucionalize - graves sentimentos de insegurança, que provocam ou aumentam o isolamento e a solidão, fundamentalmente pela perda do sentimento de pertença a um grupo social estabilizado. O outro medo que coexiste é o medo do ataque, que aparece pelo fato de o indivíduo ter saído de seu estereótipo anterior e não se ter instrumentado o suficiente para se defender dos perigos que acredita incluídos no novo campo. Esse conflito tão grave em nossa cultura leva-nos à imobilidade e à marginalidade.” 228

A tarefa atribuída aos trabalhadores, a estrutura grupal e o contexto de trabalho, no qual se relacionam tarefa e grupo, numa linguagem pichoniana, constituem uma equação da qual surgem fantasias inconscientes. Entre estas “algumas podem funcionar como obstáculo na abordagem do objeto de conhecimento e como deformantes na leitura da realidade, enquanto que outras atuam como incentivo do trabalho grupal.” 229

À medida que o sujeito apreende esse objeto de conhecimento e o transforma, ele modifica-se a si mesmo, entrando, assim, em um "interjogo dialético com o mundo". ${ }^{230}$ Configura-se o processo de adaptação ativa à realidade, tal como é entendido por PichonRivière.

Deste modo, ao mesmo tempo que os mecanismos de sobrevivência, desenvolvidos no contexto institucional, são impeditivos da construção de novas práticas, podem representar também formas de 'adaptação ativa à realidade' e se configurarem como possibilidades de os trabalhadores resistirem às adversidades que são desafiados a enfrentar.

Romper/superar práticas sedimentadas há várias décadas, sem se transformar em agentes de uma nova ordem é o grande desafio na implantação de práticas substitutivas. Do mesmo modo, poder se deparar com as dificuldades de inserção nesse empreendimento é de fundamental importância para o acúmulo de forças que possibilitem a criação de uma corrente substitutiva.

É necessário lembrar que, em determinados momentos dessa construção, muito pouco pode ser refletido acerca das dificuldades oriundas das limitações conceituais, ou das

\footnotetext{
${ }^{228}$ PICHON-RIVIÈRE, E. Op. cit., 1986, p. 140.

${ }^{229}$ Ibidem, p. 116/117.
} 
modalidades de relacionamento institucional. Há períodos, como pudemos ver, em que os trabalhadores estão voltados para a obtenção de condições mínimas de trabalho e/ou de luta contra as posições conservadoras predominantes nas estruturas estatais. ${ }^{231}$

Podemos dizer que as contradições, as ambigüidades, as dúvidas referente à prática somente puderam emergir, durante a implantação da rede, porque as condições assim o permitiram. Consideramos que essas manifestações devem ser entendidas como características próprias de um momento de avanço na história das práticas em saúde mental e como características de tudo que está em movimento.

O sofrimento dos trabalhadores nesse momento dizia respeito às indefinições e indiscriminações no âmbito das práticas, as quais eram convidados a destrinchar, diferentemente dos momentos em que as ações voltam-se para reivindicações, denúncias e protesto. Desse modo, as dificuldades e as contradições decorrentes da prática devem ser registrados, problematizados para que possam ser, num outro momento, superados.

A formação do trabalhador em saúde mental, por exemplo, pode ser discutida, considerando aspectos até aqui delineados. As questões levantadas sobre os 'limites' da prática, e as indiscriminações nela geradas, e sobre os 'limites' dos referenciais conceituais apontam para a necessidade do registro, da problematização e da reflexão acerca dos conhecimentos provenientes de experiências e práticas em saúde mental desenvolvidas nos serviços públicos. O transitar entre estes conhecimentos e aqueles produzidos nas universidades, nas instituições de pesquisa e/ou formadoras inclui-se naquilo que emblematicamente é representado pela equipe multiprofissional: ‘convivência’ dos diferentes na construção de novas práticas e conhecimentos. A criação de laços mais estreitos entre a Universidade e as Instituições Públicas prestadoras de serviços representa um passo nesse sentido, podendo resultar em reformulações de políticas de formação, tanto nos cursos de graduação/especialização, quanto nos dispositivos de ensino (supervisão, cursos, seminários, palestras) freqüentemente desenvolvidos junto aos trabalhadores em saúde mental.

Sobre a possibilidade de avanço na construção de práticas antimanicomias, queremos enfatizar a importância do trabalho coletivo, no qual às dúvidas, aos impasses, aos conflitos, às contradições, à constituição de estratégias possa ser acrescentada a 'problematização' e o ato de interrogar. De acordo com Bauleo, consideramos que a interrogação

\footnotetext{
${ }^{230}$ Ibidem, p. 127.

${ }^{231}$ A rede substitutiva paulistana discutida neste trabalho foi desmantelada com a implantação do PAS, no ano de 1996. Entre 1993 e 1995 (governo de Paulo Maluf), os equipamentos mantiveram seu funcionamento, conservando na medida do possível as diretrizes antimanicomiais. Isto se deu, principalmente, graças ao empenho e investimento de uma parcela significativa de trabalhadores associada ao apoio de entidades e instituições, as quais se organizaram em torno do Fórum Paulistano Permanente de Saúde Mental, fundado no ano de 1993. Durante esses três anos, os trabalhadores estiveram mobilizados com questões relacionadas a garantir o funcionamento dos equipamentos da rede. Reflexões acerca dos princípios antimanicomiais nas ações de saúde mental, a constituição da equipe multiprofissional, as modalidades de relações estabelecidas entre os trabalhadores e destes com os usuários etc. foram deixadas num segundo plano, já que a possibilidade de fechamento das unidades era iminente.
} 
deve ser vista como um método, “já que ela possibilita o repensar e o refletir sobre certas problemáticas surgidas no trabalho cotidiano.” A interrogação ultrapassa o campo de trabalho e aparece mobilizando o afazer da equipe. ${ }^{232}$

Incluir esse método na construção das práticas torna-se um grande desafio, já que o indagar sobre princípios fundamentais que orientam práticas e ações políticas pode representar a emergência de novos problemas a serem superados. Podemos perguntar, por exemplo, quais significados são atribuídos ao conceito de 'diferença' e se seria possível instalar a convivência dos diferentes em nossa sociedade, sem se produzirem novas exclusões.

Afinal de contas a instalação de práticas antimanicomiais implica a impossibilidade de convivência com a velha lógica manicomial e suas teorias, técnicas e instrumentos. No campo político as posições estão bem delimitadas e se expressam em constante luta, onde, em alguns momentos desse processo, há espaço para apenas um vencedor.

No campo das práticas, as ideologias, o aparato técnico-científico e as posições políticas associadas estão arraigadas nos sujeitos/trabalhadores e de certa forma nos usuários. Quantos não são os profissionais que iludidos com suas técnicas, crêem estarem praticando o 'bem social', ou outros, que sem nenhuma ingenuidade fazem uso de seu poder, utilizando técnicas a serviço da exclusão (algumas destas são bem mais sutis do que as utilizadas na prática psiquiátrica tradicional; por exemplo, a condenação de tantas crianças ao espaço das classes especiais, por meio de laudos psicológicos)? Seria possível conviver com todas as diferentes posições políticas, ideológicas e técnicas na construção de novas práticas?

Com certeza a produção desses instrumentos mais sutis de exclusão não cabem na nova lógica. Posições antagônicas não convivem pacificamente: o velho deve ser superado ou a produção do novo não é atingida.

Centrando nossa atenção sobre os efeitos dessa diferenciação nos sujeitos/trabalhadores envolvidos na prática, perguntamos: quais as diferenças são passíveis de convivência e de possibilidade de construção do novo? Deve-se diferenciar, nessa construção, os profissionais que utilizam as técnicas ingenuamente daqueles que as reproduzem deliberadamente?

Isso nos remete à necessidade de melhor delimitar o que vem a ser a diferença, o que significa essa convivência e quais os sentidos possíveis nela embutidos.

Nós abordamos tal questão, neste trabalho, a partir de diferentes perspectivas. No âmbito político e ideológico, como oposição antagônica entre princípios, concepções, teorias embutidas no velho $\mathrm{X}$ novo modelo; no âmbito das relações sociais, como desigualdade, assentada nas representações de cunho social, como expressão da ideologia do normal e patológico, na qual se justifica a exclusão; e no âmbito das relações intersubjetivas como

${ }^{232}$ BAULEO, A. Op. cit., 1988, p. 27. 
estranho (Freud), a novidade e o desconhecido que se inclui no interior daquilo que é conhecido (Bleger) e heterogeneidade (Pichon-Rivière).

A exclusão, que se busca superar na construção de práticas antimanicomiais, estabelece-se a partir de condições históricas e socialmente determinadas, mas se reproduz, cristaliza-se e realimenta a ideologia da normalidade no âmbito das relações interpessoais. A circulação social de idéias que justificam a exclusão é determinante na constituição da subjetividade e imprime na relação com o outro, o medo do diferente, da loucura.

Esse medo, lembrando Bleger, é produzido diante do desconhecido que cada pessoa traz em si sob a forma indiferenciada do eu-sincrético e do medo de não continuar a reagir com as regras estabelecidas e assimiladas, o que pode implicar a dissolução da identidade estruturada pelos níveis integrados da personalidade. Sendo assim, a recusa em assimilar novas concepções, em incluir os excluídos no convívio social, muitas vezes, pode se cristalizar, inconsciente e/ou conscientemente, acentuando comportamentos estereotipados a serviço da manutenção da ideologia dominante.

Para Pichon-Rivière, “a heterogeneidade nos grupos dirige-se basicamente, para a ruptura dos estereótipos na modalidade de aproximação ao objeto de conhecimento, estereótipos que, por carência de confrontação, podem potencializar-se nos grupo homogêneos.” Segundo este autor, a "heterogeneidade de enfoques e contribuições deve conjugar-se, alterando-se funcionalmente, complementado-se, até chegar a uma integração ou construção enriquecida do objeto de estudo.” 233

Ao considerarmos o caráter interdisciplinar dos grupos, afirmamos que quanto maior a heterogeneidade dos seus membros, maior a homogeneidade da tarefa. No entanto, nem sempre a tarefa poderá ser única e homogênea. Quando as posições antagônicas, assumidas deliberadamente, são consolidadas, a cisão do grupo torna-se inevitável e as partes com posições opostas se excluem para a realização de diferentes tarefas. Tal cisão, nesse momento, representa uma saída para levar adiante os objetivos de cada um desses subgrupos.

A adesão de um ponto de vista antagônico a outro, a 'não-exclusão', não permitiria o deslanchar da tarefa. Poderíamos entender essa adesão, sob o ponto de vista psíquico, como a tentativa de instalação de uma totalidade narcísica em que todos devem ser iguais e, assim, não há como temer o diferente. Sob o ponto de vista político, ela representaria uma forma de conciliação, expressa por uma posição idealista, ingênua e a-crítica. A adesão, nesses casos, implicaria a homogeneização das diferenças, eliminando, ilusoriamente, a possibilidade de explicitação das contradições inerentes a essas relações.

Se 'eliminar diferenças' não se inclui entre os princípios antimanicomiais, e se superar mecanismos de exclusão e consolidar a convivência da diferença incluem-se entre seus ideais, há a exigência de explicitação sobre essas questões.

\footnotetext{
${ }^{233}$ PICHON-RIVIÈRE, E. Op. cit., p. 176.
} 
Indagar sobre o sentido de 'excluir a exclusão' (como mecanismo intra e intersubjetivo) da convivência social dos diferentes é uma questão a ser discutida, refletida, decifrada, delimitada, ressignificada e superada como tantas outras emergentes na complexa da tarefa que se impõe aos trabalhadores na construção de um novo modelo de atenção em saúde mental.

Nesse sentido, reafirmamos a importância sobre o método de interrogar. Ele permite que os novos conhecimentos (ou respostas provisórias, dadas coletivamente) estejam em contínua construção, podendo impedir sua cristalização e, desse modo, a instauração de novas verdades reprodutivas das mesmas estruturas que se tem buscado transformar.

Não devemos esquecer, contudo, que ações restritas ao campo das práticas, no âmbito dos pequenos grupos das instituições, não poderão por si só transformar a essência das relações manicomiais. “A desconstrução do manicômio implica necessariamente reinventar não só a psiquiatria mas - no limite - a própria sociedade em que vivemos.” 234

“Nessa onda está o drama, mas também a possibilidade de outro desfecho. Está o nó e a faca. O grito e o desafio. A morte, mas também a vida. No limite é que ocorrem os partos. Já passamos muitas vezes do limite. A vida está com pressa de nascer.”

(Betinho)

\footnotetext{
${ }^{234}$ BEZERRA JR, B. Cidadania e loucura: um paradoxo? In: BEZERRA JR, B., AMARANTE, P. (org.) Psiquiatria
} sem hospício; contribuições ao estudo da reforma psiquiátrica. Rio de Janeiro, Relume-Dumará, 1992, p. 113. 


\section{BIBLIOGRAFIA}

ALVES, D.S.N. et all. Elementos para uma análise da assistência em Saúde Mental no Brasil. Brasília, mimeo, 1992.

AMARAL, L. Espelho convexo: o corpo desviante no imaginário coletivo, pela voz da literatura infanto-juvenil. São Paulo, Tese (Doutorado), Instituto de Psicologia - USP, 1992.

AMARANTE, P. Análise dos determinantes e estratégias das políticas de Saúde Mental - O projeto da reforma Psiquiátrica (1970 - 1990) - Projeto de Pesquisa. NUPES/ENSP/FioCruz. Rio de Janeiro, mimeo, 1991.

Janeiro, SDE/ENP, 1995.

Novos Tempos em Saúde Mental. Saúde em Debate. CEBES, 37, 1992.

O homem e a serpente: outras histórias para a loucura e a psiquiatria. Rio de Janeiro, FIOCRUZ, 1996.

Psiquiatria Social e Reforma Psiquiátrica. Rio de Janeiro. Editora FIOCRUZ, 1994.

AMARANTE, P.; ANDRADE, P.H. As experiências antimanicomiais e a desinstitucionalização. In. Conjuntura e Saúde. NUPES/ENSP/FioCruz. Rio de Janeiro, agosto 1993.

BAREMBLITT G.F. Ato psicanalítico e ato político. Belo Horizonte, SEGRAC, 1987.

Grupos, teoria e técnica. Rio de Janeiro, Graal, 1982.

O inconsciente institucional. Petrópolis, Vozes, 1984.

BARROS, D. D. Jardins de Abel: desconstrução do manicômio de Trieste. São Paulo. EDUSP: Lemos Editorial, 1994.

BASAGLIA, F. A Instituição negada. Rio de Janeiro, Ed. Graal, 1985.

Psiquiatria alternativa: contra o pessimismo da razão, o otimismo da prática. São Paulo, Editora Brasil Debates, 1982.

BAUleO, A. Notas de Psicologia e Psiquiatria Social. São Paulo, Ed. Escuta, 1988.

Ideologia, grupo y familia. Buenos Aires, Busqueda, 1983.

Contrainstitucion y grupos. Madri, Fundamentos, 1977.

Problemas de la Psicologia Grupal (el grupo operativo-productivo). In Lo grupal, Buenos Aires, Busqueda, 1983. 
BEZERRA JR, B. Cidadania e loucura: um paradoxo? In: BEZERRA JR, B., AMARANTE, P. (org.) Psiquiatria sem hospício; contribuições ao estudo da reforma psiquiátrica. Rio de Janeiro, Relume-Dumará, 1992.

BEZERRA JR, B., AMARANTE, P. (org.) Psiquiatria sem hospício; contribuições ao estudo da reforma psiquiátrica. Rio de Janeiro, Relume-Dumará, 1992.

BION, W.R. Experiências en grupos. Buenos Aires, Paidos, 1972.

BIRMAN, J. A cidadania tresloucada. In: BEZERRA, JR., AMARANTE, P. (org.) Psiquiatria sem hospício; contribuições ao estudo da reforma psiquiátrica. Rio de Janeiro, RelumeDumará, 1992

BIRMAN, J.; COSTA, J.F. Organização de instituições para uma psiquiatria comunitária. In AMARANTE, P. Psiquiatria Social e Reforma Psiquiátrica. Rio de Janeiro. Editora FIOCRUZ, 1994.

BLEGER, J. Psico-higiene e psicologia institucional. Porto Alegre, Artes Médicas, 1984.

Simbiose e ambigüidade. Rio de Janeiro, Francisco Alves, 1988.

Temas de Psicologia. São Paulo, Ed. Martins Fontes, 1989.

BOteGA, N.; DALGALARRONDO, P. Saúde Mental no Hospital Geral. São Paulo, Ed. Hucitec, 1993.

BRASIL, Ministério da Saúde. Política Nacional da Saúde, Brasília, 1973; apud CEBES. Saúde em Debate, 10, São Paulo.

CAMPOS, G.W.S. A Saúde Pública e a defesa da vida. São Paulo, Ed. Hucitec, 1991.

Modelos de Atenção em Saúde Pública: um modo mutante de fazer saúde. Saúde em Debate. CEBES, 1997, 32 (16-19).

CAMPOS, L.F.L. Supervisão em psicologia clínica: critérios, condutas e modelos de supervisão. São Paulo. Tese (Doutorado), Instituto de Psicologia da USP, 1994.

CAPLAN, G. Princípios da psiquiatria preventiva. Rio de Janeiro, Zahar, 1989.

CARRANO, A. O canto dos malditos. Curitiba, Scientia et Labor, 1990.

CASTEL, R. A gestão dos riscos. Rio de Janeiro, Francisco Alves, 1987.

A ordem psiquiátrica - a idade de ouro do alienismo. Rio de Janeiro, Ed. Graal, 1978.

CEBES. A questão democrática na área da saúde. Revista Saúde em Debate, nº 9.

CHAUÍ, M. O que é ideologia. São Paulo, Brasiliense, 1984.

COIMBRA, M.B. Gerentes da ordem: algumas práticas “psi” nos anos 70 no Brasil. São Paulo. Tese (Doutorado), Instituto de Psicologia da USP, 1992.

COORDENADORES DO PROJETO HOSPITAL ABERTO. Hospital Aberto: Uma Síntese Possível. Cadernos CEFOR,, nº10, 1992.

COUTINHO, C. N. Representação de interesses, formulação de políticas e hegemonia. In TEIXEIRA, S.F. Reforma Sanitária - em busca de uma teoria. São Paulo, Ed. Cortez, 1989. 
CUNHA, M.C.P. Cidadelas da ordem - a doença mental na República. São Paulo, Ed. Brasiliense, 1990.

DAUD JR., N. Hospício no Brasil: a legitimação da violência. In Rev. Desbordar, n.5. Buenos Aires, 1992.

DELGADO, J. (Org.) A loucura na sala de jantar. São Paulo, Resenha, 1991.

DONNANGELO, M.C.F. Saúde e sociedade. São Paulo, Duas Cidades, 1979.

DURHAM, E.R. Movimentos sociais: a construção da cidadania. Novos Estudos, CEBRAP, São Paulo, 10, out. 84.

ENRIQUEZ, E. O trabalho da morte nas instituições. In A instituição e as instituições - estudos psicanalíticos. São Paulo, Casa do Psicólogo, 1991.

FARIA, M.C. Corpos estranhos, a imunologia entre Freud e Darwin. Ciência e Cultura, 1987.

FERNANDES, M.I.A. A população diante da implantação de programas políticos: efeitos da violência. In: CAMINO, L.; MENANDRO, P.R.M. (Org.) A sociedade na perspectiva da Psicologia: Questões teóricas e metodológicas. Rio de Janeiro, Associação Nacional de Pesquisa e Pós-Graduação em Psicologia - ANPEPP, 1996.

A subjetividade à luz de uma teoria de grupos. Psicologia USP/ Instituto de Psicologia, Universidade de São Paulo. - Vol. 1, nº 1 (1990). - São Paulo, USP-IP, 1990.

De Como Emerge a Questão do Narcisismo e da Alteridade no Grupo Operativo. São Paulo. Tese (Doutorado). Departamento de Psicologia Social e do Trabalho, Universidade de São Paulo, 1989.

FLEMING, M. Ideologias e práticas psiquiátricas. Porto, Afrontamento, 1976.

FOUCAULT, M. História da loucura. São Paulo, Ed. Perspectiva, 1989.

Microfísica do Poder. Rio de Janeiro, Ed. Graal, 1986

FRAYZE-PEREIRA, J.A. O que é Loucura. São Paulo, Ed. Brasiliense, 1985.

FREIRE COSTA, J. A história da psiquiatria no Brasil - um recorte ideológico. Rio de Janeiro, Ed. Xenon, 1989.

Psicanálise e contexto cultural: imaginário psicanalítico, grupos e psicoterapias. Rio de Janeiro, Campus, 1989.

FREITAG, B. Escola, Estado e sociedade. São Paulo, Moraes, 1980.

FREUD, S. Introducion al narcisismo (1914). In: Obras Completas, vol. 1, Madrid, Biblioteca Nueva, 1967.

Psicologia de las massas (1921). In: Obras Completas, vol. 1, Madrid, Biblioteca Nueva, 1967.

GERSCHMAN, S. A democracia inconclusa: um estudo da reforma sanitária brasileira. Rio de Janeiro, Ed. Fiocruz, 1995.

GOFFMAN, E. Estigma: notas sobre a manipulação da identidade deteriorada. Rio de Janeiro, Zahar, 1992. 
GOLDBERB, J. Clínica da Psicose: um projeto na rede pública. Rio de Janeiro, Ed. Te Corá, 1994.

GREEN, A. Sobre a loucura pessoal. Rio de Janeiro, Imago, 1988.

GRUPO DE SUPERVISORES. Sobre um Projeto de Formação na Rede Pública. São Paulo, Revista Percurso, São Paulo, 1989.

GUIRADO, M. Psicologia Institucional. São Paulo, E.P.U., 1987.

JACOBI, P. Movimentos sociais e políticas públicas. São Paulo, Cortez, 1993.

KAËS, R. A instituição e as instituições - Estudos psicanalíticos. São Paulo, Casa do Psicólogo, 1991.

KINOSHITA, R.T. et all Saúde Mental e cidadania. São Paulo, Ed. Mandacaru, 1987.

KOWARICK, L. Estratégias do planejamento social no Brasil. Caderno CEBRAP, São Paulo, 1971.

LANCETTI, A. et all Saúde e loucura 2. São Paulo, Ed. Hucitec, 1990.

LAPASSADE, G. Grupos, organizações e instituições. Rio de Janeiro, Francisco Alves, 1983.

LAPLANCHE, J.; PONTALIS, J.B. Vocabulário da psicanálise. São Paulo, Martins Fontes, 1988.

LEAVELL, H.R.; CLARK, E. Preventive medicine for the doctor in his community. New York, Mcgraw-Hill, 1965.

LEMA, V.Z. Conversaciones com Enrique Pichon-Rivière: sobre el arte y locura. Buenos Aires, Ediciones Cinco, 1985.

LEWIN, K. Problemas de dinâmica de grupo. São Paulo, Cultrix, 1978.

LOPES, C. Centros de Convivência e Cooperativa: Alternativas de Liberdade. In Revista Desbordar, 5, 1992.

LUZ, M.T. História de uma marginalização: A política oficial de saúde mental In: AMARANTE, P. Psiquiatria Social e Reforma Psiquiátrica. Rio de Janeiro. Editora FIOCRUZ, 1994.

MACHADO, R. et al. Danação da Norma: Medicina Social e constituição da psiquiatria no Brasil. Rio de Janeiro, Ed. Graal, 1978.

MACHADO DE ASSIS. O alienista. Ática, 1990.

MARX, K. Introdução. Contribuição à crítica da economia política. São Paulo, Martins Fontes, 1977.

Processo de trabalho e processo de valorização. In: O capital. Vol. I. São Paulo, Abril Cultural, 1983.

MELLO, S.L. Psicologia e profissão em São Paulo. São Paulo, Ática, 1975.

Trabalho e sobrevivência: mulheres do campo e da periferia. São Paulo, Ática, 1988.

MOFFAT, A. Psicoterapia do Oprimido, Cortez, 1983. 
MORATO, H.T.P. "Eu-Supervisão”: em cena uma ação buscando significado sentido. São Paulo. Tese (Doutorado), Instituto de Psicologia da USP, 1989.

MOTTA, R.M.M. Formação em serviço para profissionais de sáude: um programa em questão. São Paulo, Dissertação (Mestrado), PUC-SP, 1994.

PATTO, M.H.S. A produção do fracasso escolar: histórias de submissão e rebeldia. São Paulo, T.A. Queiroz, 1990.

T.A. Queiroz, 1984.

PELBART, P.P. Da Clausura do Fora ao Fora da Clausura. São Paulo, Ed. Brasiliense, 1989.

PESSOTTI, I. A loucura e as épocas. Rio de Janeiro, Ed. 34, 1994.

PICHON-RIVIÈRE, E. El concepto de porta-voz. In: Temas de Psicologia Social. 1978, 02, 11. Aires, Nueva Vision, 1977.

El processo creador: del psicoanalisis a la psicologia social. Buenos Vision, 1977. La psiquiatria, una nueva problemática. Buenos Aires, Ediciones Nueva O Processo Grupal. São Paulo, Ed. Martins Fontes, 1986.

Teoria do Vínculo. São Paulo, Ed.Martins Fontes, 1982.

PITTA-HOISEL, A.M. Sobre uma Política de Saúde Mental. São Paulo, Dissertação (Mestrado). Departamento de Medicina Preventiva, Universidade de São Paulo, 1984.

Hucitec, 1991.

Hospital: dor e morte como ofício. Saúde em Debate 34, São Paulo,

QUIROGA, A.P. Enfoques y perspectivas en Psicologia Social. Buenos Aires, Ediciones, 1986.

Processo de constitucion del mundo interno. Buenos Aires, Cinco, 1985.

ROCHA, L.C. A prisão dos pobres. São Paulo, Tese (Doutorado). Instituto de Psicologia da USP, 1994.

ROSA, A.C. Saúde Mental Comunitária: análise dialética de um movimento alternativo. São Paulo. Dissertação (Mestrado). Instituto de Psicologia da USP, 1987.

ROTELLI, F. Desinstitucionalização. São Paulo, HUCITEC, 1990.

SANTOS, E.M. Centro de Convivência e Cooperativa: um caminho em busca de uma perspectiva alternativa em saúde mental. São Paulo, Dissertação (Mestrado). Faculdade de Educação, Universidade de São Paulo, 1994.

SCHWARCZ, L.M. O espetáculo das raças. São Paulo, Companhia das Letras, 1993.

SOUZA, M.P.R. et all Psicólogos na Saúde e na Educação: A Busca de Novos Caminhos na Compreensão da Queixa Escolar. In CONCEIÇÃO, J.A.N. Saúde Escolar: a criança, a vida e a escola. São Paulo, Sarvier, 1994.

SPINK, M.J. et all Psicologia e saúde - repensando práticas. São Paulo, Ed. Hucitec, 1992.

TSU, T.A. A internação psiquiátrica e o drama das famílias. São Paulo, Vetor, 1993. 
TUNDIS, S.A.; COSTA, N.R. Cidadania e loucura - políticas de saúde mental no Brasil. Petrópolis, Ed. Vozes, 1990.

VASCONCELOS, E.M. Do hospício à comunidade. Belo Horizonte, SEGRAC, 1992.

VELHO, G. (org.) Desvio e divergência: uma crítica da patologia social. Rio de Janeiro, Zahar, 1989.

VILELA, A.M.J. Formar-se Psicólogo: Como Ser Livre como um Pássaro. São Paulo. Tese (Doutorado), Instituto de Psicologia da USP, 1996.

WESTPHAL, M, F. Participação Popular e Políticas Municipais de Saúde: Cotia e Vargem Grande Paulista. Tese (Livre Docência) - Departamento de Práticas de Saúde Pública da Faculdade de Saúde Pública da Universidade de São Paulo, 1992.

\section{DOCUMENTOS CONSULTADOS}

A Atenção à Saúde Mental no Município de São Paulo (1989 - 1986). Documento elaborado pelo Fórum Paulistano Permanente de Saúde Mental, 1995.

Avanços na concretização da Política Municipal de Saúde Mental do Governo Democrático e Popular da Cidade de São Paulo. Documento da Secretaria Municipal de Saúde, 1990.

Carta da ONU: A proteção de pessoas com enfermidade mental e a melhoria da assistência à Saúde Mental. 1991.

Carta do trabalhadores em saúde mental, lida no I Congresso de Trabalhadores de Saúde Mental do Estado de São Paulo, 1985.

Carta de Direitos dos Usuários e Familiares de Serviços de Saúde Mental. Santos, 1994.

Centros de Convivência e Cooperativas: Um ano e meio de história e prática. São Paulo, Secretaria Municipal de Saúde, 1992.

Convocatória para a Reunião Nacional da Luta Antimanicomial. Belo Horizonte, 1993.

Convocatória para Reunião Estadual da Luta Antimanicomial de São Paulo. MLA, 1993.

Declaração de Caracas. Proclamadas pela Conferência Regional para a Reestruturação da Atenção Psiquiátrica na América Latina no Contexto dos Sistemas Locais de Saúde, OPAS/OMS, 1990.

Esboço de Projeto nª 4: “Lares”. Prefeitura do município de São Paulo., 1989.

I Conferência Nacional de Saúde Mental - Relatório Final. Brasília, 1988.

Lei Orgânica do Município de São Paulo. Assembléia Municipal Constituinte, 1990.

Manifesto de Bauru, pronunciado no II Congresso de Trabalhadores em Saúde Mental, 1987.

Normas técnicas e padronização de condutas e parâmetros técnicos nas emergências psiquiátricas.

São Paulo, SMS- Assessoria de Saúde Mental, 1992

Normatização das ações de saúde mental nas UBS e Hospitais Dia em saúde mental municipais. Assessoria de Saúde Mental. São Paulo, SMS- Assessoria de Saúde Mental, 1992 
Normatização das ações de saúde mental nas UBS e Hospitais Dia em saúde mental municipais. São Paulo, SMS- Assessoria de Saúde Mental, 1992

O Partido dos Trabalhadores e a crise da Saúde Mental”. Documento produzido pelo PT-São Paulo, 1985.

O PT e a Crise de Saúde Mental. Documento produzido pelo grupo de saúde mental do PT - SP, 1984.

Orientações para funcionamento e supervisão dos serviços de saúde mental. Brasília, Centro de Documentação do Ministério da Saúde - Brasil, 1990.

Para Compreender a Atual Política Municipal de Saúde Mental do Governo Democrático e Popular da Cidade de São Paulo. Documento elaborado pela Assessoria de Saúde Mental SMS, 1989.

Participação e Controle Social no Sistema Único de Saúde. SMS-São Paulo, 1991.

Plano Municipal de Saúde. Prefeitura do município de São Paulo - SMS, 1989.

Programa de reorientação da assistência psiquiátrica. Brasília, Ministério da Previdência e Assistência Social, 1983.

Projeto de Formação Permanente de Recursos Humanos na Área de Saúde Mental. Convênio PMSP-SMS/PST-IPUSP, 1992.

Projeto de Lei $n^{\circ}$ 3657, de 1989 (Dep. Paulo Delgado), apresentado em 12/09/89 no Plenário da Câmara Federal.

Projeto de Supervisão Clínica e Institucional em Saúde Mental. CEFOR-SMS-SP, 1992.

Proposta de trabalho para equipes multiprofissionais em unidades básicas e em ambulatórios de Saúde Mental, in Arquivos da Coordenadoria da Saúde Mental do Estado de São Paulo, Vol. XLIII 1982/1983 n⿳亠口冋 especial.

Relatório da $1^{a}$ Reunião de Entidades de Familiares, Usuários e Ex-Pacientes Psiquiátricos. São Paulo, 1991.

Relatório das propostas elaboradas pelo Grupo de Trabalho para o enfrentamento das condições violentas de vida no município de São Paulo. SMS, 1991.

Relatório do Encontro Nacional da Luta Antimanicomial. Salvador, 1993.

Relatório da II Conferência Nacional de Saúde Mental - A reestruturação da Atenção em Saúde Mental no Brasil. Brasília, 1992.

Reorientação da Assistência à Saúde no âmbito da Previdência Social. Brasília, MPAS, 1983.

Saúde Informa Especial: CECCO - Centros de Convivência e Cooperativa. Comunicado interno da SMS-São Paulo, 1992.

SUS-São Paulo: A saúde no contexto da violência e da desigualdade social. Versão Preliminar para discussão, SMS-São Paulo, 1991. 